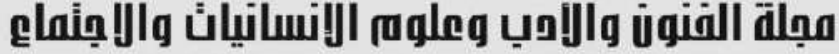

Journal of Arts, Literature, Humanities and Social Sciences www.jalhss.com

\section{الاسلوب الفني في أعمال الفنان خيري آدم}

\author{
أبر اهيم ياسين طه

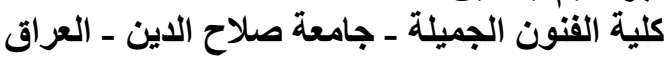 \\ البريد الإكتروني: ibrahim.yaseen@uor.edu.krd
}

يتعلق موضوع هذا البحث بـ ( الاسلوب الفني في أعمال الفنان خيري ادم ) و التعرف على طبيعة الاسلوب الفني الخاص المتبع لديه. ويعد اهمية موضوع البحث من الناحية الجمالية و الحسية والتقنية التي تم تجسيدها في لهي حركات وجوه والاجسام و الملابس ذات لمسة وطابع كوردي اصيل في اللوحات المرسومة بالمو اد الزيتية للفنان هذا و عن طريق مفهوم الاسلوب و السمات والصفات و الخصائص و التكنيك التي تتميز بها الاساليب الفنية المتفاوتة و المختلفة من خلال المراحل التاريخية لظهور الاسلوب الفني و التي تم فيه التطرق الى المظاهر و الدواعي التي أثرت على ظهور الاساليب الفنية عبر العصور التاريخية المختلفة ومن ثم التطرق أيضاً الىى موضوع المراءة وانوثتها وخَلُصنَ البحث الى جملة من النتائج كالآتي :تشكل المساحة المستطيلة (الافقية و العمودية )الثكل السمة الغالبة للوحات ومن ثم المساحات المربعة ،أضافةً الى غلبة استخدام الفنان الألوان

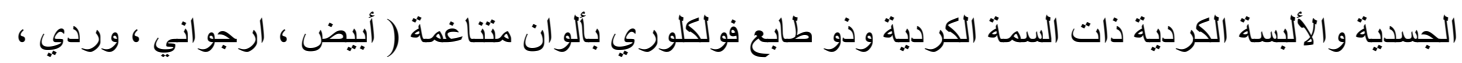

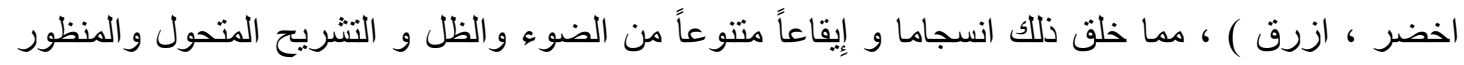

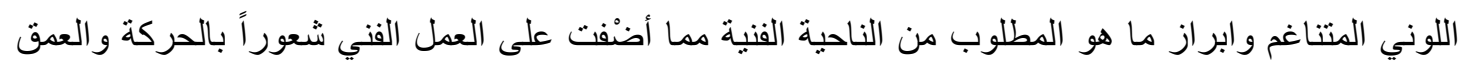

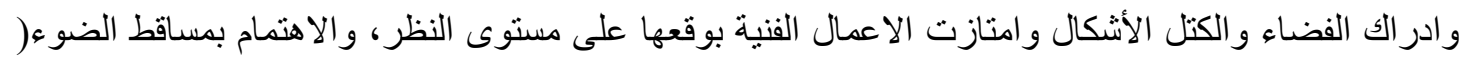
الطبيعية ، الاصطناعية) مما أعطى شعور اً بالكتل اللحمبة وبالكتلة بصورة عامة و كذلك تم تحديد الوقت و والمكان

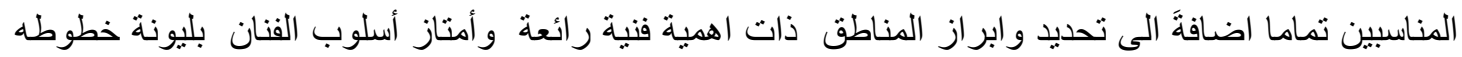
وصر امة اضوائه و انسيابيها القوية في تحديد الاشكال البارزة و العميقة وعلاقتها مع بعضها البعض و رسم

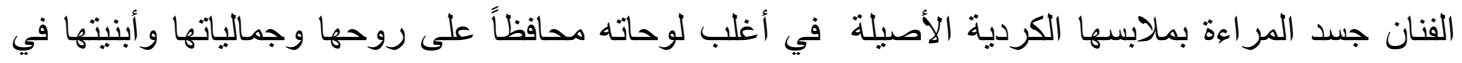
حركات ر ائعة في مو اقع مناسبة لها بأسلوب انطباعي معاصر في لوحات فنية نادرة الجمال و الرو عة. 


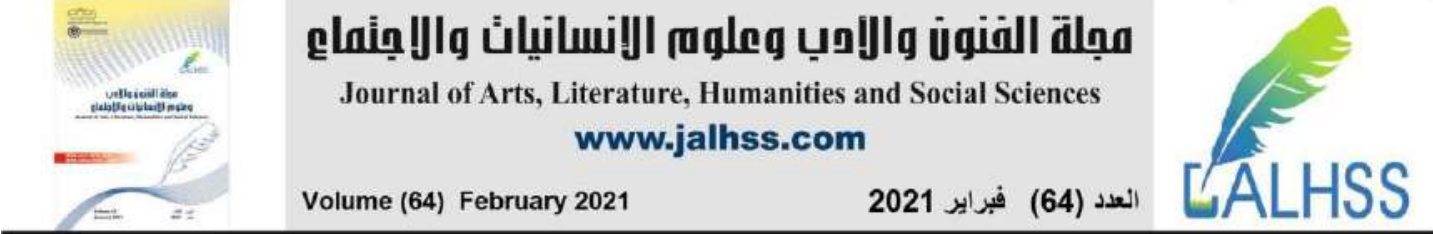 \\ The Artistic Style of the works "Khairy Adam's artist
}

\author{
Ibrahim Yassin Taha \\ College of Fine Arts - University of Salahaddin - Iraq \\ Email: ibrahim.yaseen@uor.edu.krd
}

\begin{abstract}
This research deals with (artistic style in the works of the artist Khairy Adam). It is an attempt to know the nature of his artistic style. The importance of the research is revealed in terms of aesthetics, sensuality and technology, which was embodied in the movements of faces and objects and clothes with a touch and Kurdish original character in drawn paintings with oil materials of the artist through the concept of style, characteristics, qualities, properties and techniques that are characterized by different technical methods and different through the historical stages for the emergence of the artistic style. The artist also touched on the manifestations and motives that influenced the emergence of technical methods through the various historical ages and then address the subject of woman and her femininity. The research has come up with a number of results as follows: the rectangular (horizontal and vertical) shape is of the dominant feature of the paintings and then the square spaces, in addition to the predominance of the artist's use of physical colors and Kurdish clothes with Kurdish and folkloric character in harmonious colors (white, purple, pink, green, blue), which create a varied harmony and rhythm of light and shade, shifting anatomy and the harmonious color perspective and highlighting what is technically required which gave the work a sense of movement and depth and perception of space and shapes blocks and the art works are characterized at the level of consideration and attention to light (natural, artificial) that gave a feeling of fleshy lumps and mass in general. Time and place were also identified exactly as well as the identification and highlighting areas of great artistic importance. The artist's style is characterized by soft lines and the severity of its light and strong flow in identifying the prominent and deep shapes and their relationship with each other. The artist painted the body of woman in her original Kurdish clothes in most of his paintings, preserving her spirit and aesthetics and buildings in wonderful movements in the appropriate positions to her in a contemporary impressionist style in rare artistic paintings of beauty and magnificence.
\end{abstract}

Keywords: Artistic Style, Khairy Adam. 


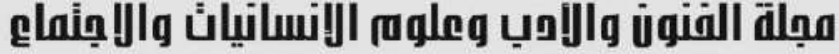

Journal of Arts, Literature, Humanities and Social Sciences www.jalhss.com

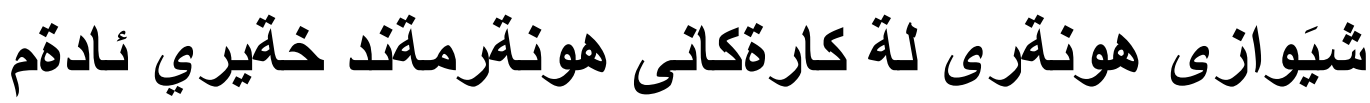

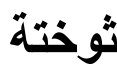

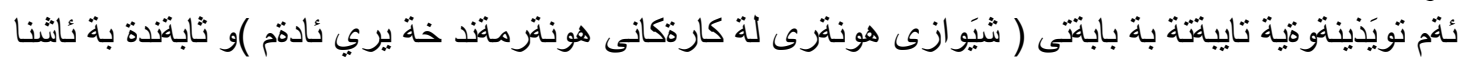

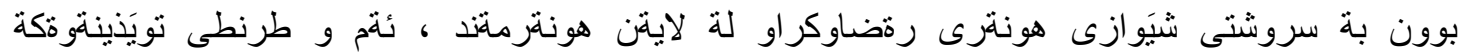

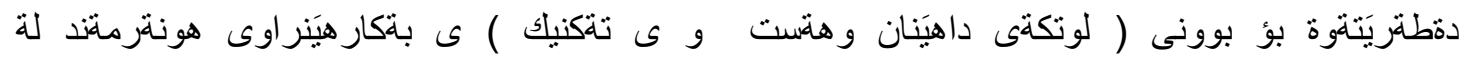

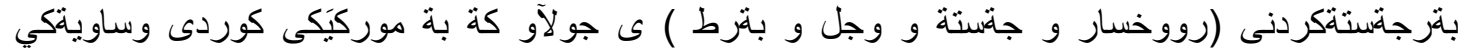

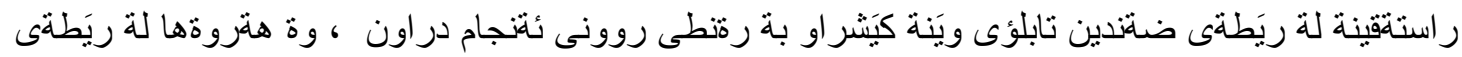

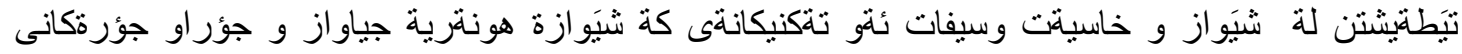

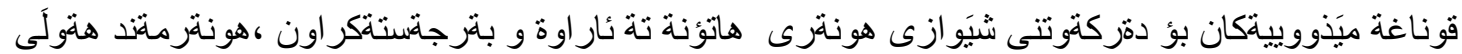

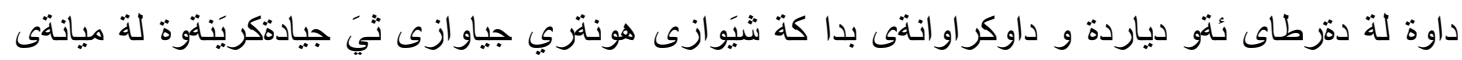

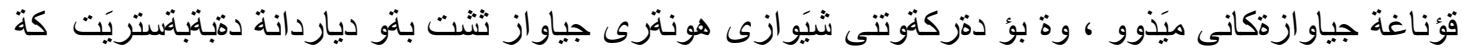

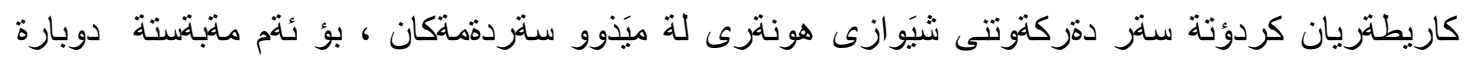

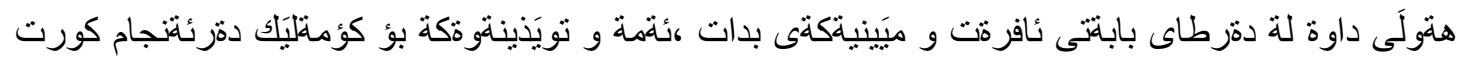

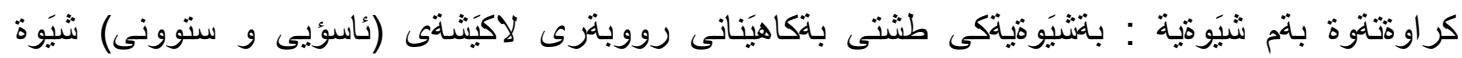

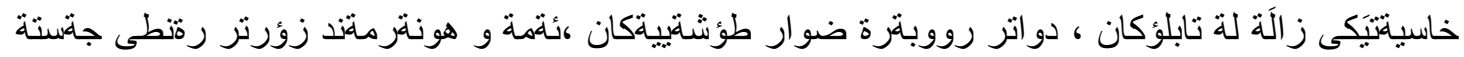

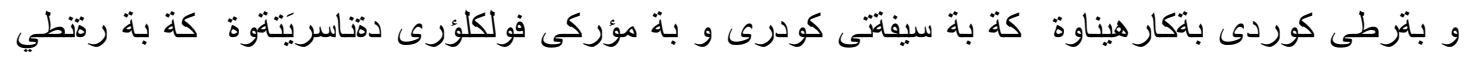

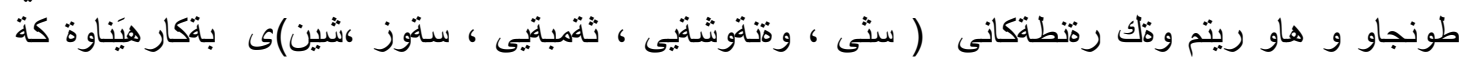

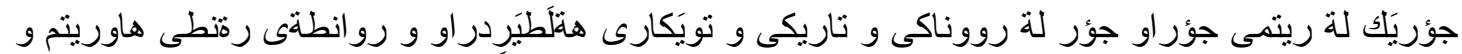

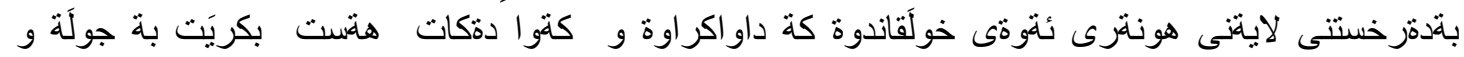

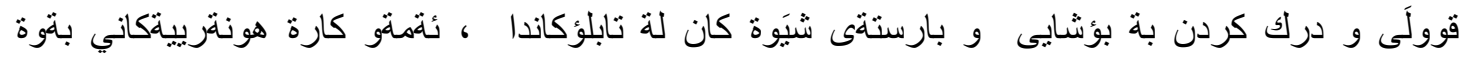

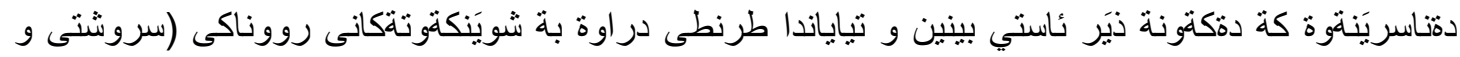

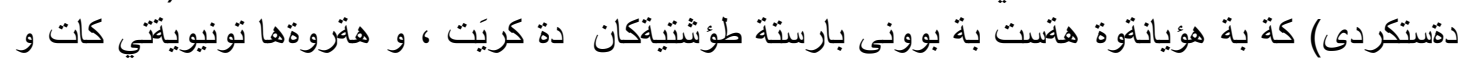

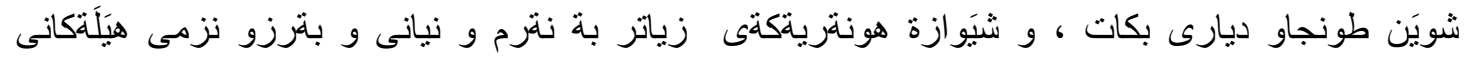

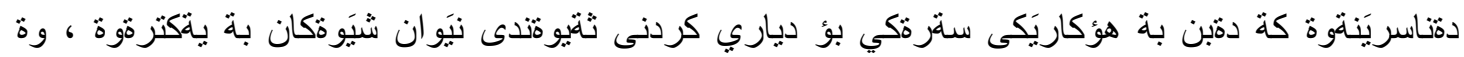

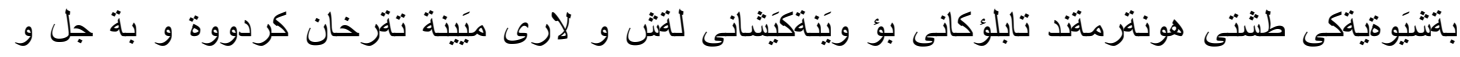

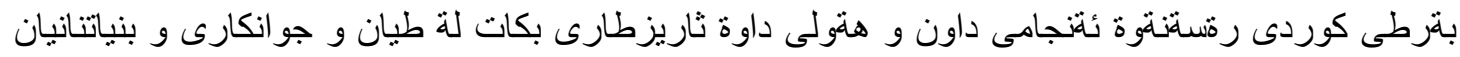

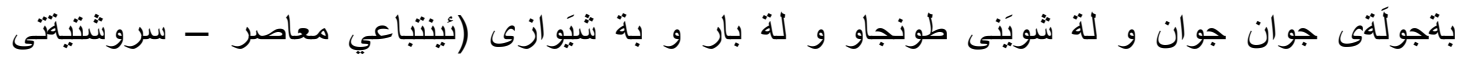

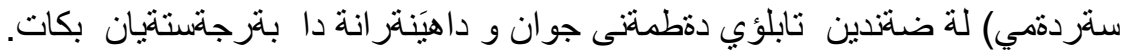




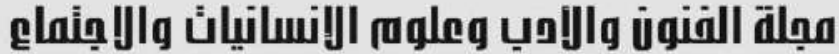

Journal of Arts, Literature, Humanities and Social Sciences www.jalhss.com

يهدف البحث الى التعرف على الأسلوب و الموضو عات التي تناولها الفنان والتقنيات التي أستخدمها والتعرف التهاف

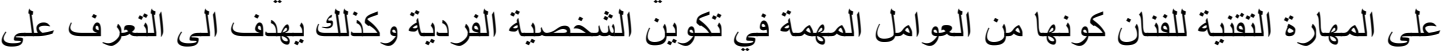

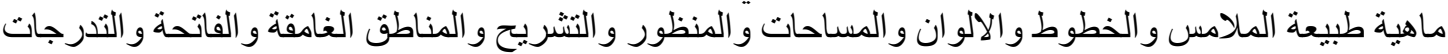

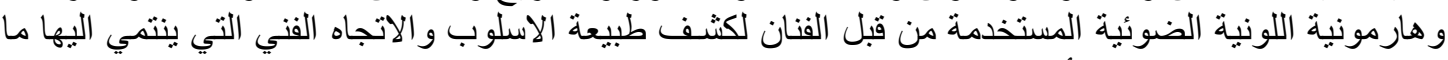

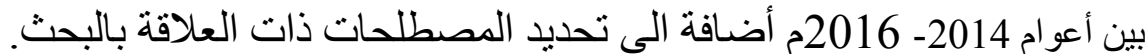
مراجعة الاعمال السابقة: لم يحصل الباحث على أية در اسة سابقة في هذا الصدد.

يتناول البحث (الاسلوب الفني في أعمال الفنان خيري ادم ) وموضوع البحثث يسلط الضوء الفئ على جملة تساؤ لات

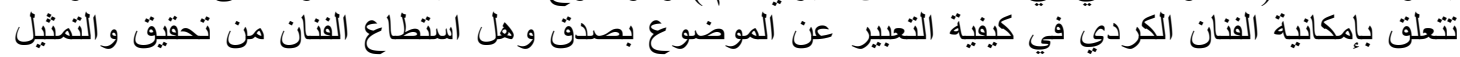

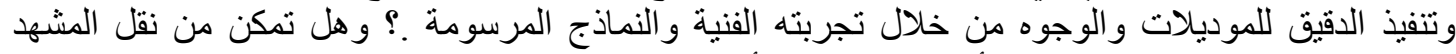

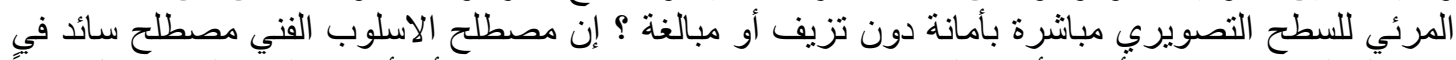

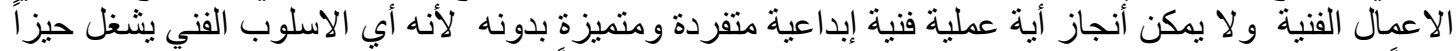

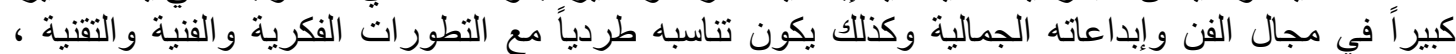

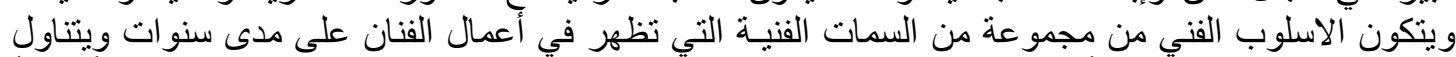

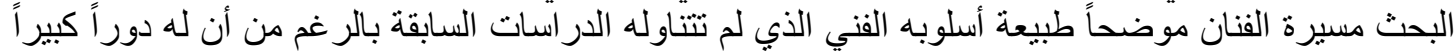

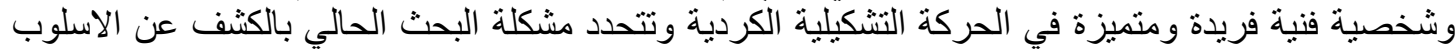

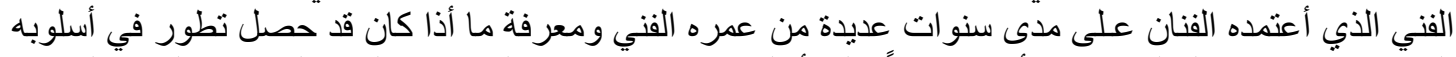

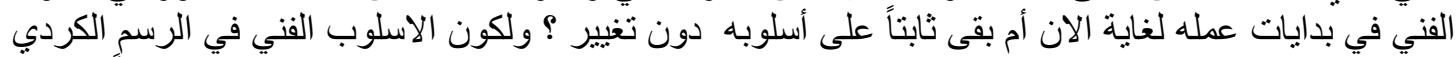

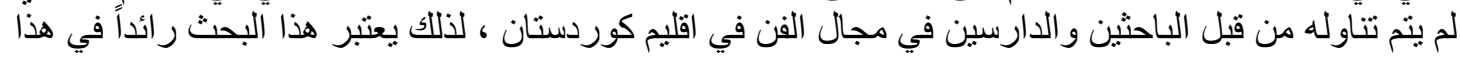

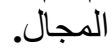

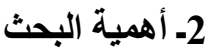
1- نوسيع نشر مفهوم الأسلوب الفني في مجتمعنا قد بيساعد على فهم الناس لطبيعة ( الأسلوب الفني) في الفن التشكيلي الكردي وخاصة في أعمال الفنان خيري آدم. 2- يساهم في رفد الحركة التشكيلية بالمعرفة و في إغناء دراسات تأريخ الفن الكردي ، و كذلك يساهم في عمل توثيقي لأحد جوانب الخبرة الفنية الكوردستانية.

3- يفيد في الدراسات الأكاديمية والعلمية والتوثيق في كل من كلية الفنون ومعهد الفنون الجميلة ومعهد الفنون

1- الحدود الزمانية: يقتصر البحث على اللوحات الزيتية للفنان من عام 2014 الى الى عام 2016.

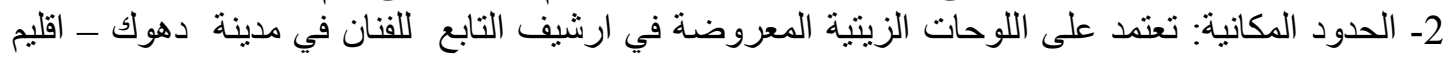




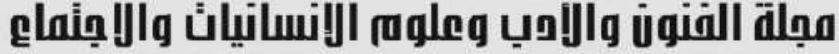

\section{Journal of Arts, Literature, Humanities and Social Sciences} www.jalhss.com

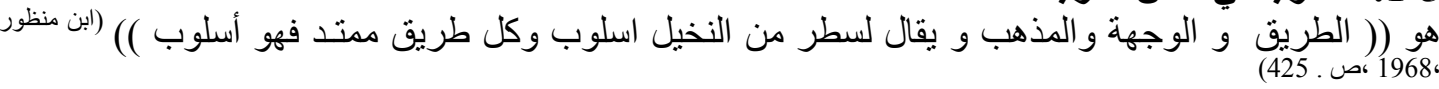

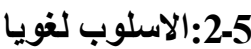

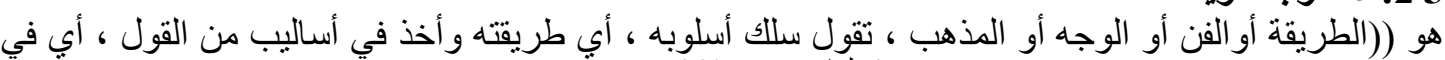

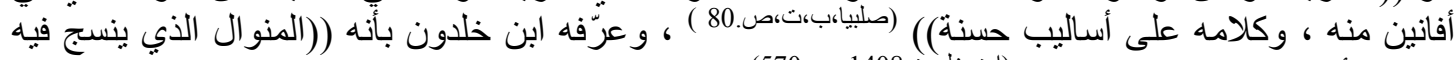

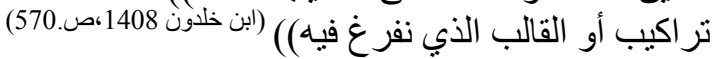
3-5 التعريف الاجرائي للأسلوب:

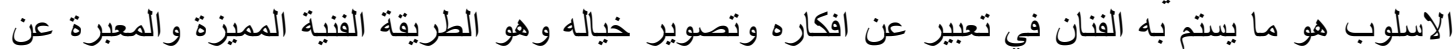

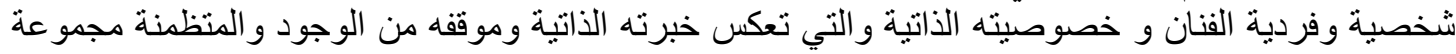

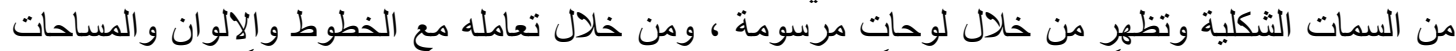

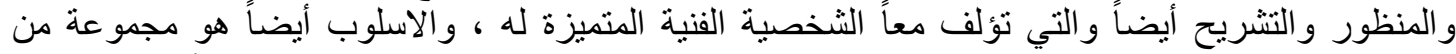

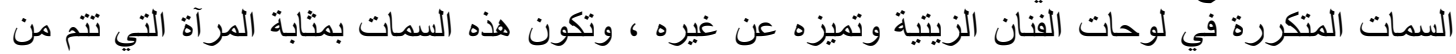

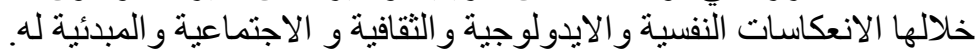

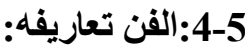

الفن عند ناثان نوبلر هو ((نتاج أنساني تنظم فيه المواد بحذق ومهارة لكي يصل الى تجربة إنسانية))

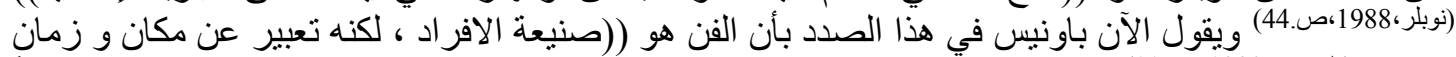

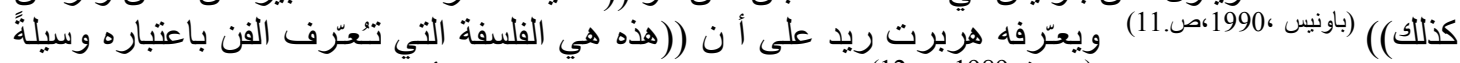

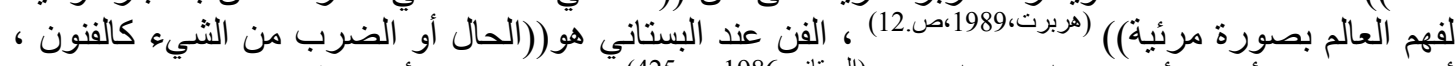

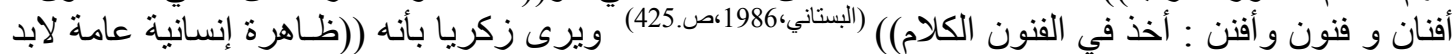

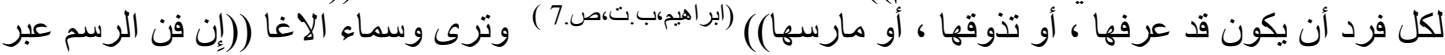

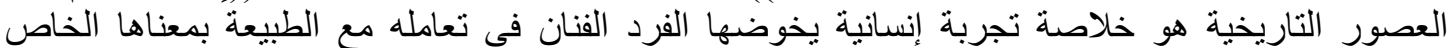

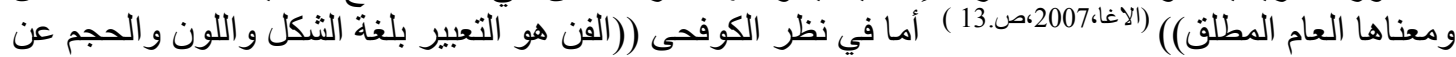

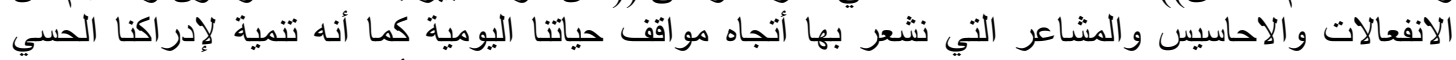

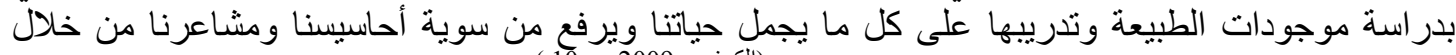

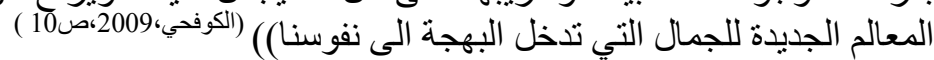
5-5 التعريف الاجرائي للقن:

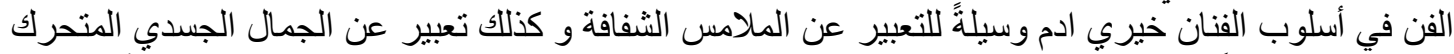

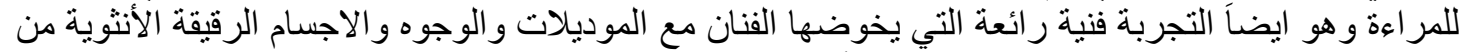

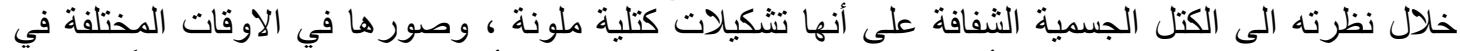

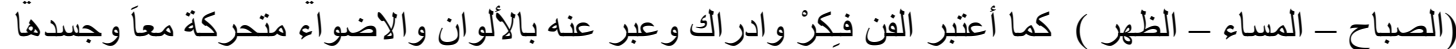
في لوحات مرسو مة بمادة الزيت و بأسلوب منير منميز. 6 6 1-6 : المبحث الاولّ : نبذة عن تأريخ الأسلوب الفني

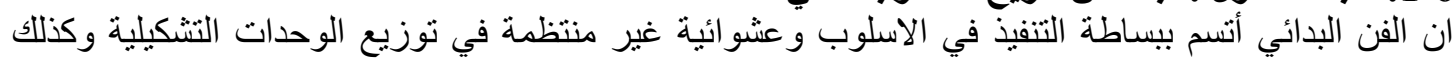

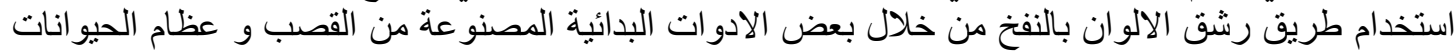

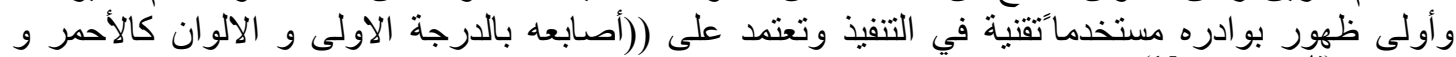

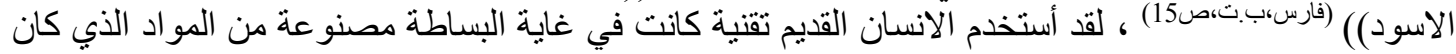

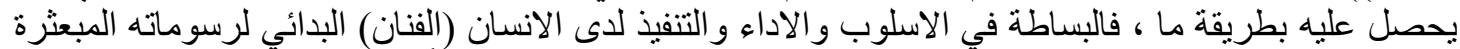

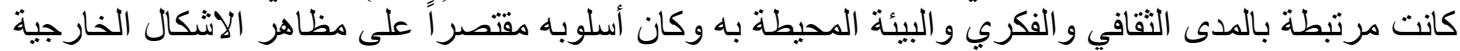

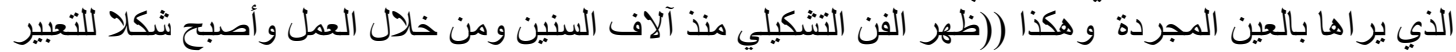

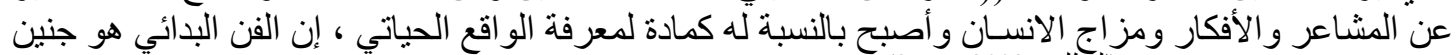

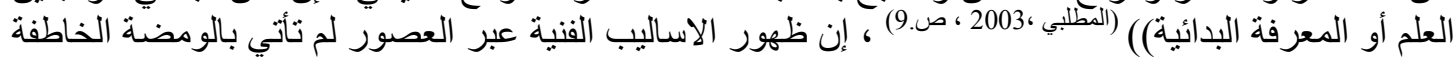




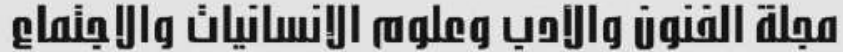 \\ Journal of Arts, Literature, Humanities and Social Sciences www.jalhss.com

إنما اتى عبر الازمان ومراحل المختلفة وبعد تقلبات عدة وتعتبر المظاهر التي أثرت على ظهور الطرق

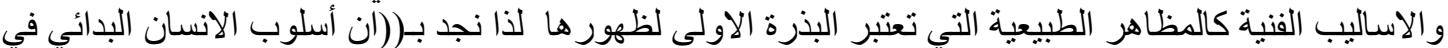

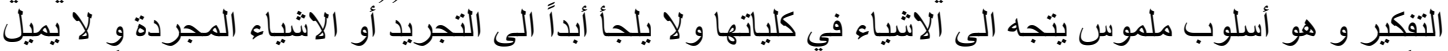

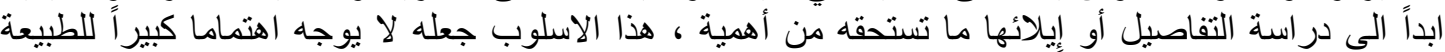

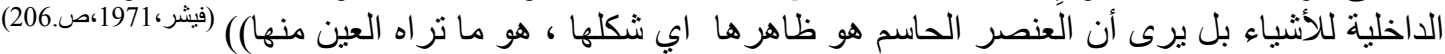

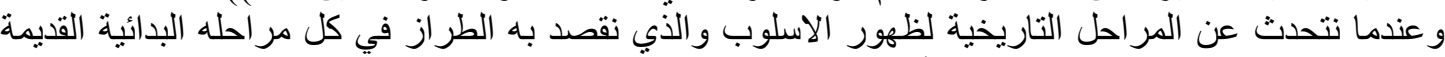

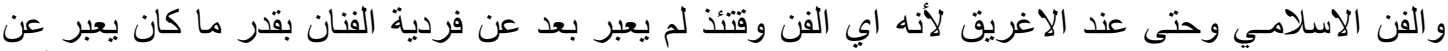
مرحلة حضارية معينة تمتد الى مئات السنين ، ففي بلاد ما بين النهرين (الميزوبوتاميا) والتي تعنبر من أقدم

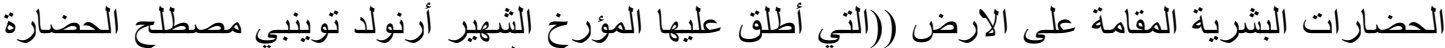

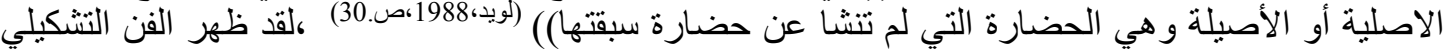

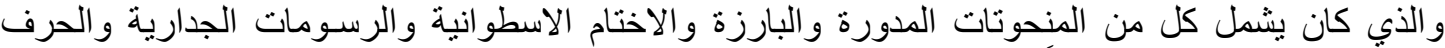

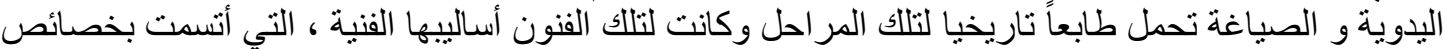

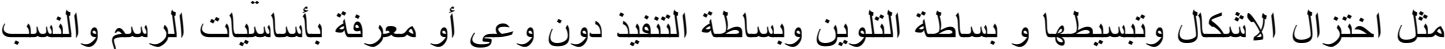

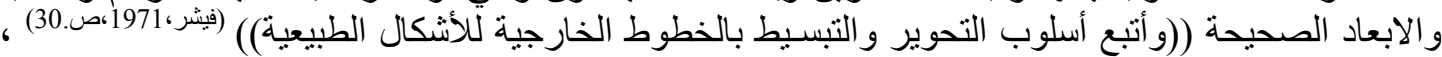

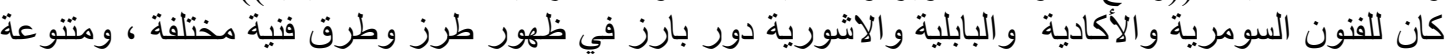

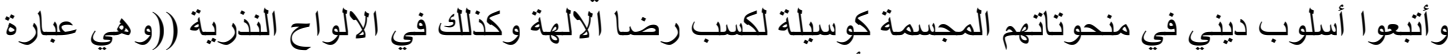

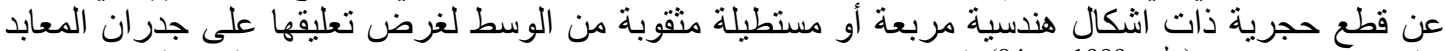

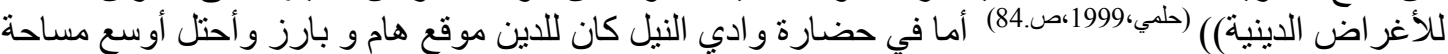

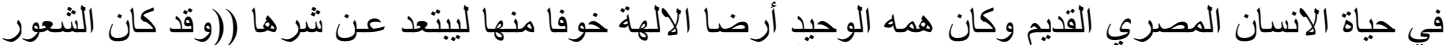

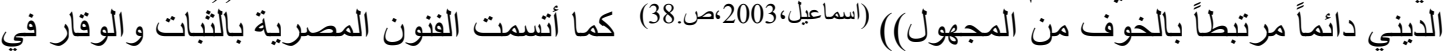

تجسبد صور ومنحونات ملوكهم ، مثل (اخناتون وزوجته) انظر (شكل 1-2-3) وكان لهم أسلوب واحد نسبة

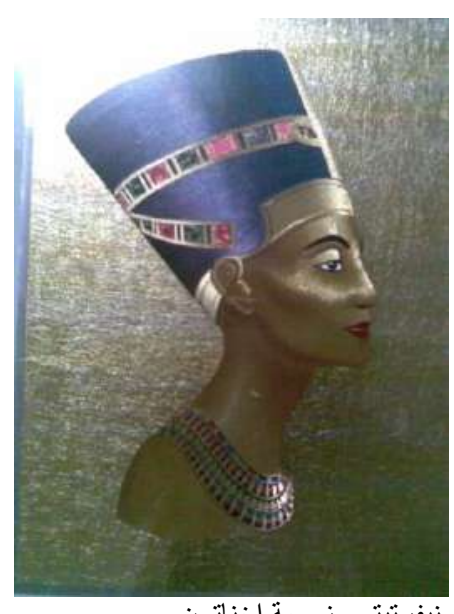

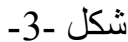

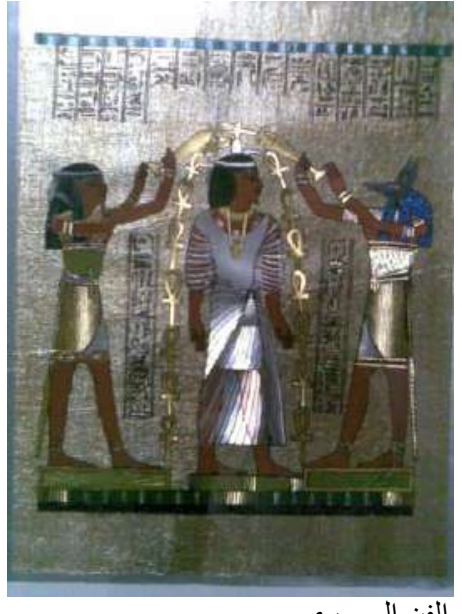

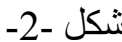

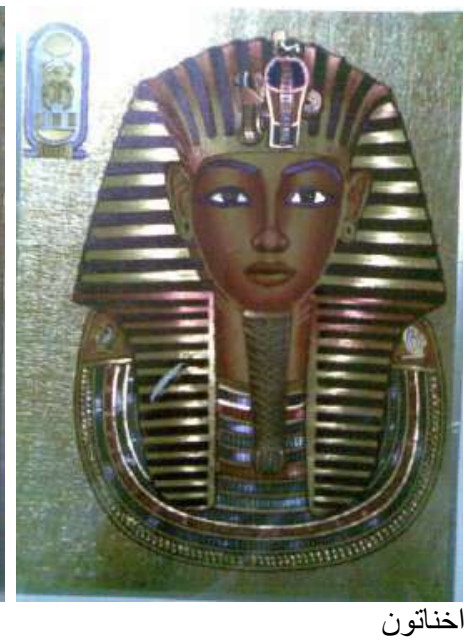

شكل -1-

الى عقيدتهم أي أيمانهم بالحياة الثانية بعد الموت وكان الاسلوب الفني عند الفنان المصري القديم مثير للاهتمام

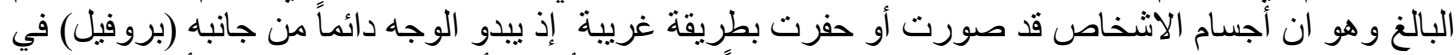

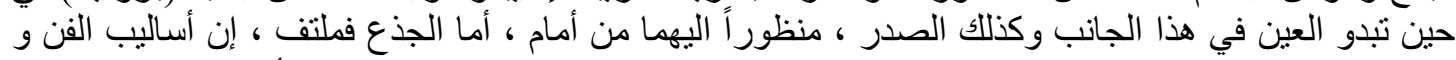

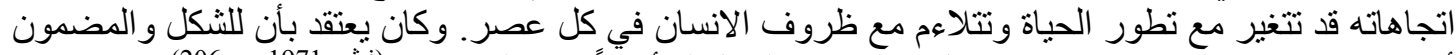

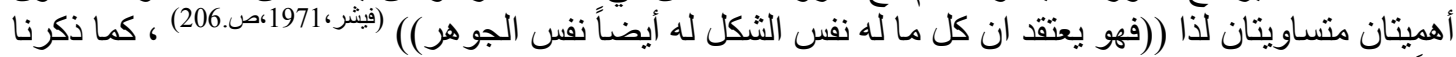

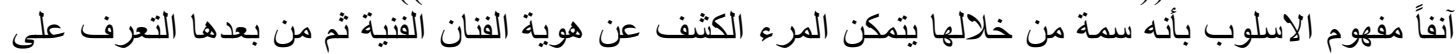
المدرسة الفنية المتبعة وهذا ما يقودنا الى أن هنالك علاقة قوية ومنر ابطة ذات تناسب طردي مني بين كل من الفنان 


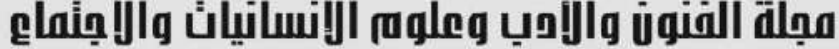 \\ Journal of Arts, Literature, Humanities and Social Sciences www.jalhss.com

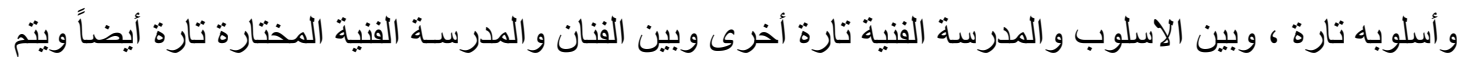

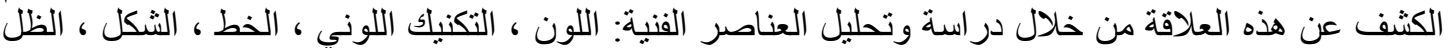

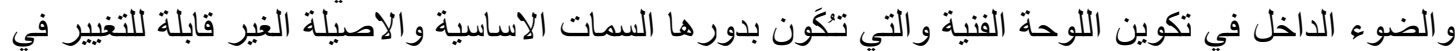

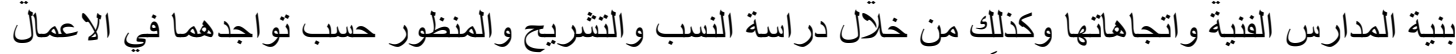

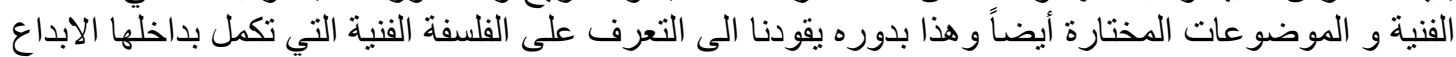

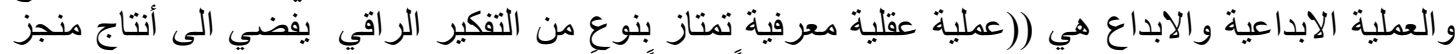

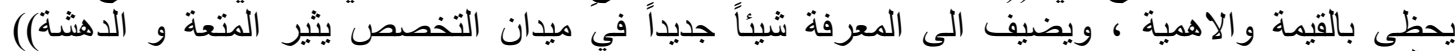

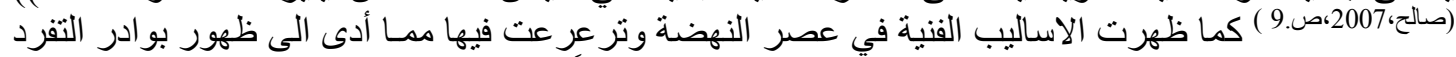

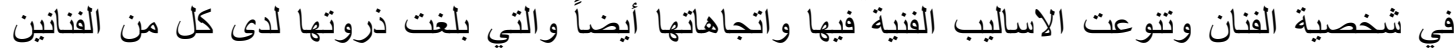

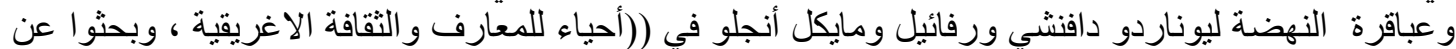

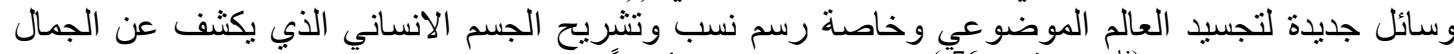

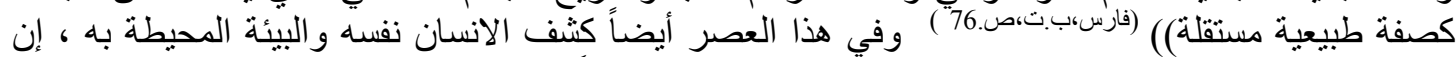

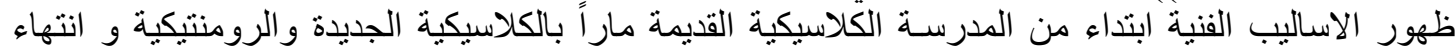

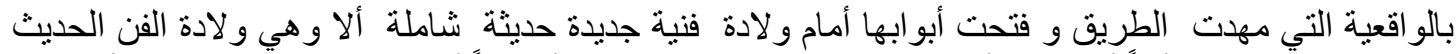

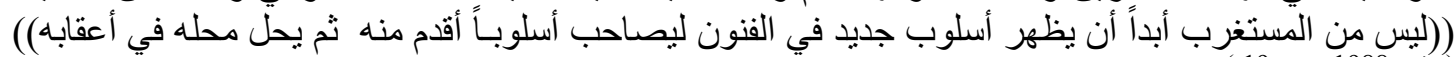

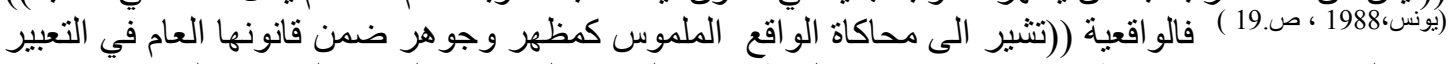

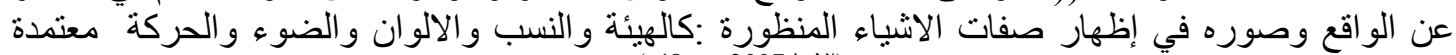

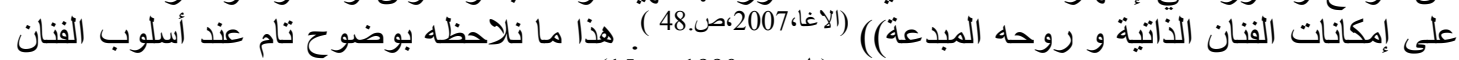

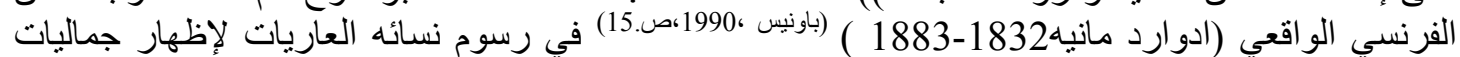

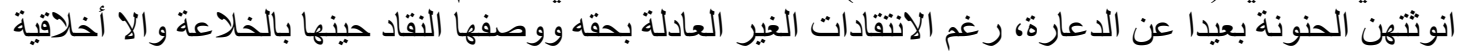

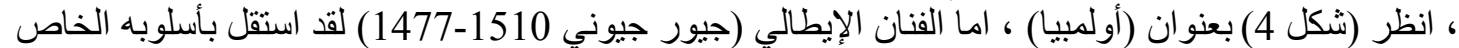

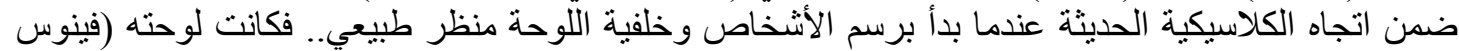

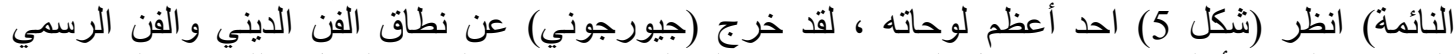

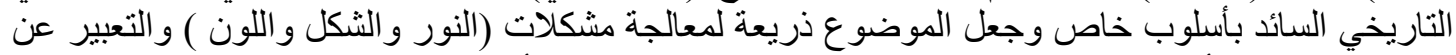

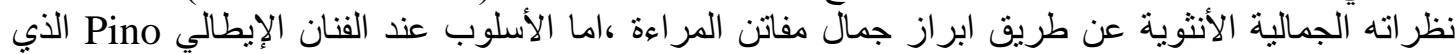

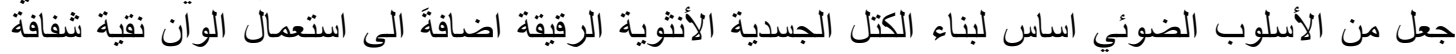

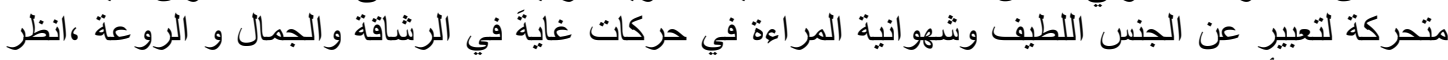

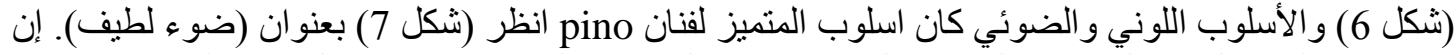

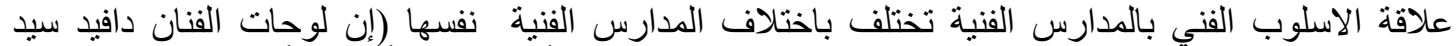

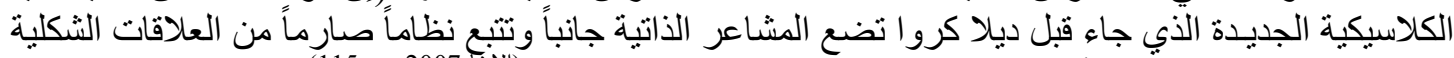

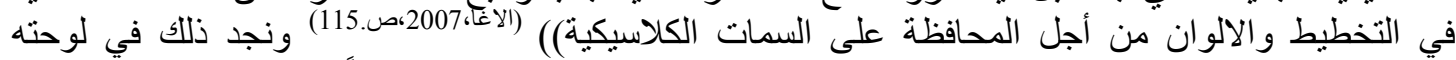

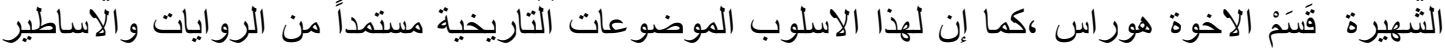

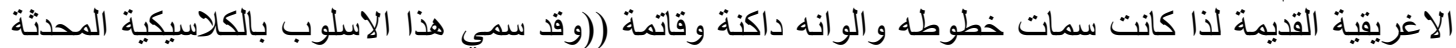

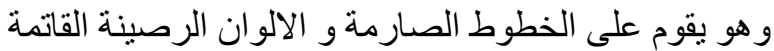




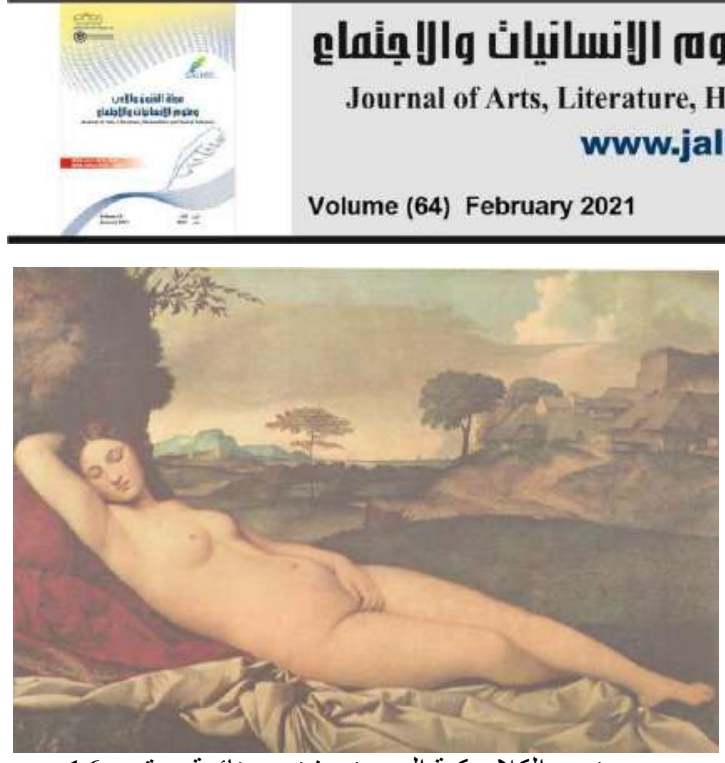

جيور جيوني - الكلاسيكية الجديدة - فينوس نائمة ـ قرن 16

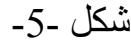

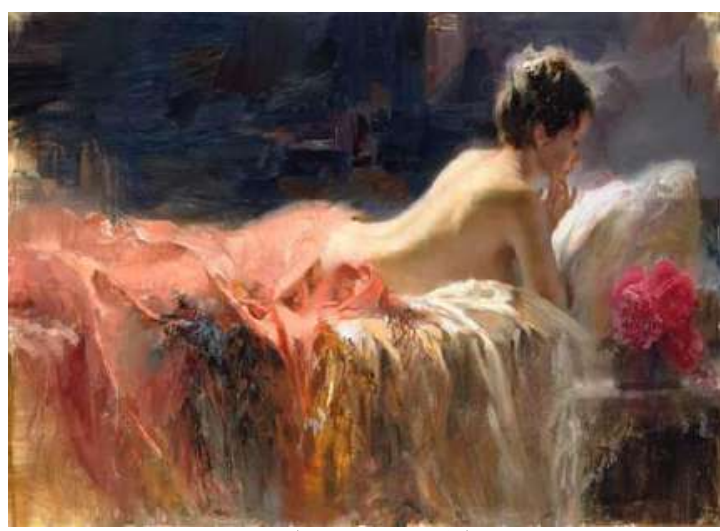

2010 - ضو - pino

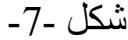

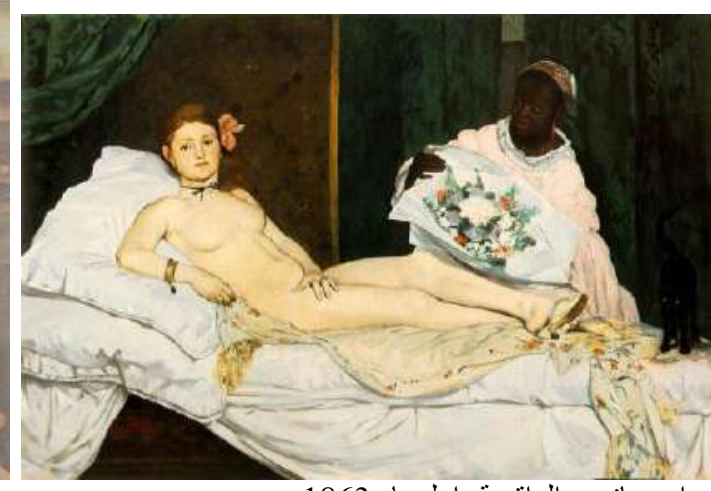

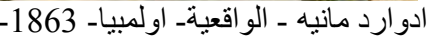

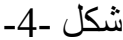

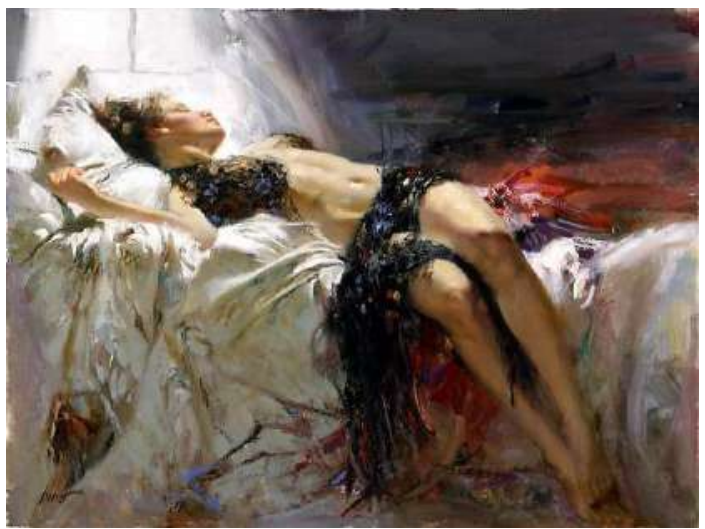

Pino

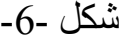

بعيداً عن أهو اء العاطفة)) (الكوفح،2009،ص.216 ) ، أما في المدرسة الرومنتيكية بدأت السمات الفنية تطرأ عليها

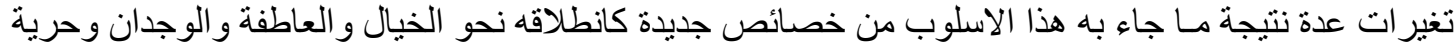

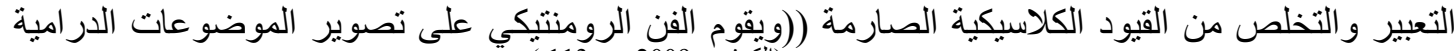

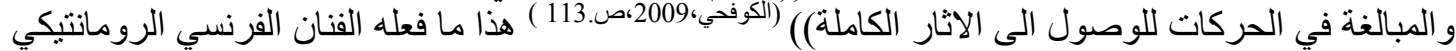

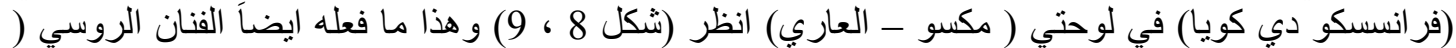
(Serge Marshennikor

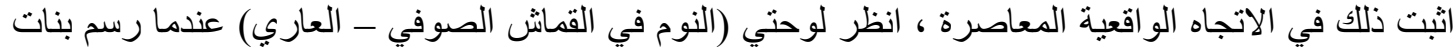

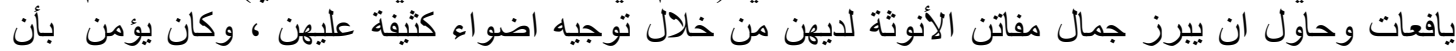

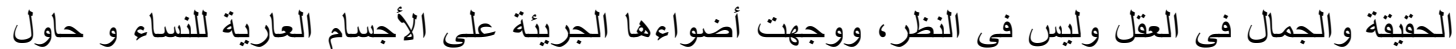

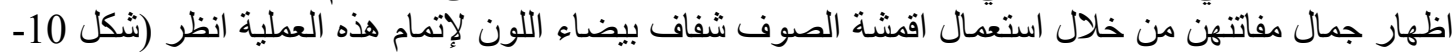

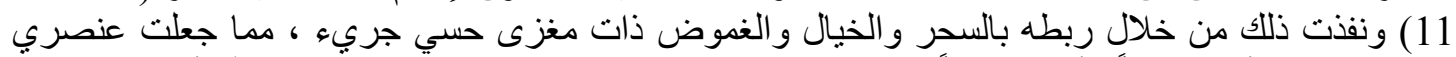

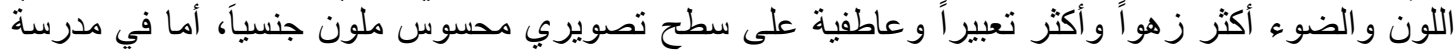

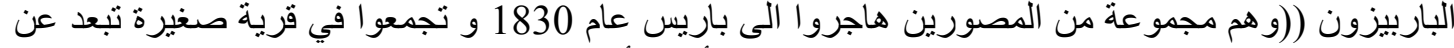

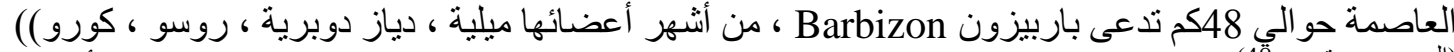

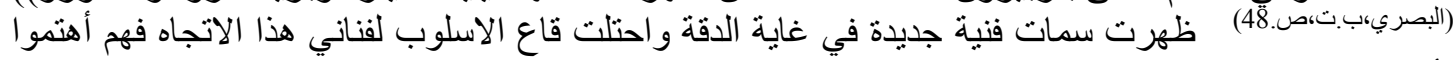

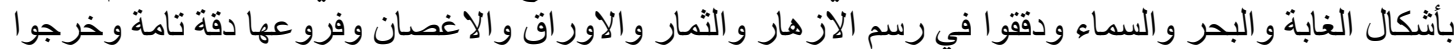

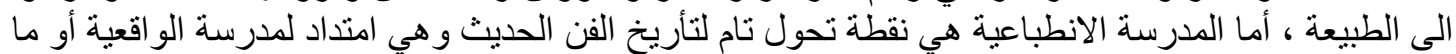

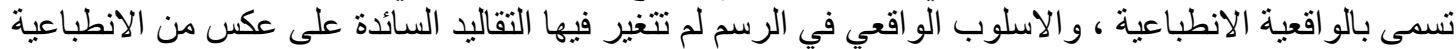

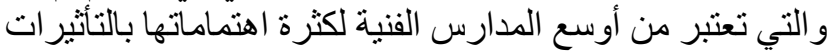




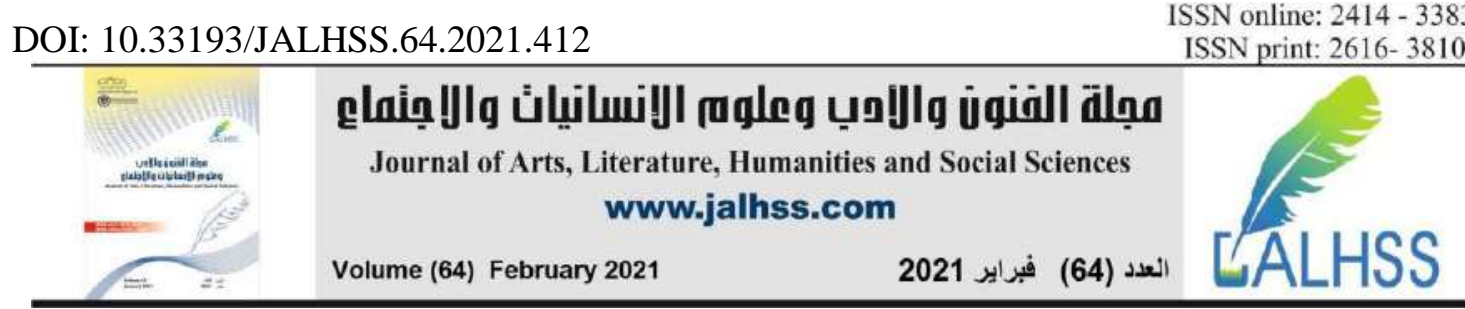

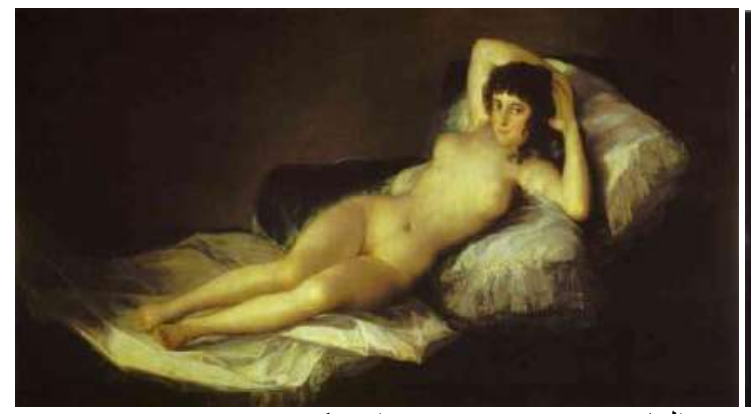

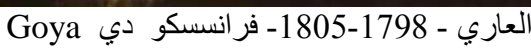
شكل -9-

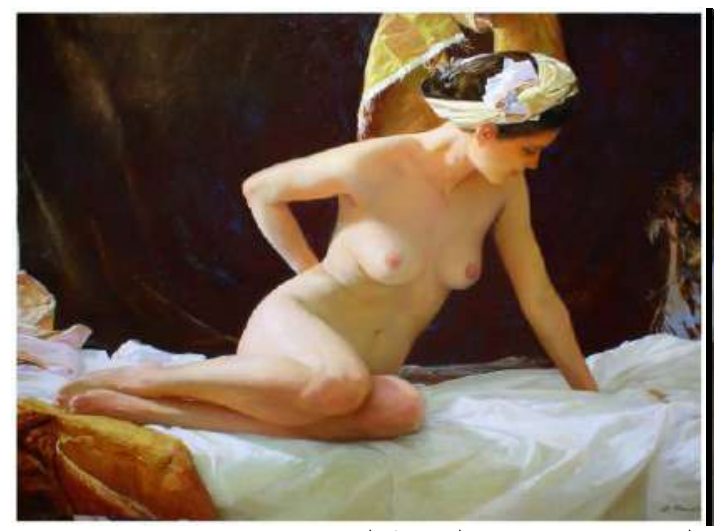

العاري - Serge - الو اقعية المعاصرة - 2012 شكل - 11-

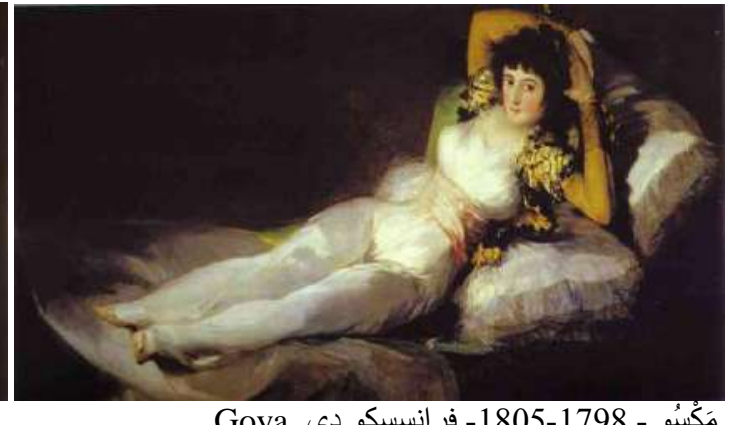

Goya مَكُسُو - 1805-1798- فر انسسكو دي -8 شكل -8- فيكر

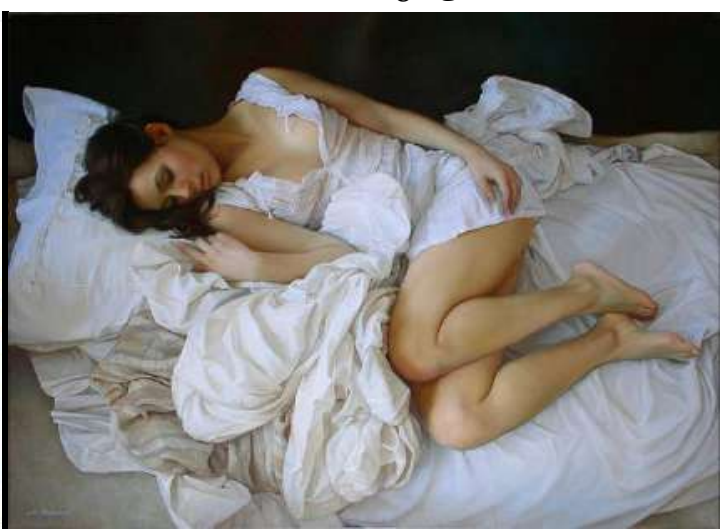

النوم - Serge - الواقعية المعاصرة - 2012 شكل -10-

الضوئية والتغييرات التي تطر أ على الشكال والاجسام الموجودة في الطبيعة بسبب تغير حركة الثمس

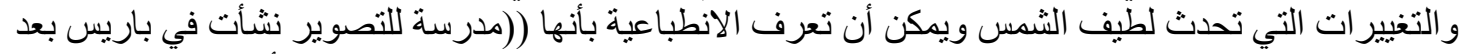

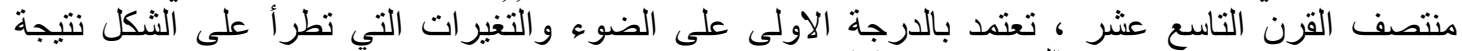

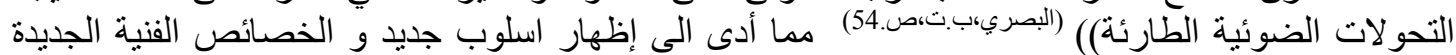
باستخدام اللون مباشرة من الباليت الى سطح اللوحة دون مزجه بلون آخر و إعطاء الالوان شفافية أكثر و إعطاء

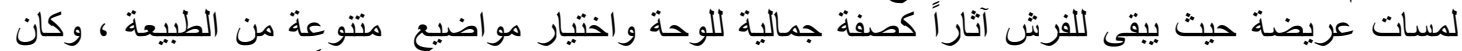

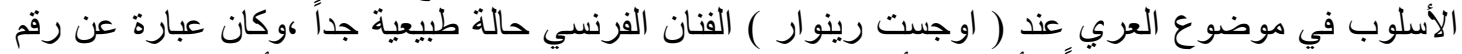

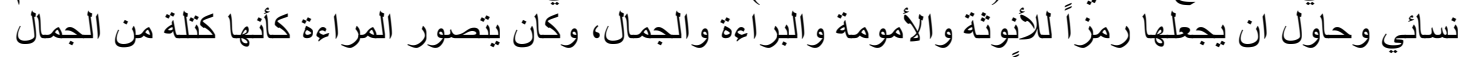

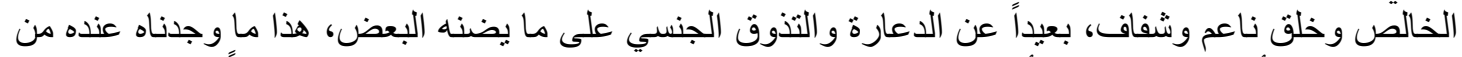

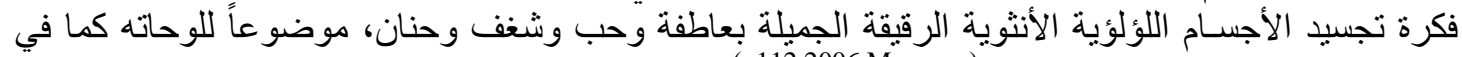

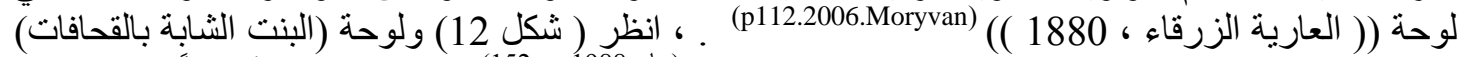

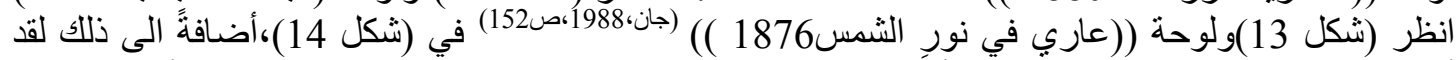

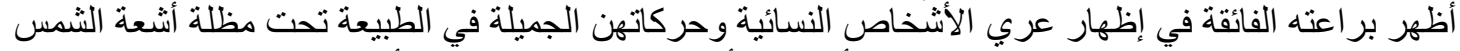

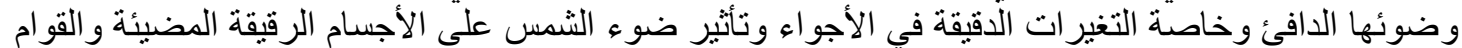

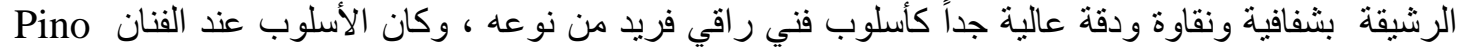

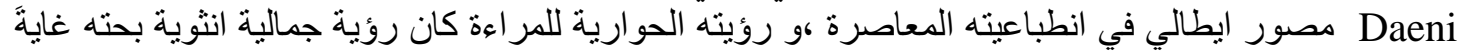

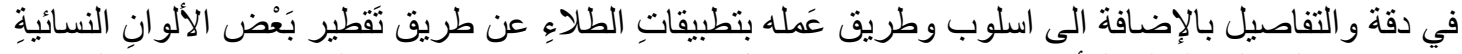

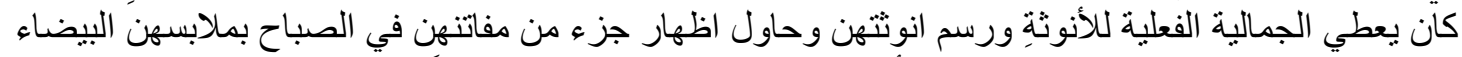

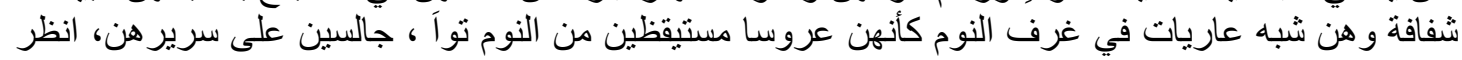

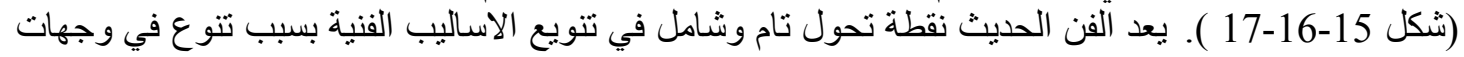




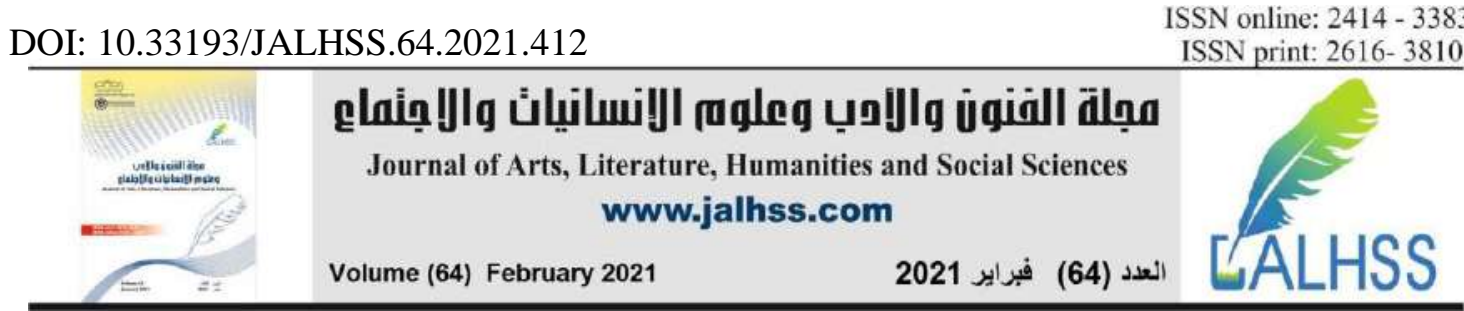

النظر المختلفة وكذلك ظهور مجموعة من المدارس الفنية في آن واحد ،أما أذا أخذنا بنظر الاعتبار الاسلوب

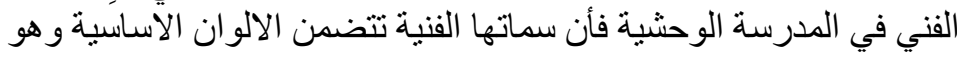

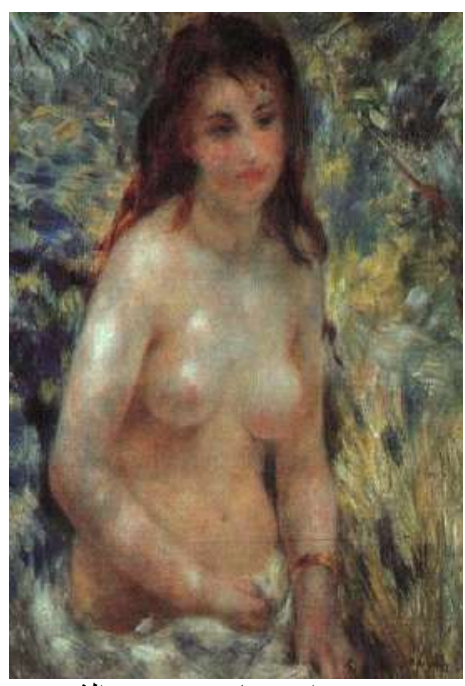

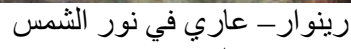

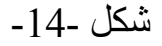

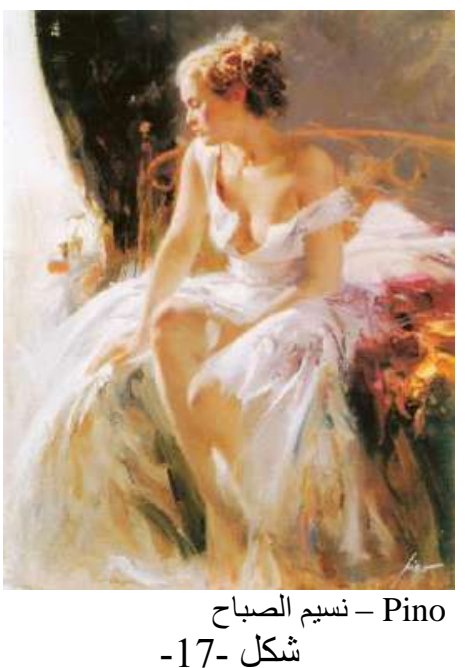

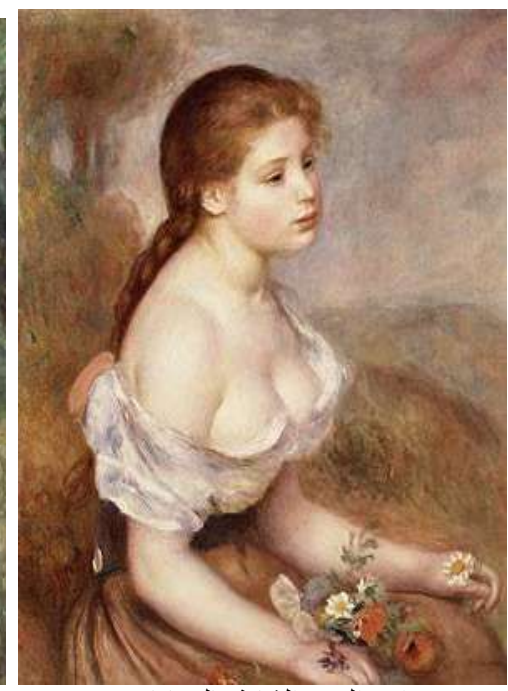

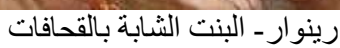

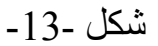

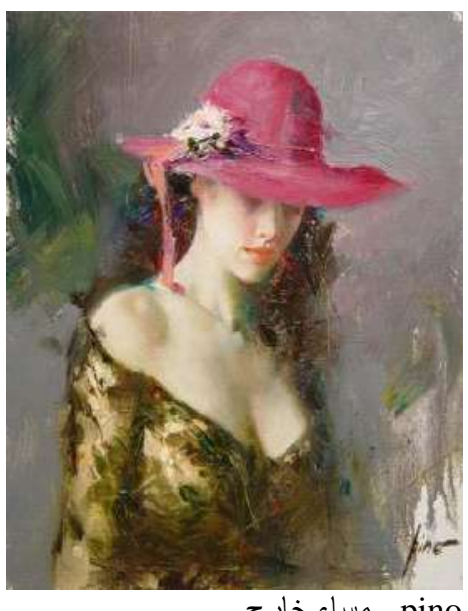

- مساء خارج - pino

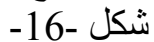

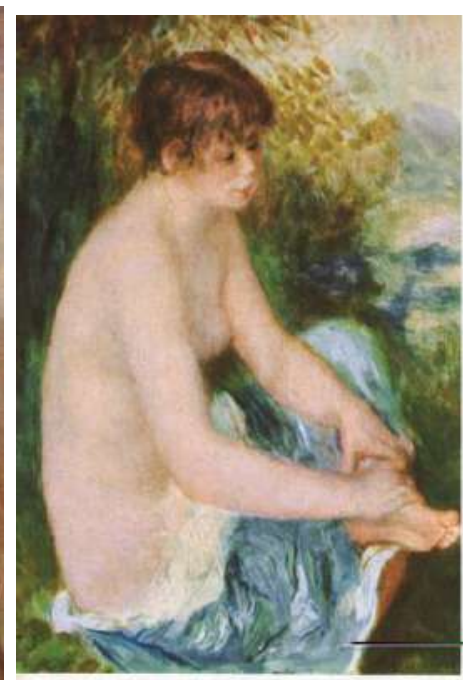

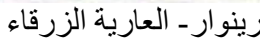

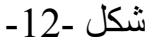

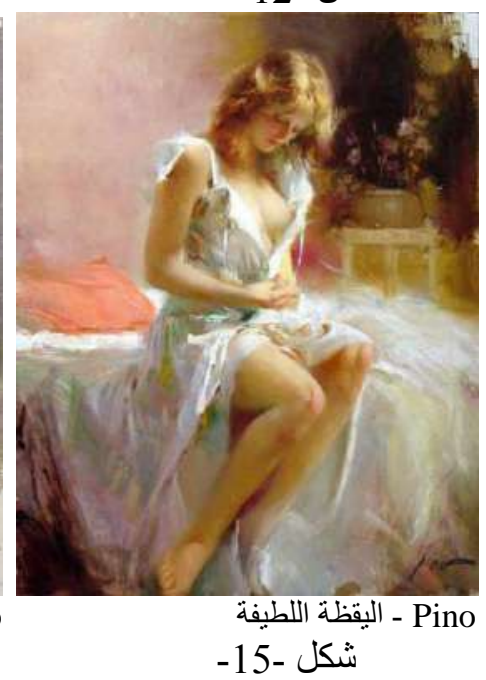

الثلاث الازرق ، الاحمـر ، الاصفر ومن هنا نجد بأن اللون هو سيد الموقف لغة وتعبير وشكل في آنِ آنِ واحد،

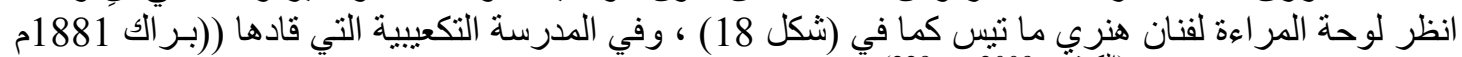

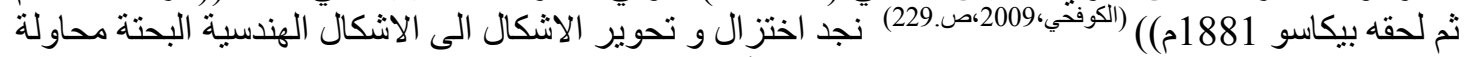

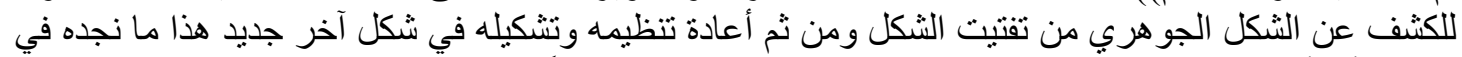

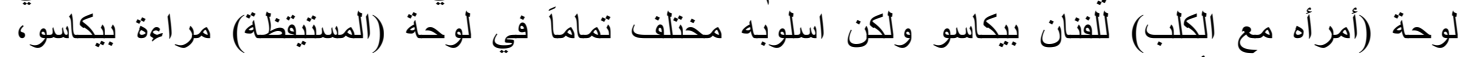

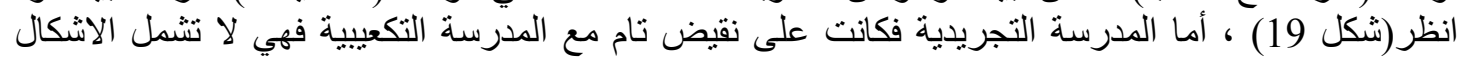

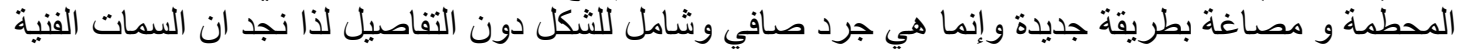

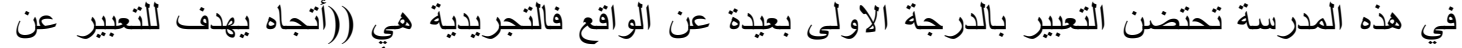

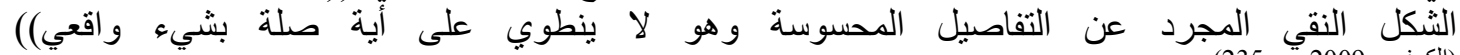
(الكوفي،2009،ص.235) المبالغة في إظهار القيم الجمالية عن طريق رؤيةٍ مختلفة وهذا ما نحسه في المدرسة 


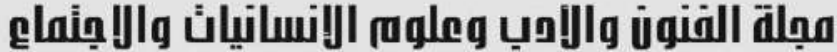 \\ Journal of Arts, Literature, Humanities and Social Sciences www.jalhss.com

التجريدية التي ((تخطت الو اقع الموضوعي بإظهار قيم جمالية مبالغ فيها اعتمدت رؤية بصرية متنوعة ومتعددة

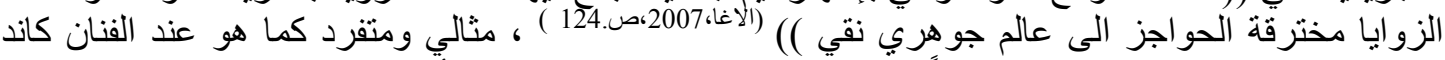

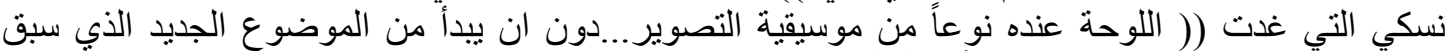

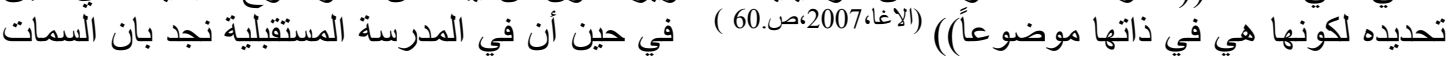

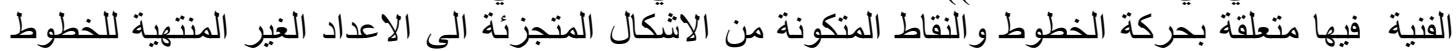

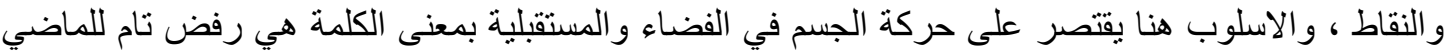

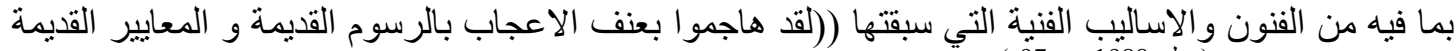

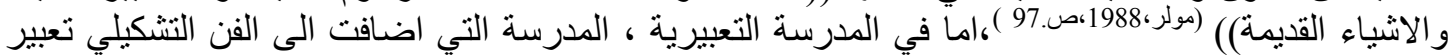

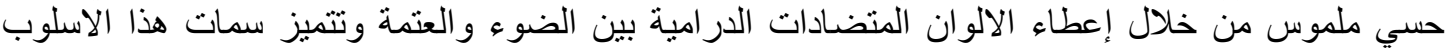

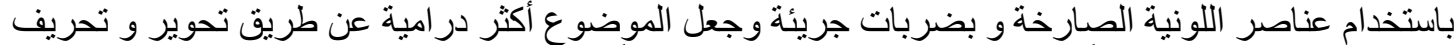
الاشكال كي يكون معبراً ((لذلك كانت التعبيرية تصويراً حياً للانفعالات الباطنية وتدفة دونق العاطفة))

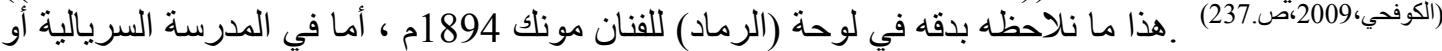

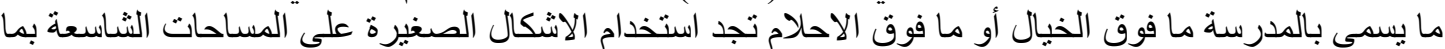

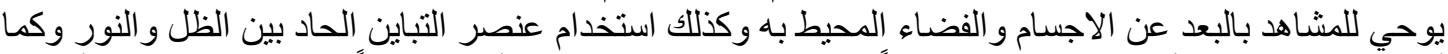
أعطوا للخط حرية أكثر في الحركة ذهاباً و إيابا كي يكون الخط أكثر معبراً فتلك الخصائص الخص أعطت السريالية عمقاً غير

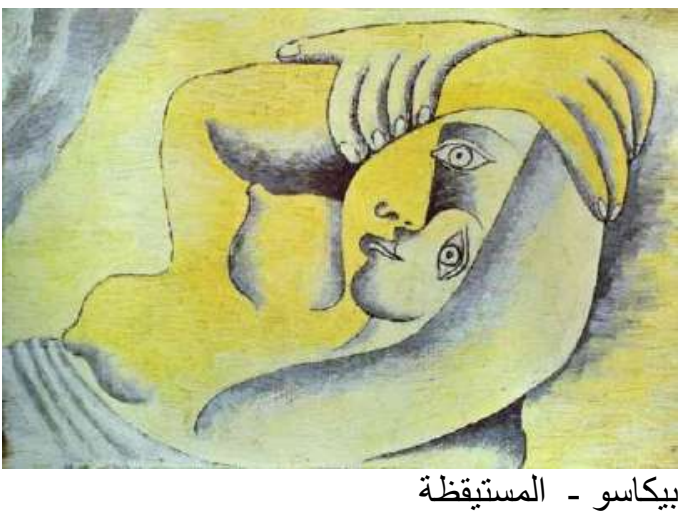

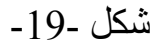

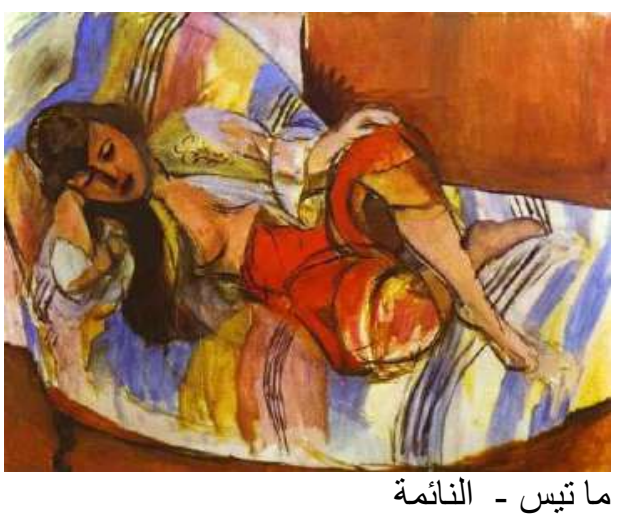

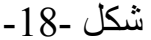

متتاهية وتعد صورة (الحرب الاهلية لفنان سلفادور دالي من المدرسة السريالية من الاعمال التي تثير الصدمة

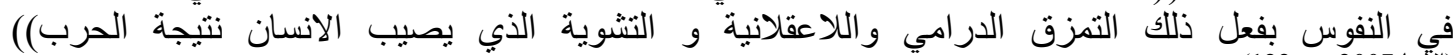

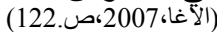

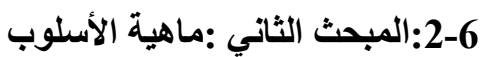

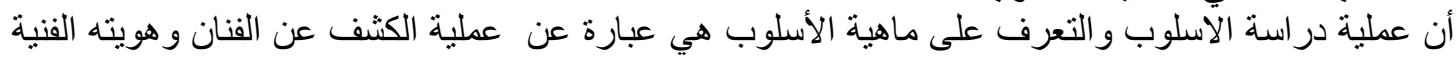

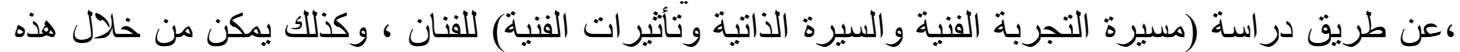

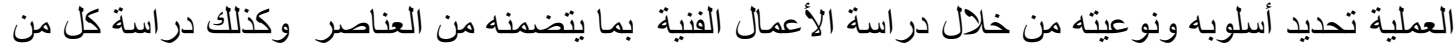

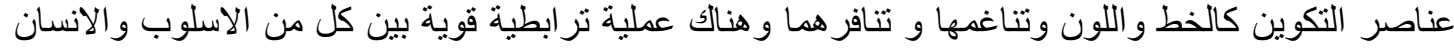

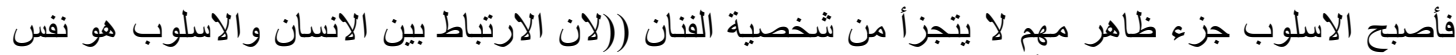

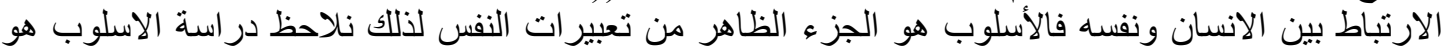

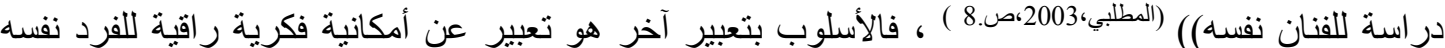

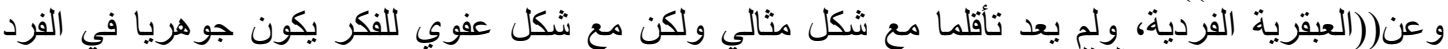

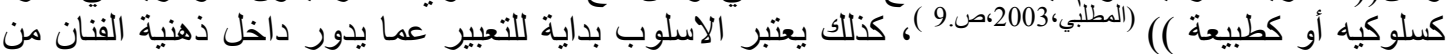

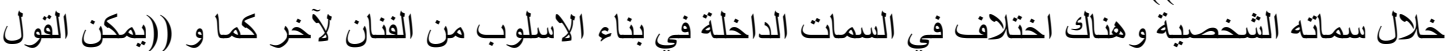

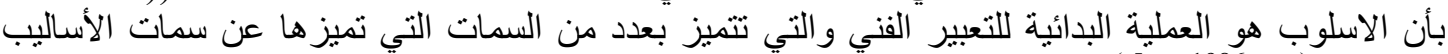

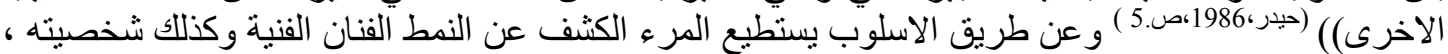




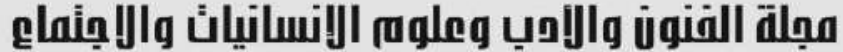 \\ Journal of Arts, Literature, Humanities and Social Sciences www.jalhss.com

أن الانسان والاسلوب وجهان لعملة واحدة ، ان الانسان هو الاسلوب والاسلوب هو تعبير عن شخصية الفنان

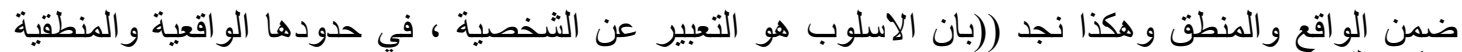

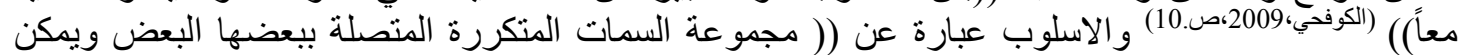

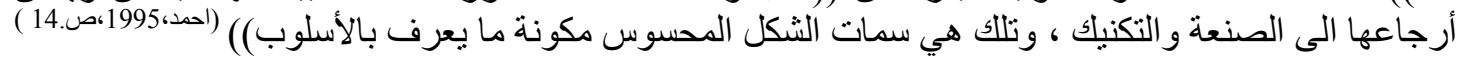

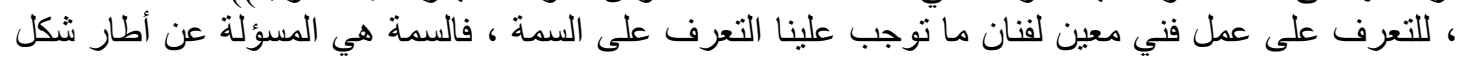

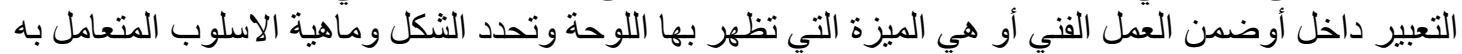

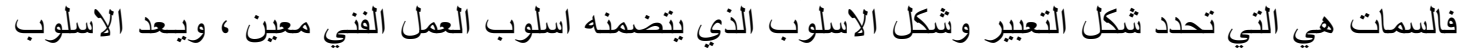

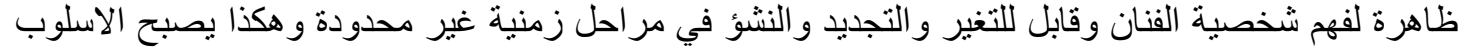

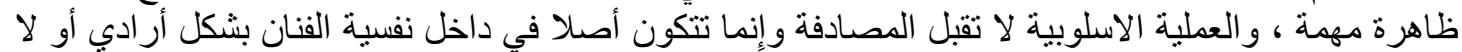

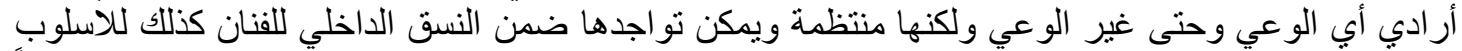

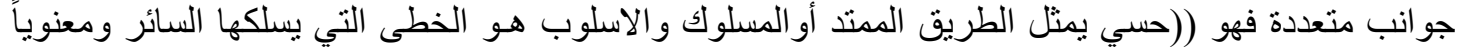

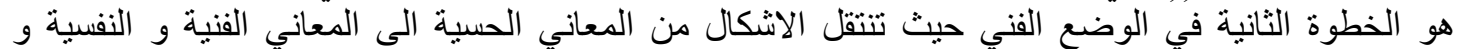

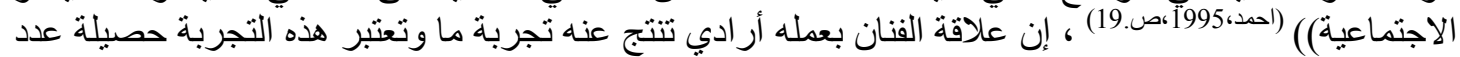

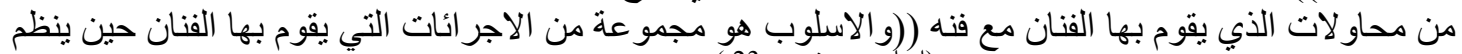

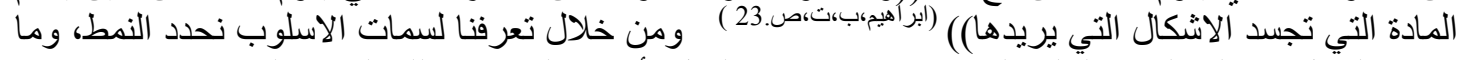

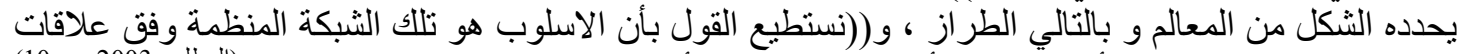

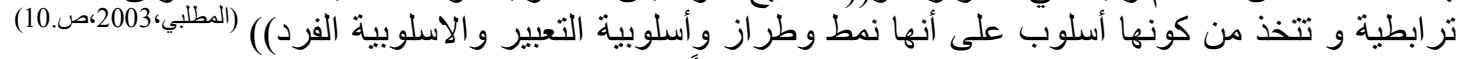

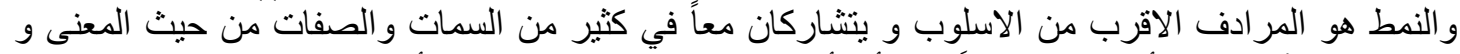

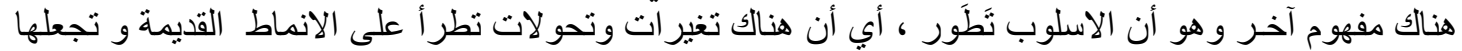

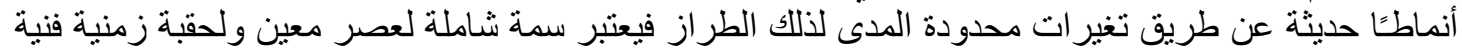

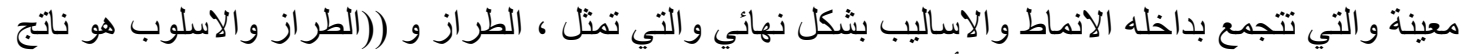

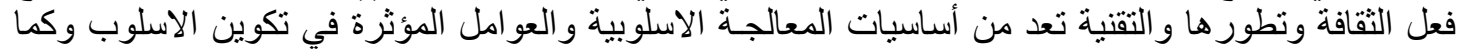

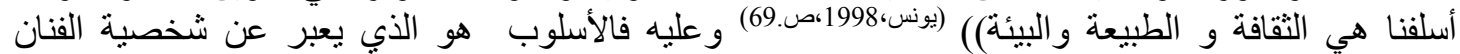

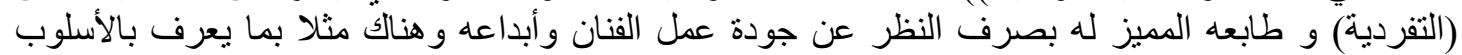

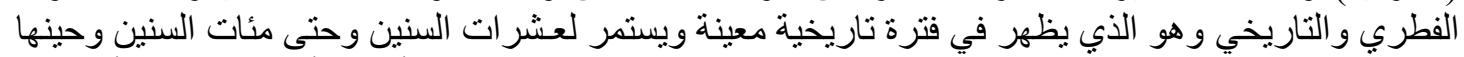

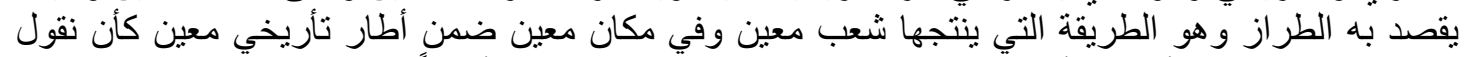

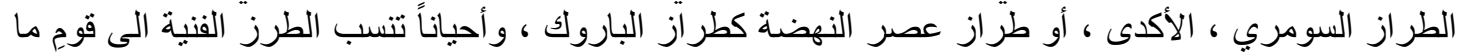

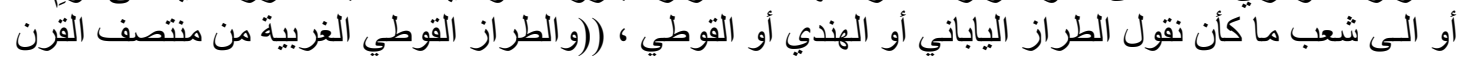

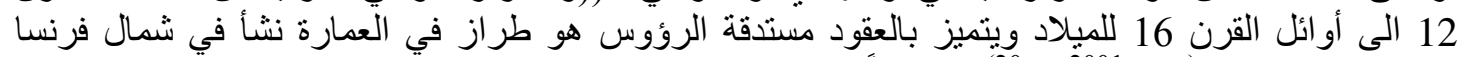

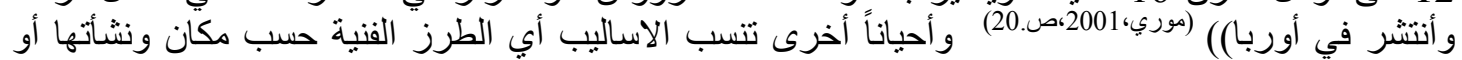

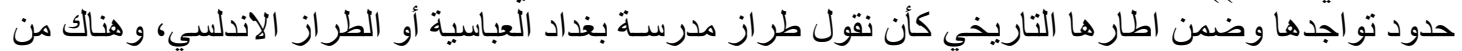

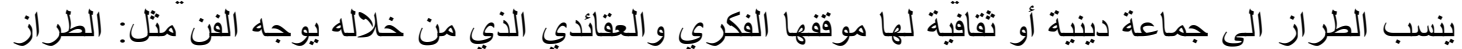

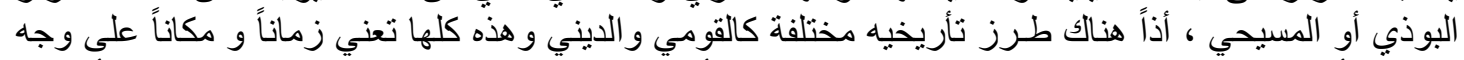

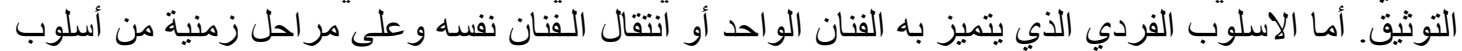

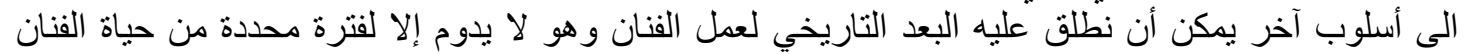

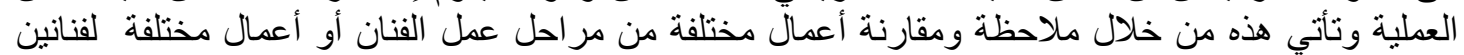

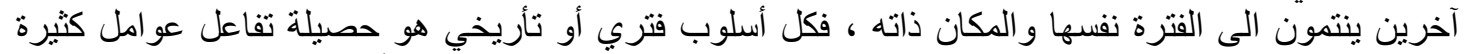

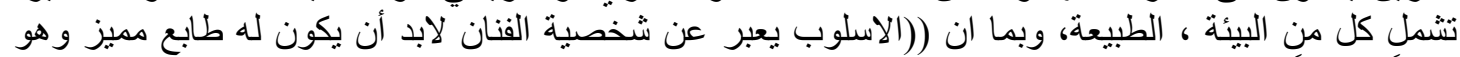

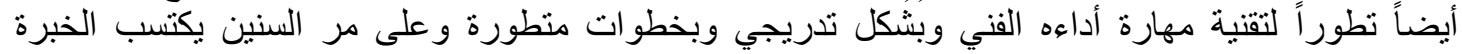

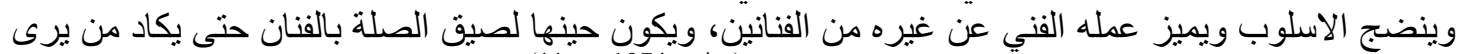

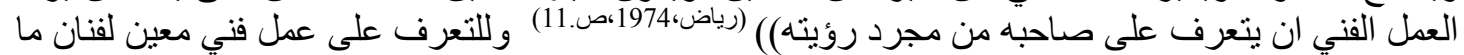

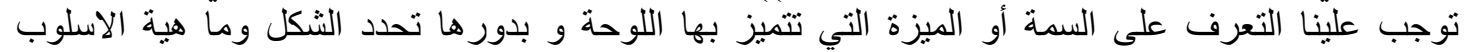

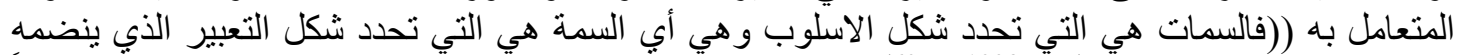

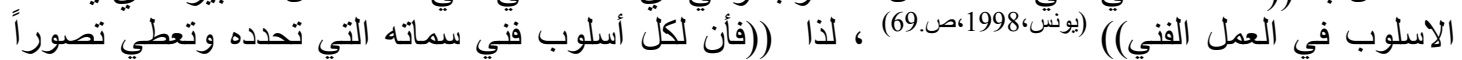




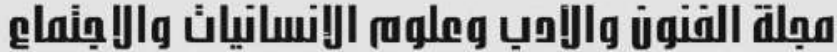 \\ Journal of Arts, Literature, Humanities and Social Sciences www.jalhss.com

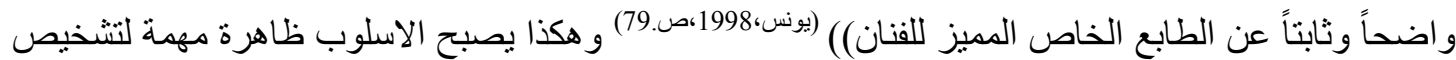

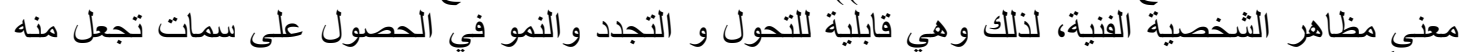

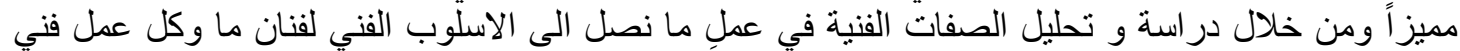

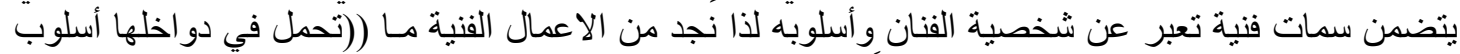

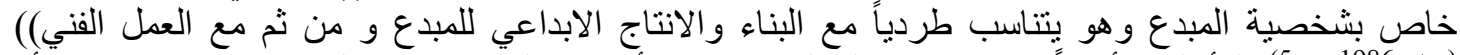

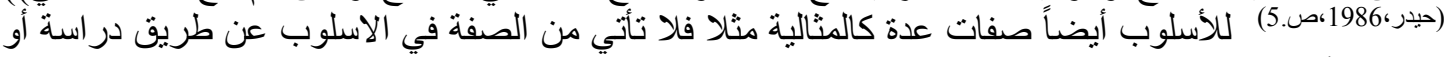

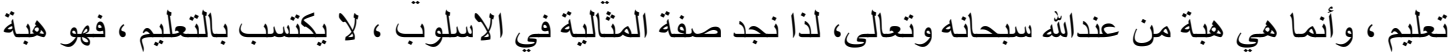

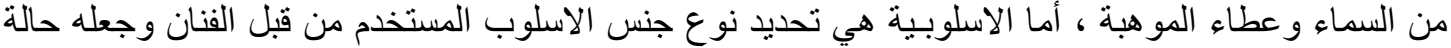

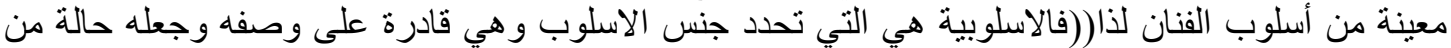

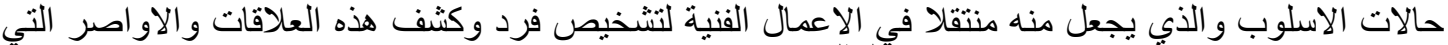

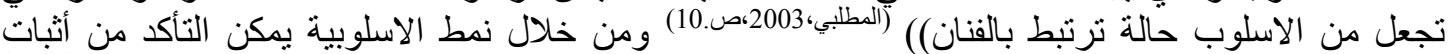

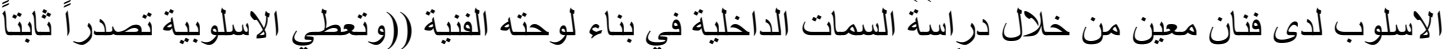

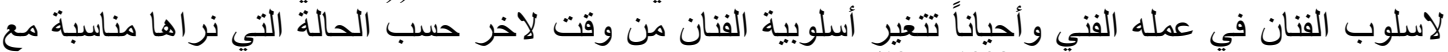

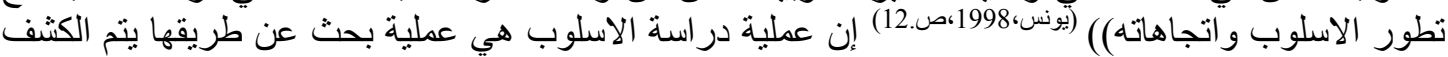

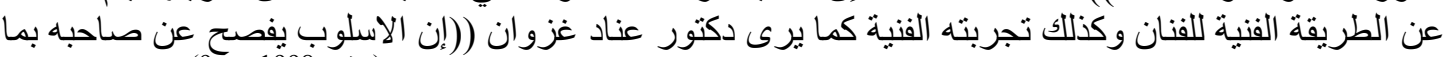

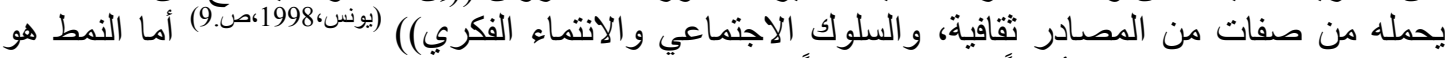

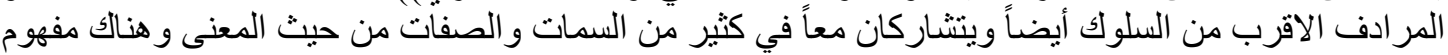

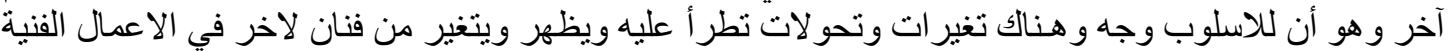

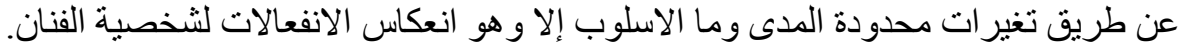
7:النتائج التي أسفر عنها الاطار النظري

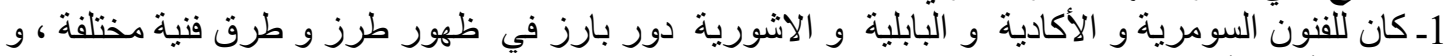

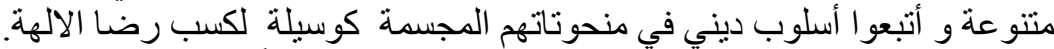

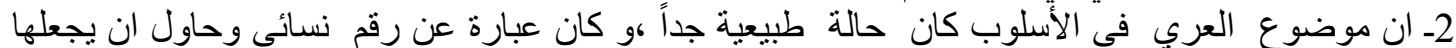

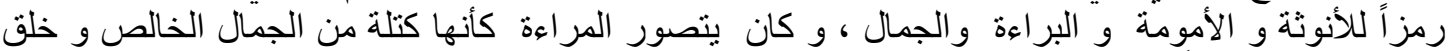

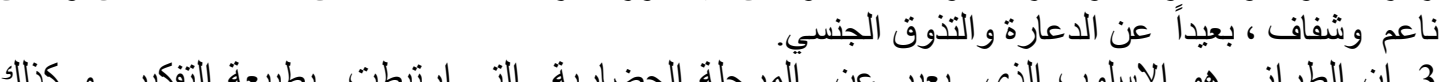

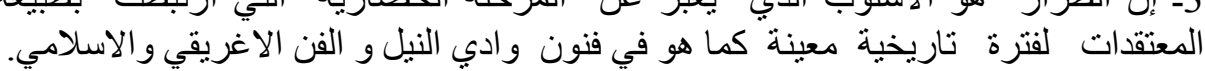

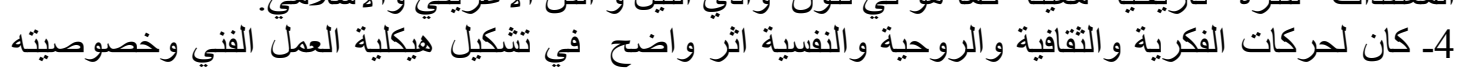

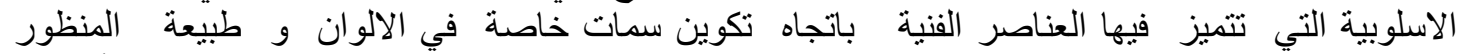

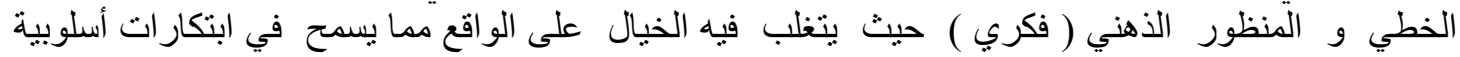
متتوعة كما في المدرسة الزرومانسية والسوري السيالية.

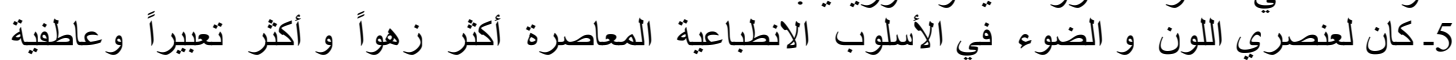

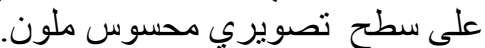

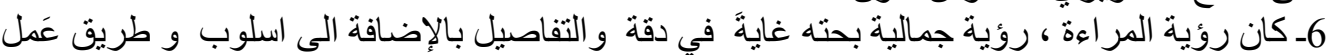

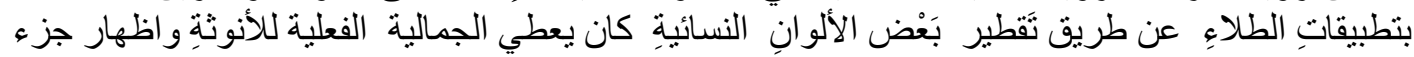

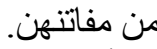
7ـ أهم السمات المعبرة عن الاسلوب المتميز للفنان المبدع هي التفرد والتي ظهرت بشكل ساطع منذ عصر

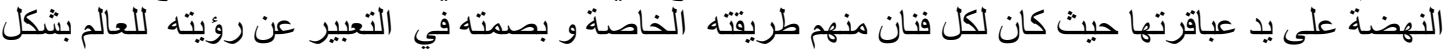

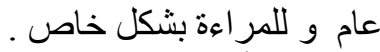

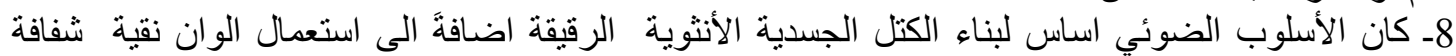

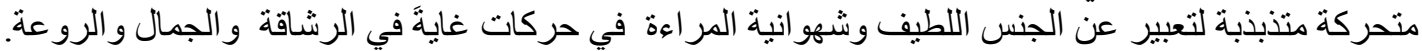

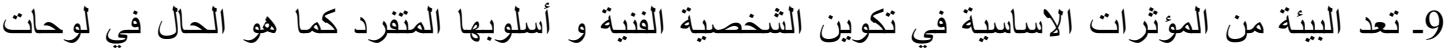

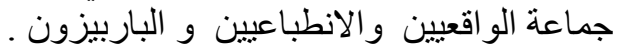




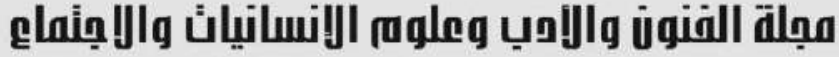

\author{
Journal of Arts, Literature, Humanities and Social Sciences
} www.jalhss.com

10ـ تعتبر المهارة التقنية ( الصناعة ) من العو امل المهمة في التكوين شخصية الفردية للفنان من خلال تعامله

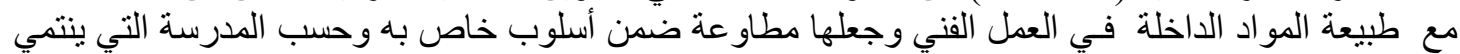
اليها.

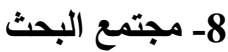

يتكون المجتمع الاصلي من عدد معين من الاعمال الفنية (الرسم) و التي أنجز ها الفنان بمادة الزيت على جنفاص

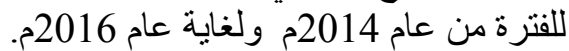

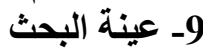

تم اختبار العينات بصور قصدية ضمن الحدود الزمانية و المكانية الدذكورة في البحث وقد تم فرز ها استنادا

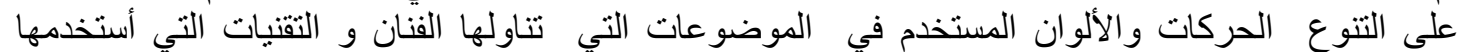

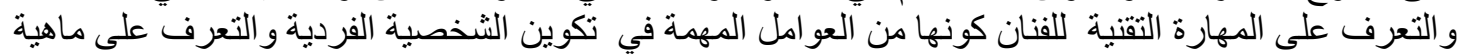
طبيعة الملامس و الخطوط و و الالوان و المساحات و المنظور و التشريح و المناطق الغامقة و الفاتحة والتدرجات

أعتمد الباحث على البحث المنهج التحليلي للاعمال الفنية لتحقيق أهداف البحث.

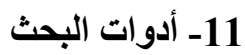

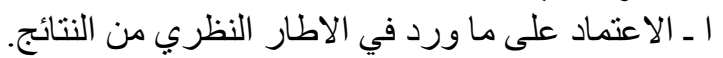
ب ـ ـ الاعتماد على المصادر المكتيبة و الونائق المادئ المادية (اللوحات). ج ـ الاعتماد على المقابلة الشخصية للفنان.

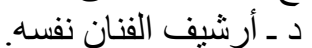

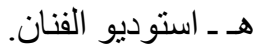

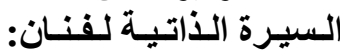

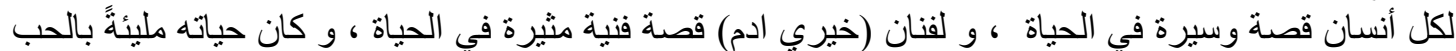

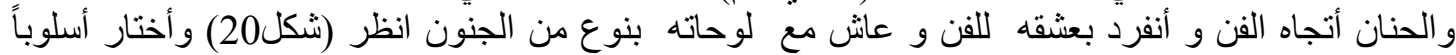

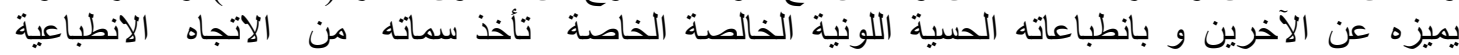

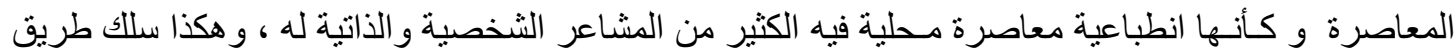

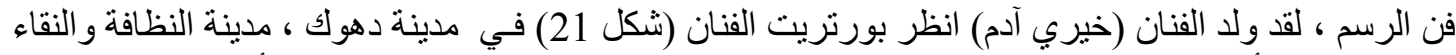

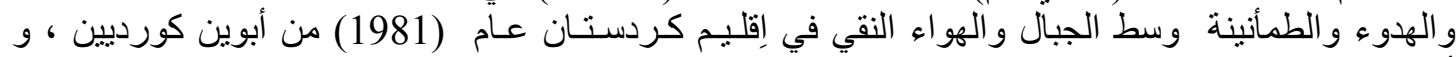

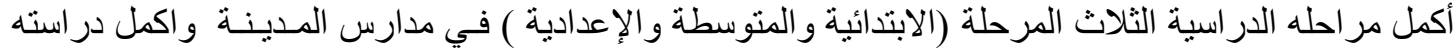

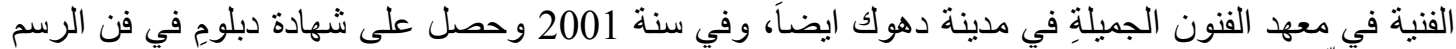

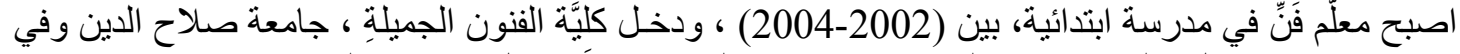

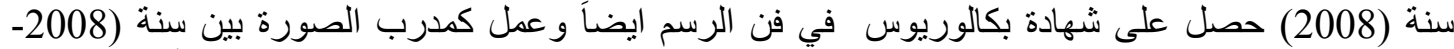

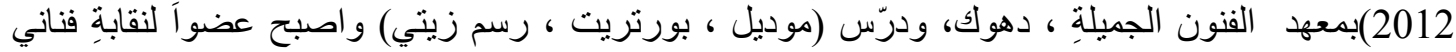

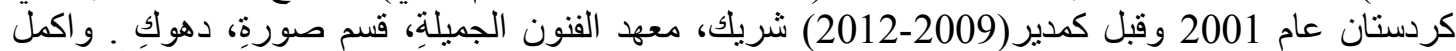

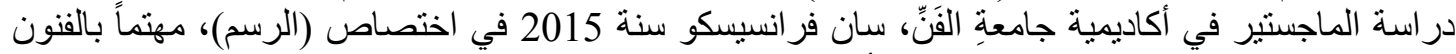

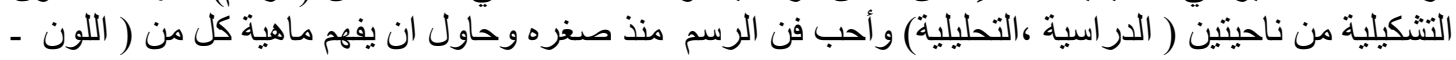
الثكل ـ الضوء ) بكل ما فيهم من الصفات و الخصائص و والسمات.

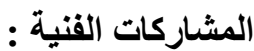

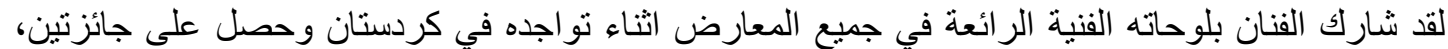

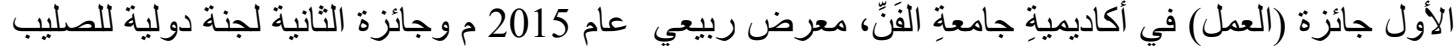



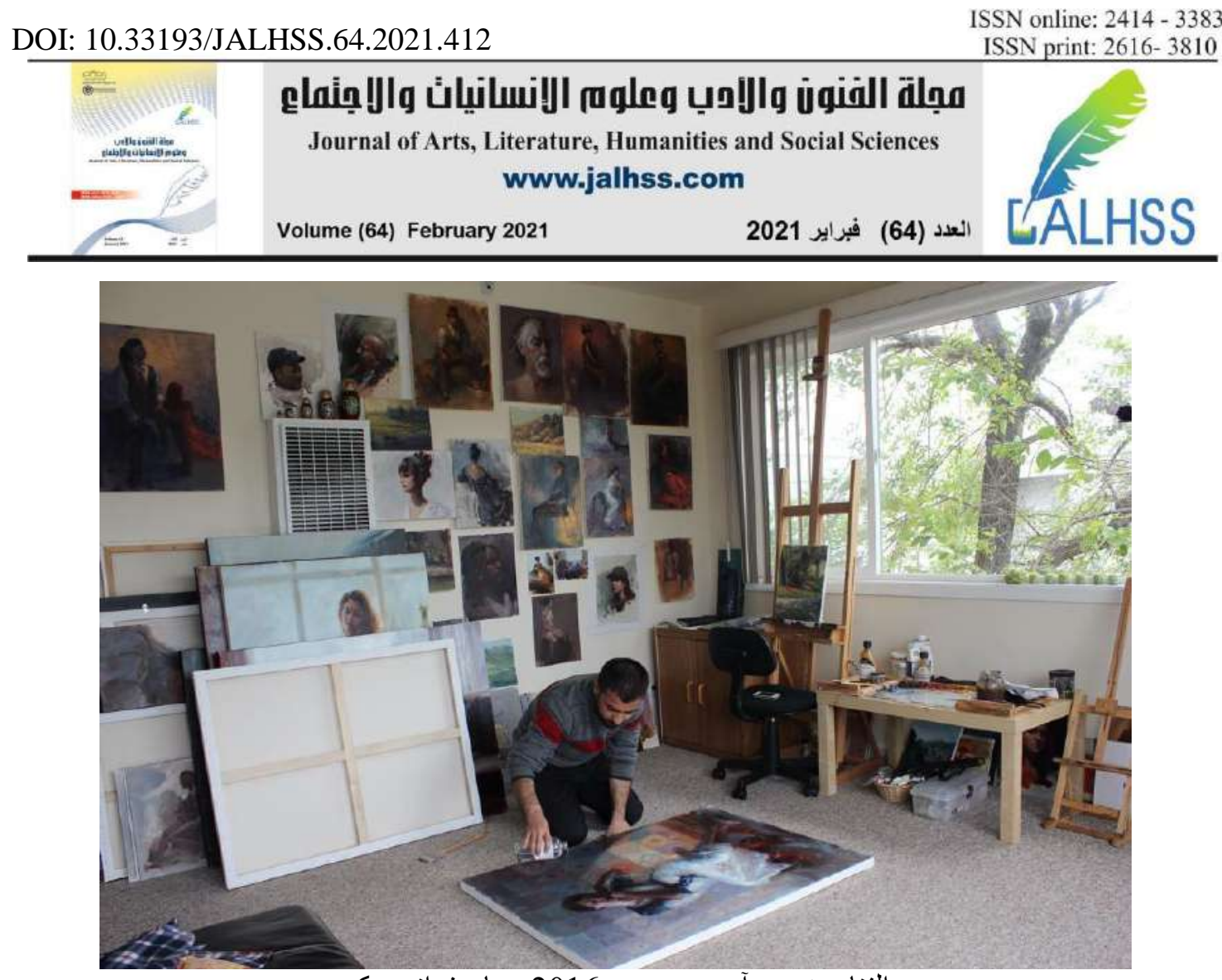

الفنان خيري آدم - مرسم - 2016- سان فر انسيسكو

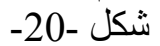

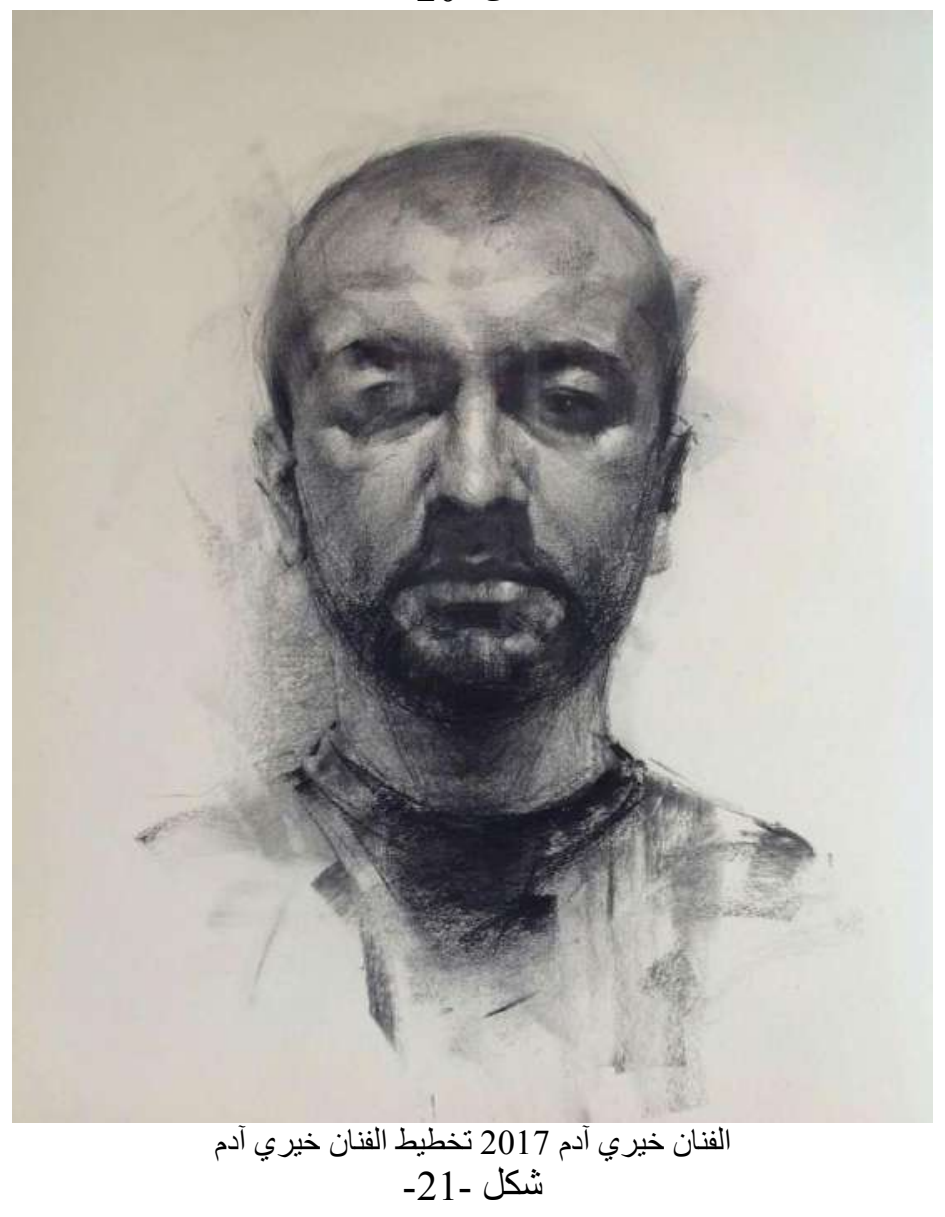




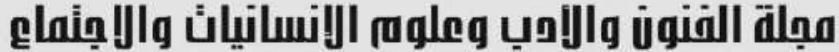 \\ Journal of Arts, Literature, Humanities and Social Sciences www.jalhss.com

شرف للملصقي عام 2001، وشارك في معرض مصنع معلبات، سان فرانسيسكو، سي أي بمعرض منفرد

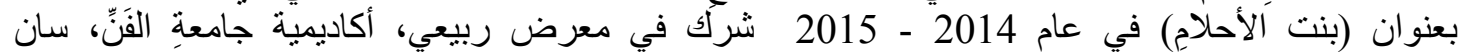

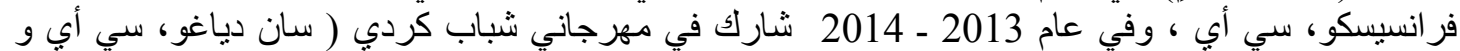

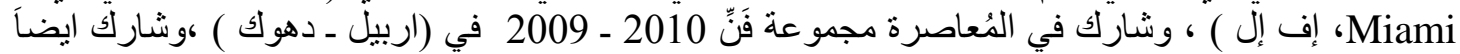

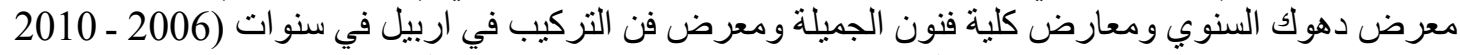

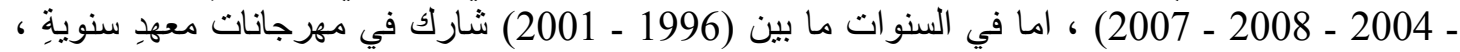

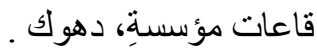

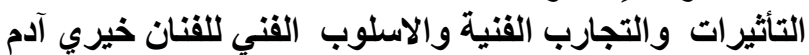

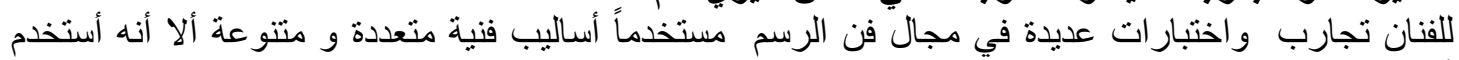

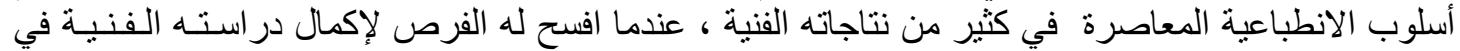

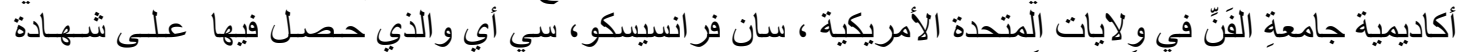

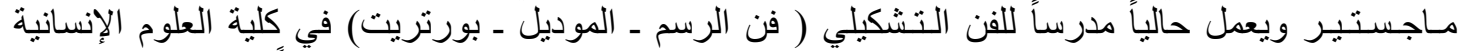

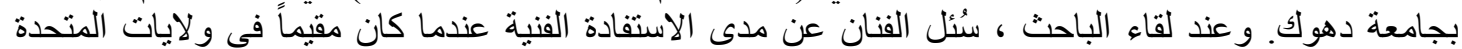

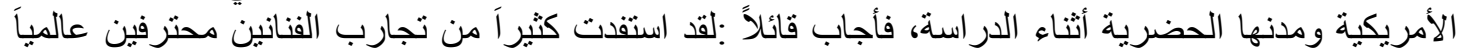

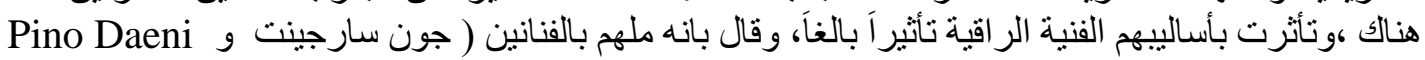

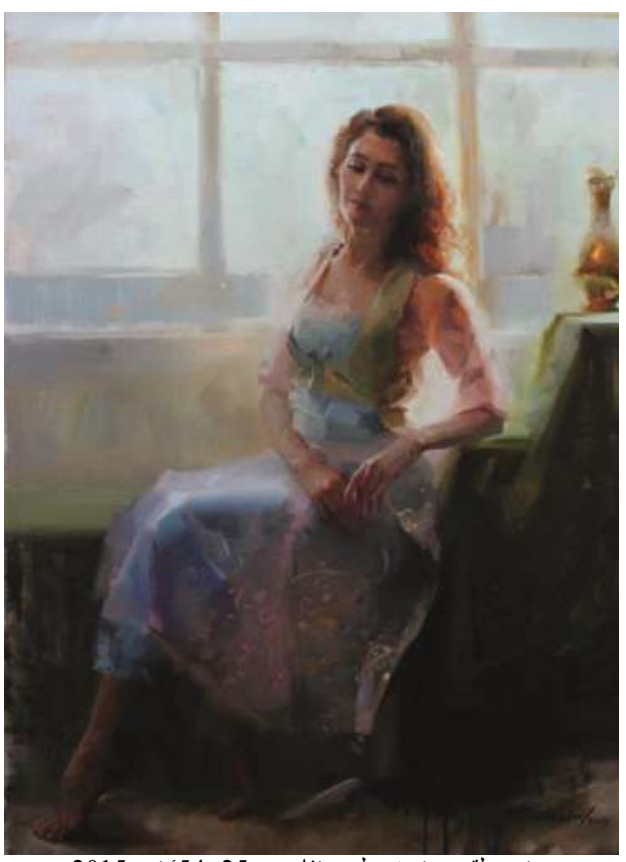

خيري -غير ملقب- زيت على جنفاص- 25×54ينينج- 2015

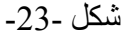

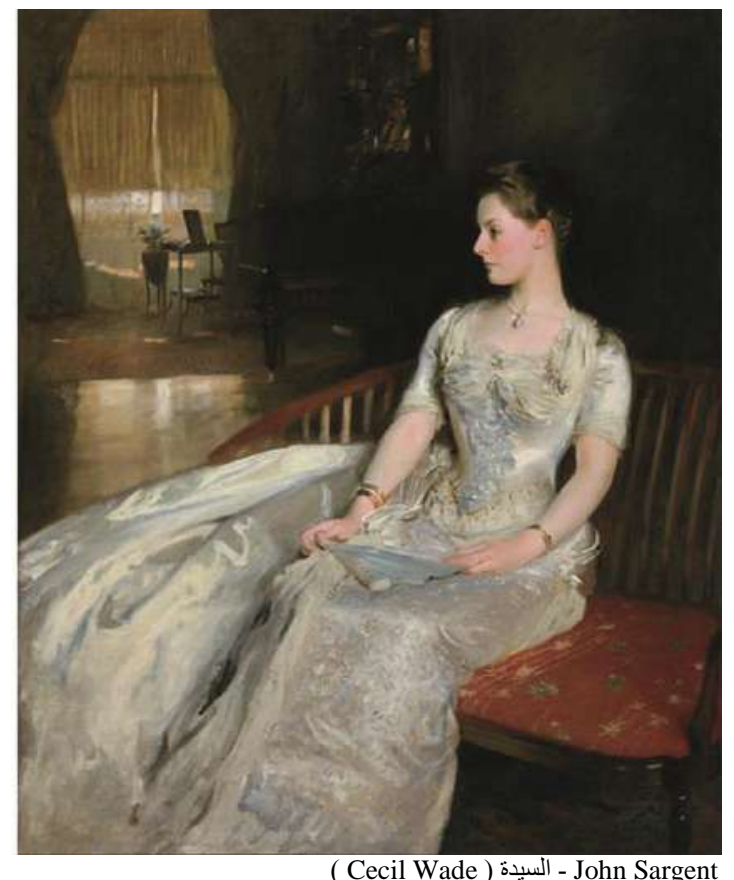

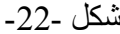

سكوت بورديك و ريتشارد جونسون Richard Johnson ، وكان هؤلاء الفنانين الذين كانو ا بهتمون بالنساء

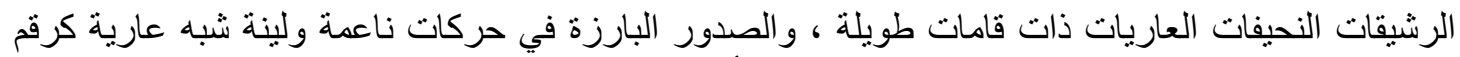

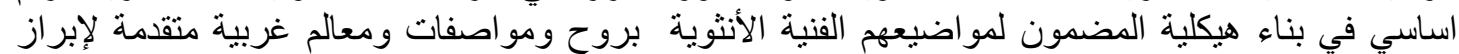

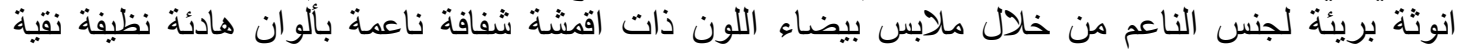

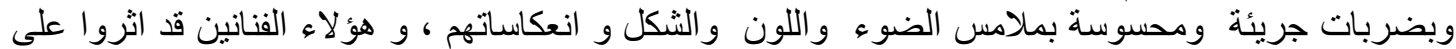

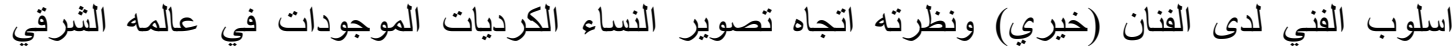

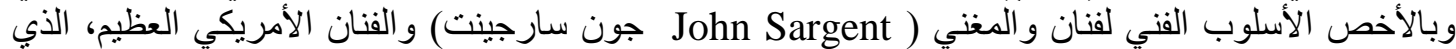

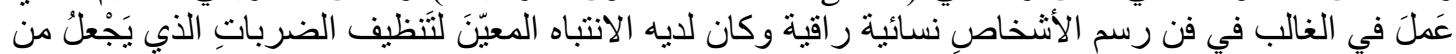




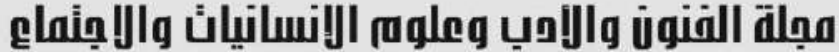 \\ Journal of Arts, Literature, Humanities and Social Sciences www.jalhss.com

لوحاته اكثر تعبيراً بواسطة brushstrokes ويُمْكِنْك أَنْ نَرى العديد مِنْ brushstrokes الجريء مختلفةً

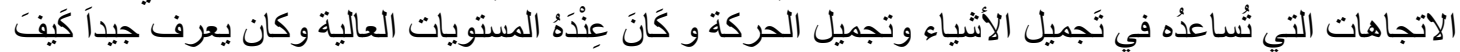

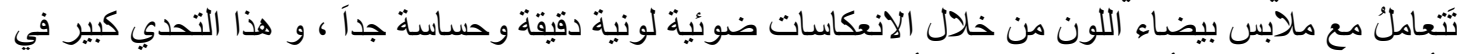

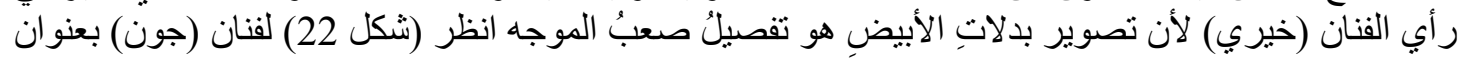

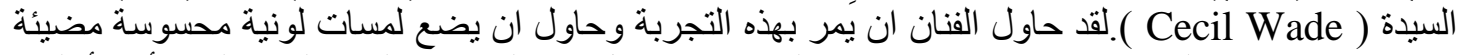

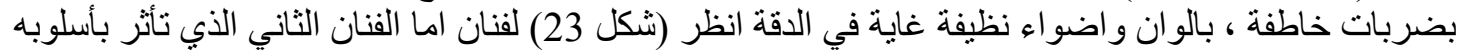

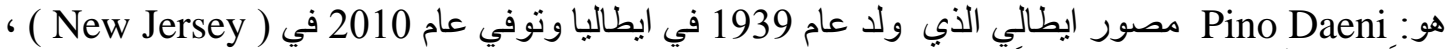

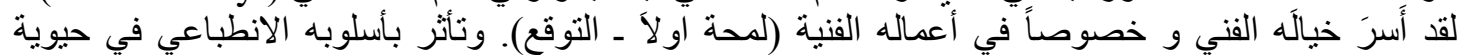

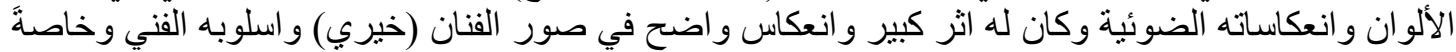

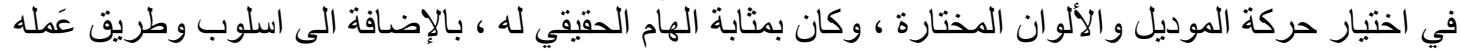

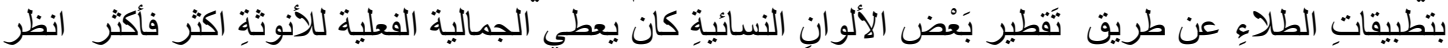

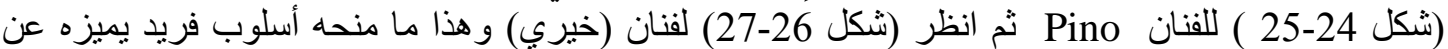

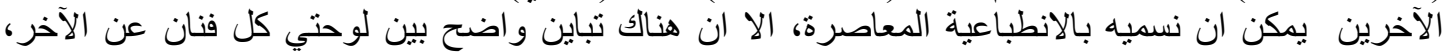
فالأضو اءو والألوان في لوحتي Pino اقوى واوضئ لونح و انظف مقارنة بلوحتي الفنان خيري.
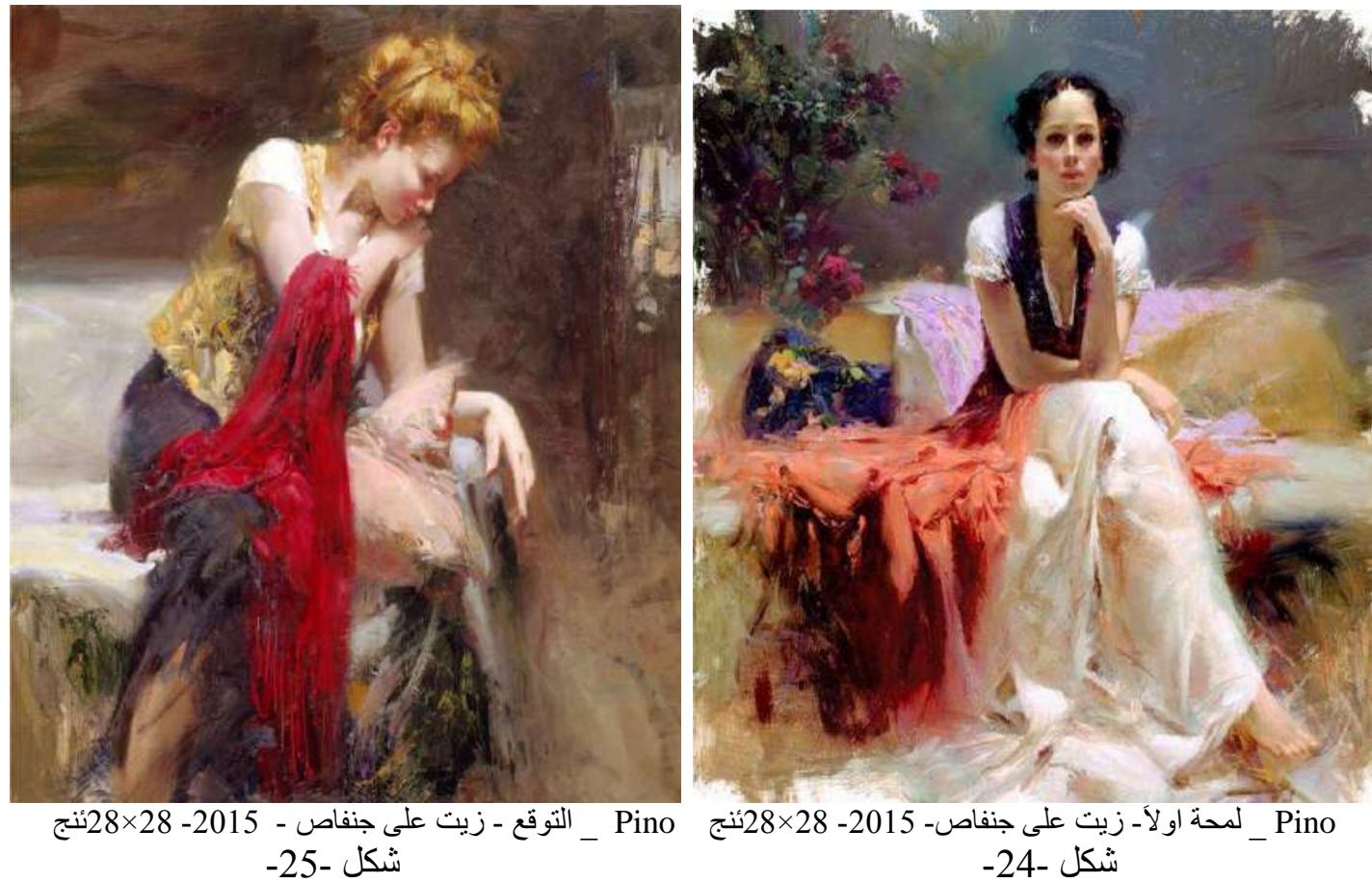

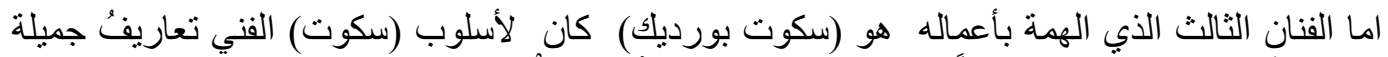

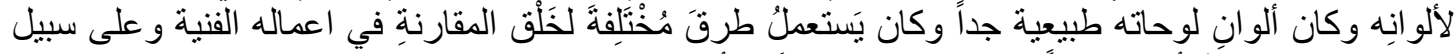

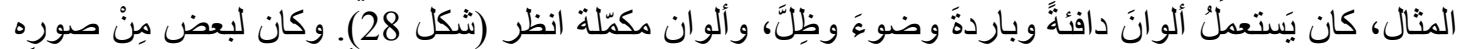

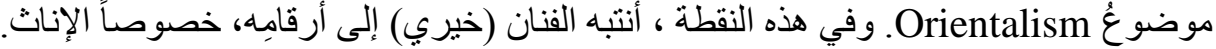



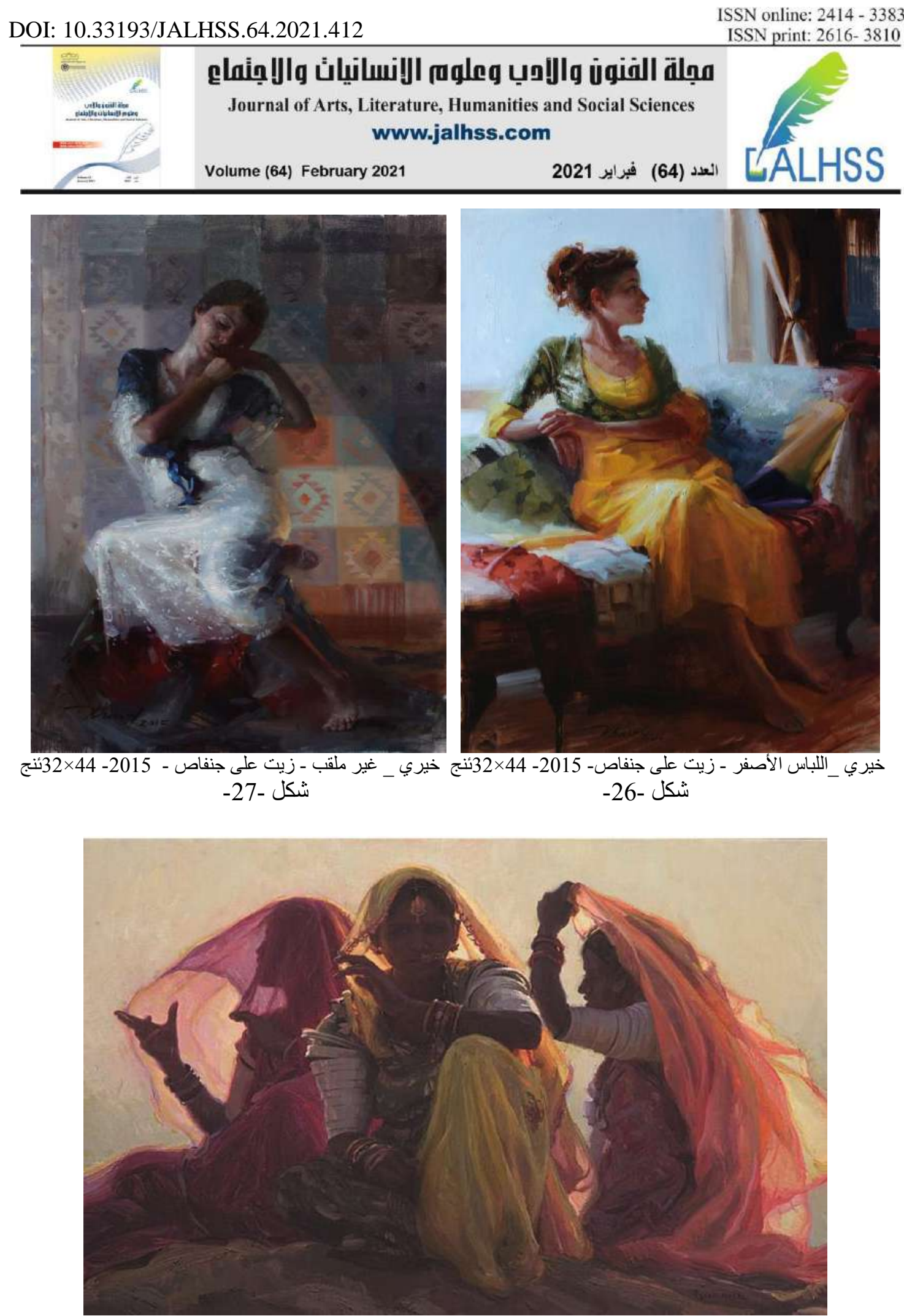

سكوت بورديك

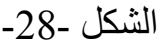

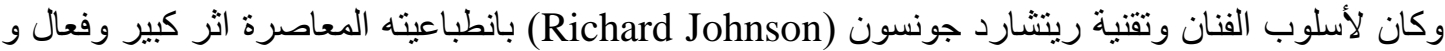

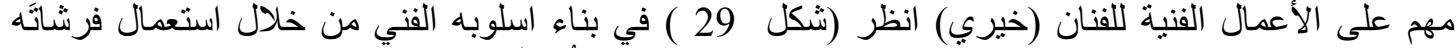
الر اقصةُ المتذبذبة منطايرة الضربات عريضة شكل على الجنفاصِِ وتُلوّينُ طائر في جميع الاتجاهات المختلفةٍِ 

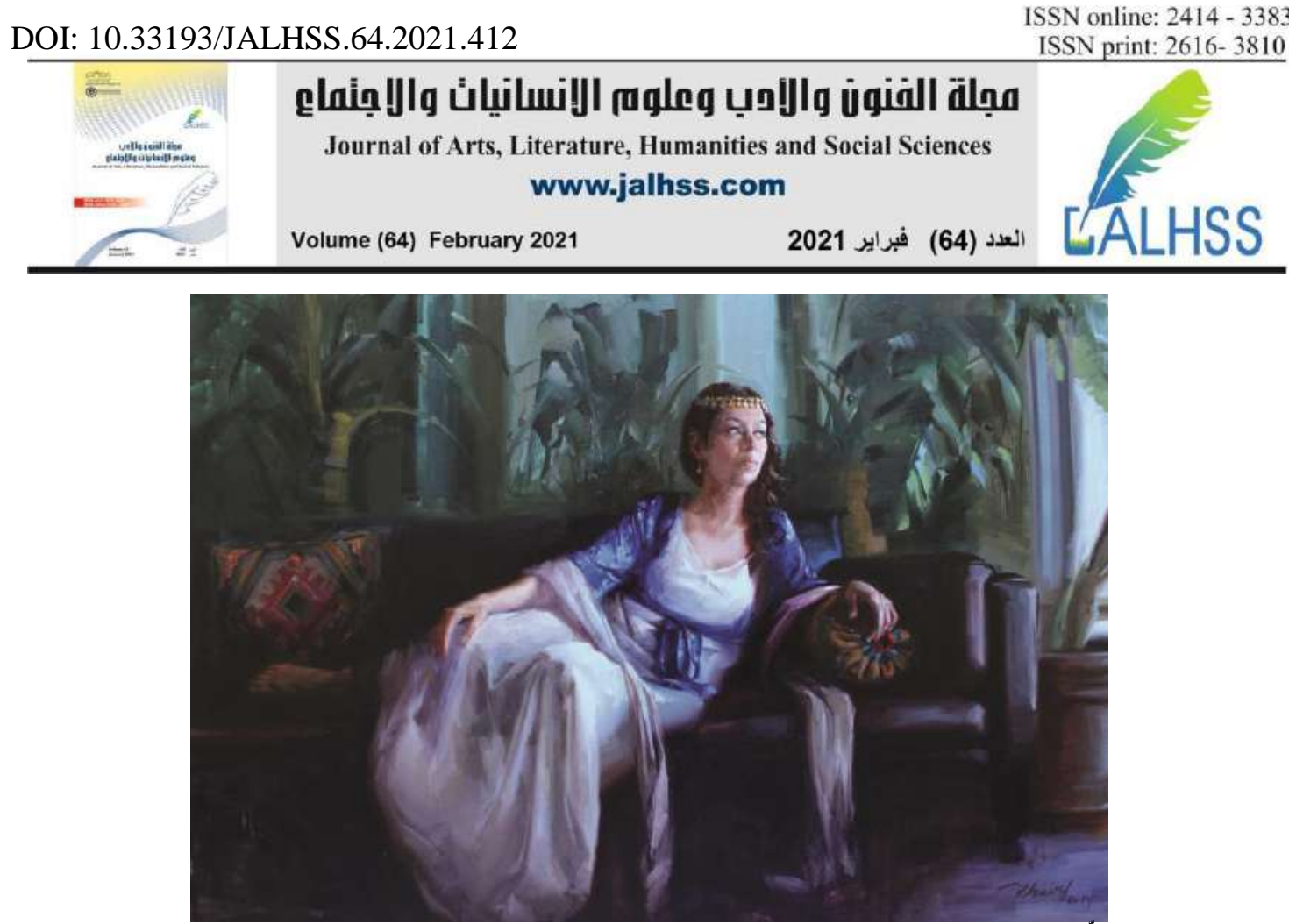

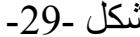

خيري - غير ملقَب - 32×46ئنج زيت على جنفاص- 2014

متدفقة على سطح تصويري في انتاج اعماله ، كما فعله الفنان ريتشارد جونسون و و خصوصاً في الخلفيةِ

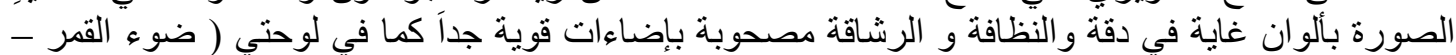

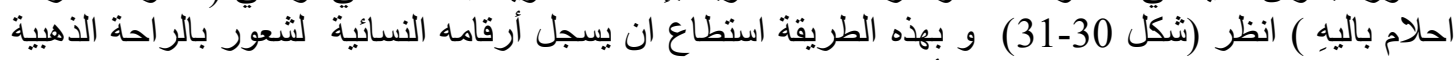

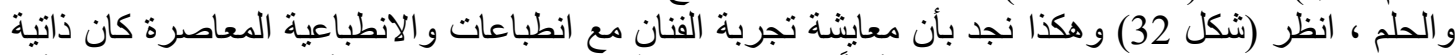

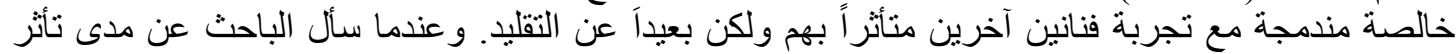

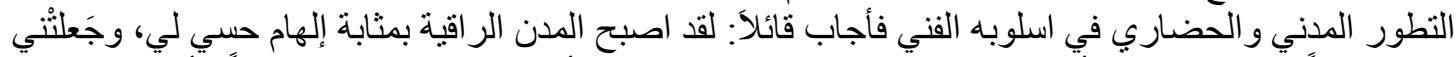

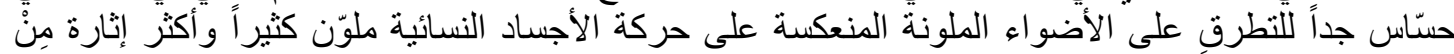

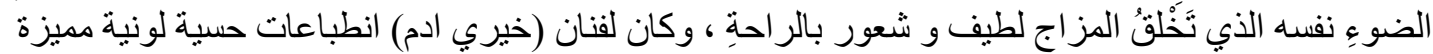

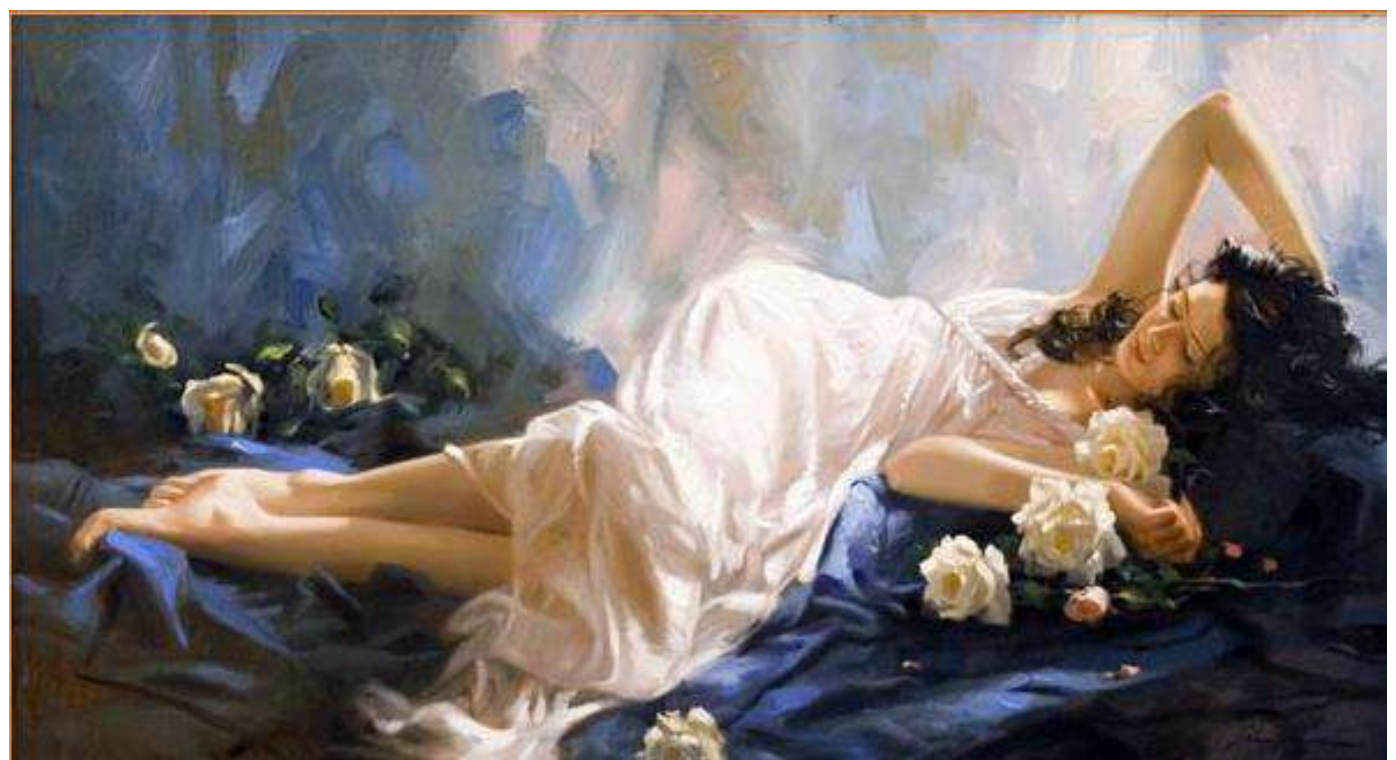

ريتشارد جونسون - ضوء القمر - زيت على جنفاص - 28×50ئنج - 2012

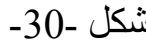




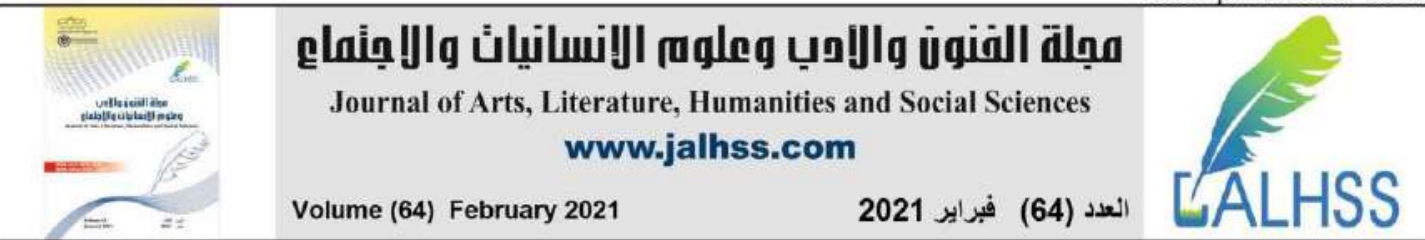

كأسلوب فني معين ، و حاول من خلالها أن يسجل إحساساته المرئية للأجساد لؤلؤية انثوية البريئة من خلال

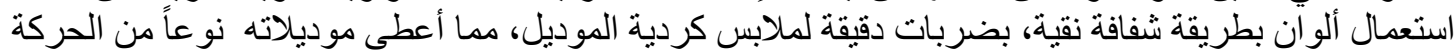

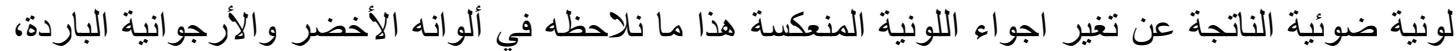

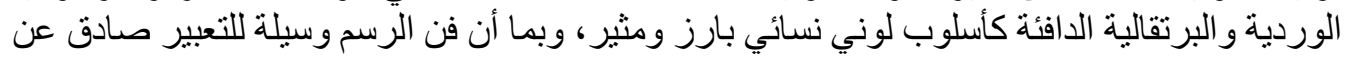

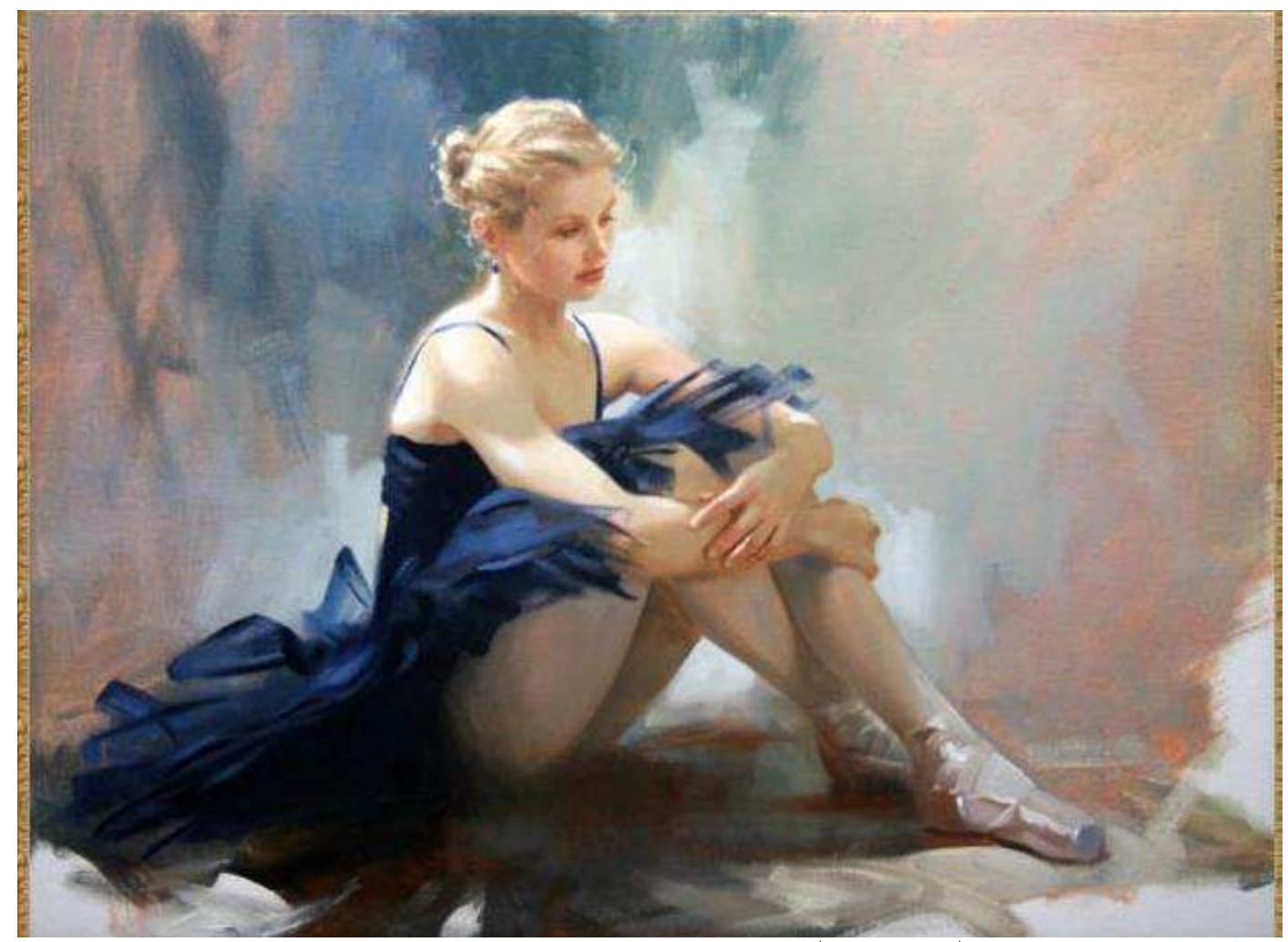

2012 - ريتشارد جونسون ـاحلام باليهِ - زيت على جنفاص - 18 24ئنج شكل -31-

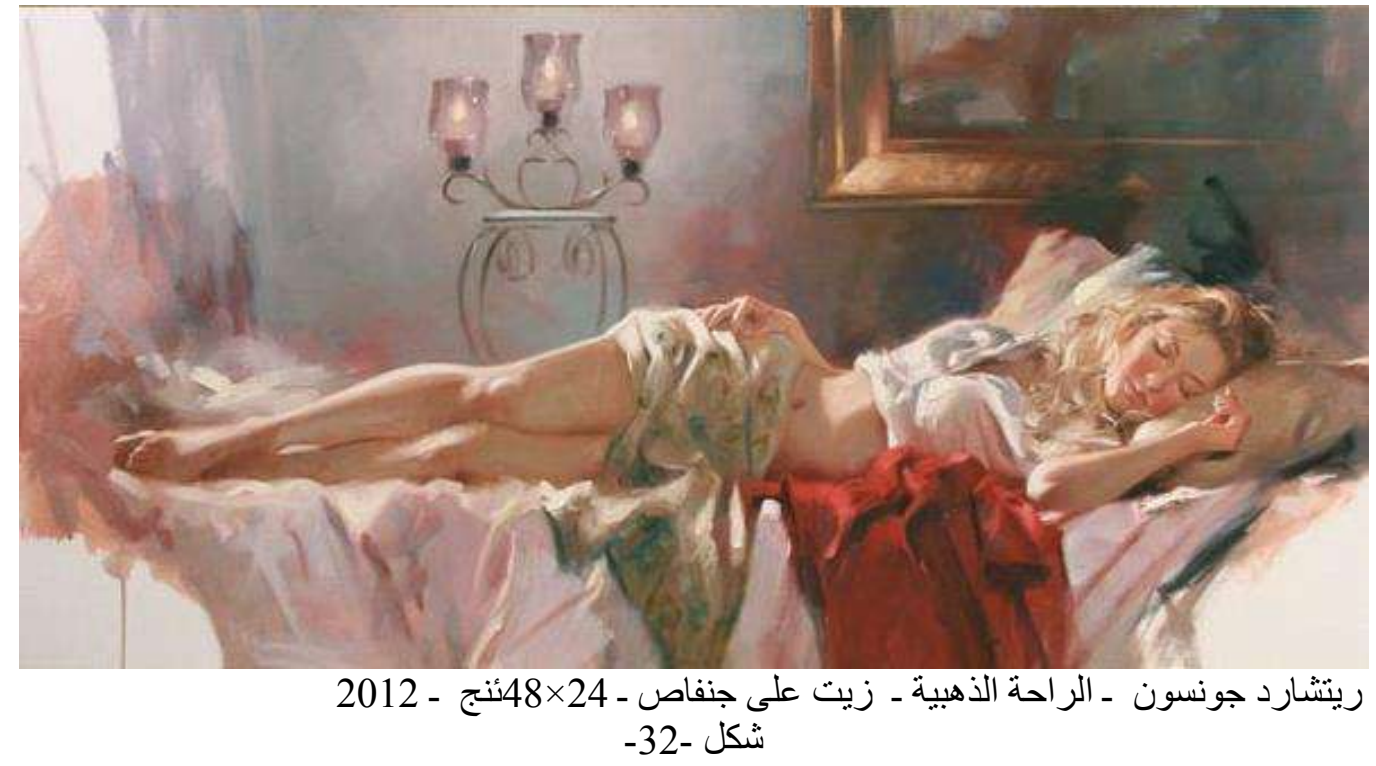




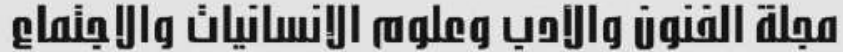 \\ Journal of Arts, Literature, Humanities and Social Sciences www.jalhss.com

الأنوثة نسائية هادئة و عن طريق أحاسيس ضوئية ملونة لرسم وجوه واجسام نسائية رقيقة على سطح تصويري

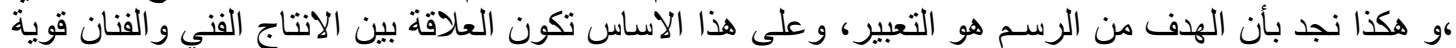

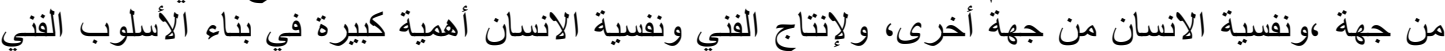

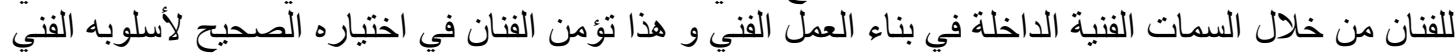

في مدرسة فنية معينة. 12 - 12 تحليل العينات: 12

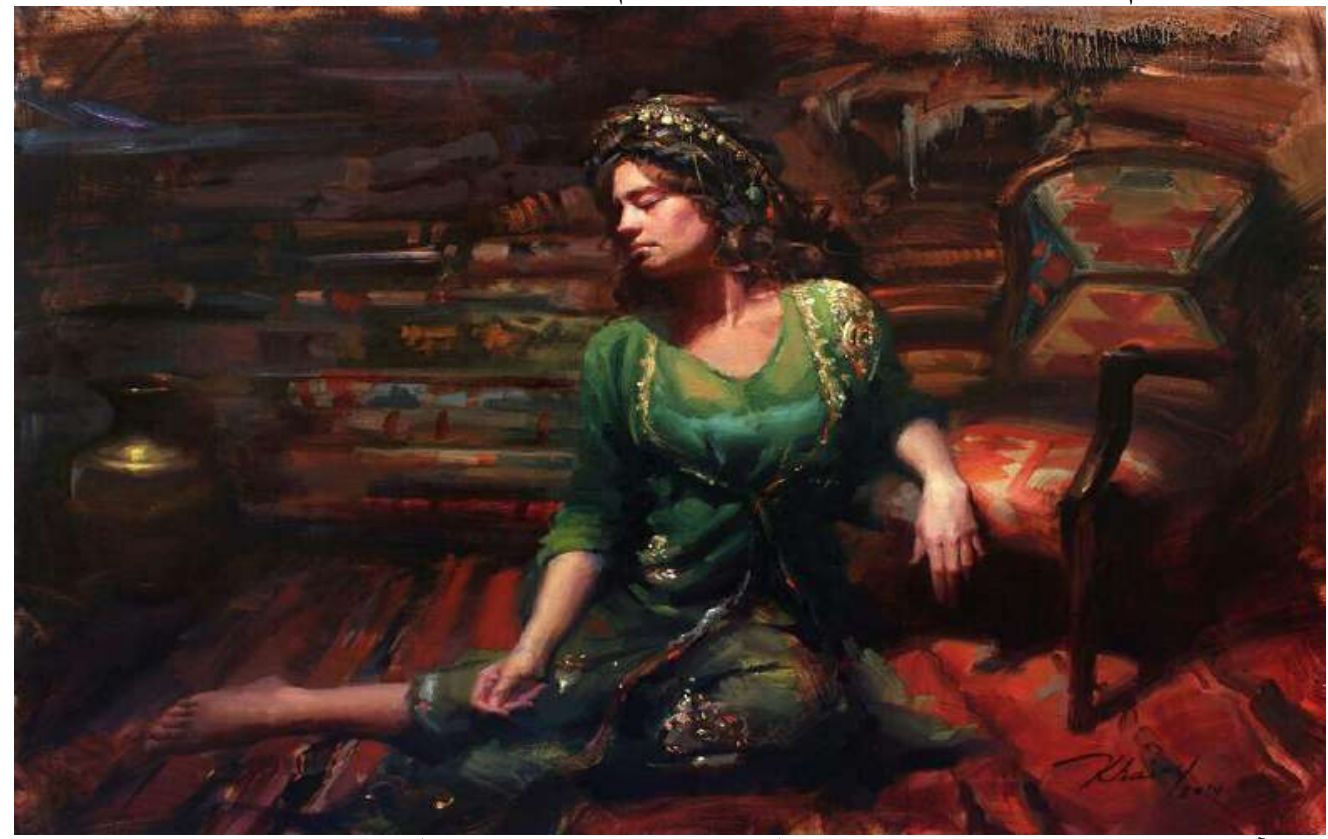

خيري آدم- بنت الاحلام - 32 ×44 ئنج - زيت على جنفاص - 2014 - ارشيف الفنان

رسم الفنان في مساحة مستطيلة أفقية الشكل ،بأبعاد 32×44ئنج و بمادة الزيت على الجنفاص انطباعات حسية

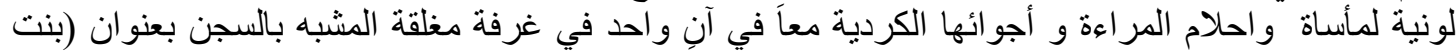

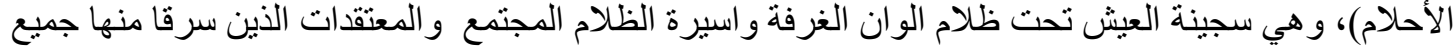

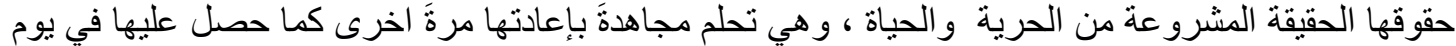

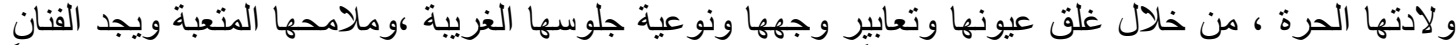

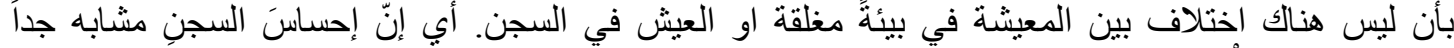

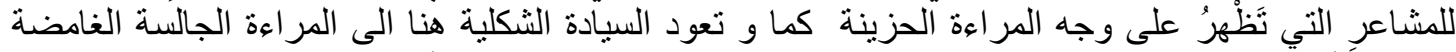

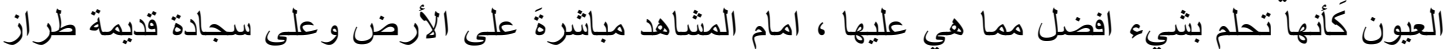

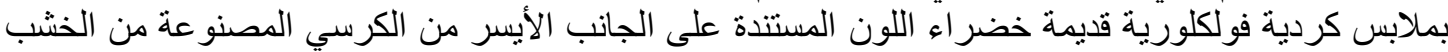

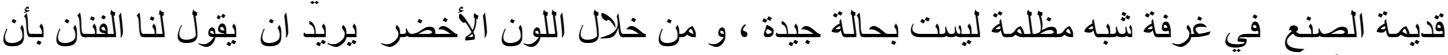

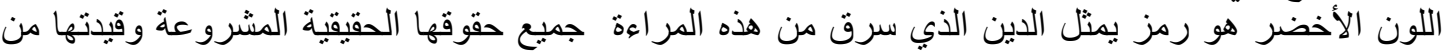

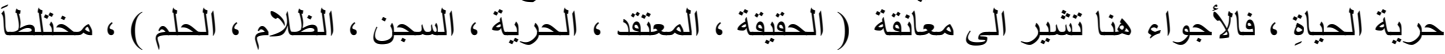

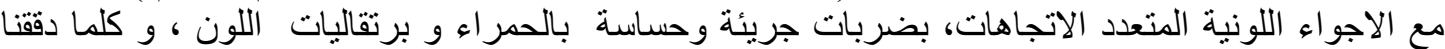

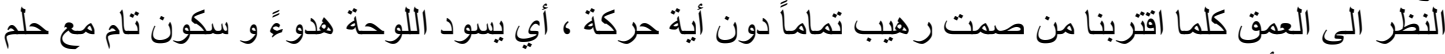

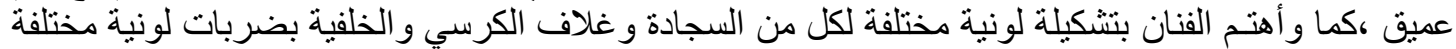

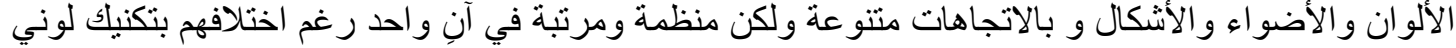

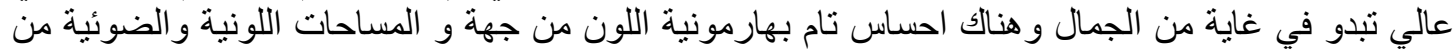
جهة" أخرى و المساحات الضالالية التي خلقت سمفونية من اللون كأنها سمفونية لونية كردية ذات انغام متداخلة 


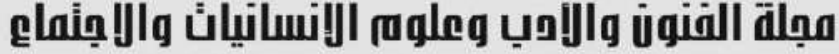 \\ Journal of Arts, Literature, Humanities and Social Sciences www.jalhss.com

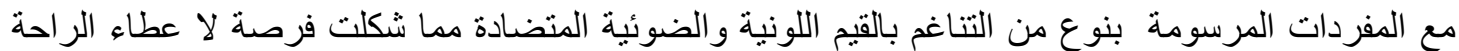

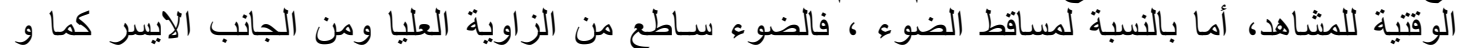

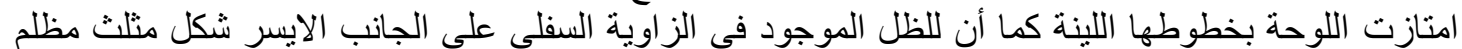

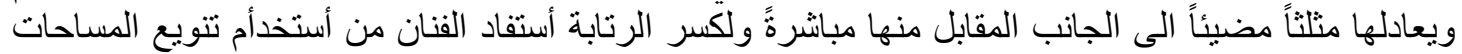

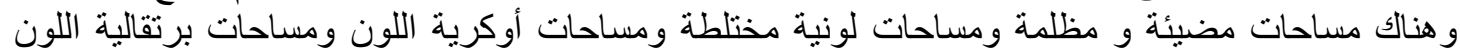

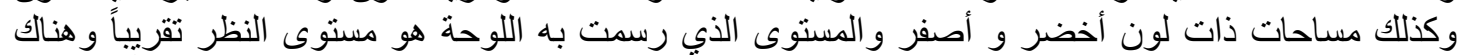

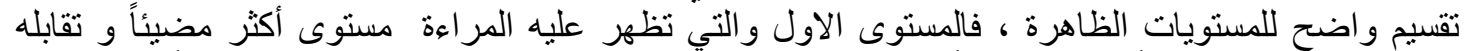

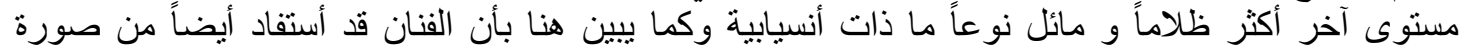

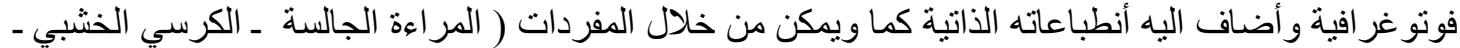

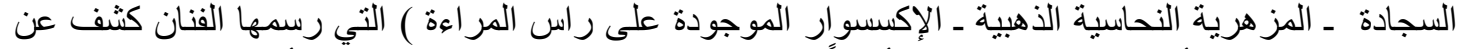

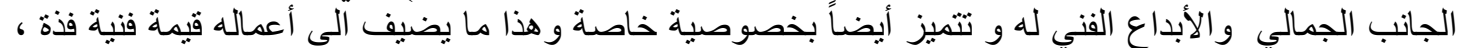

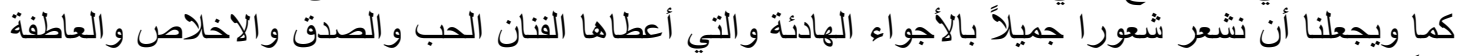

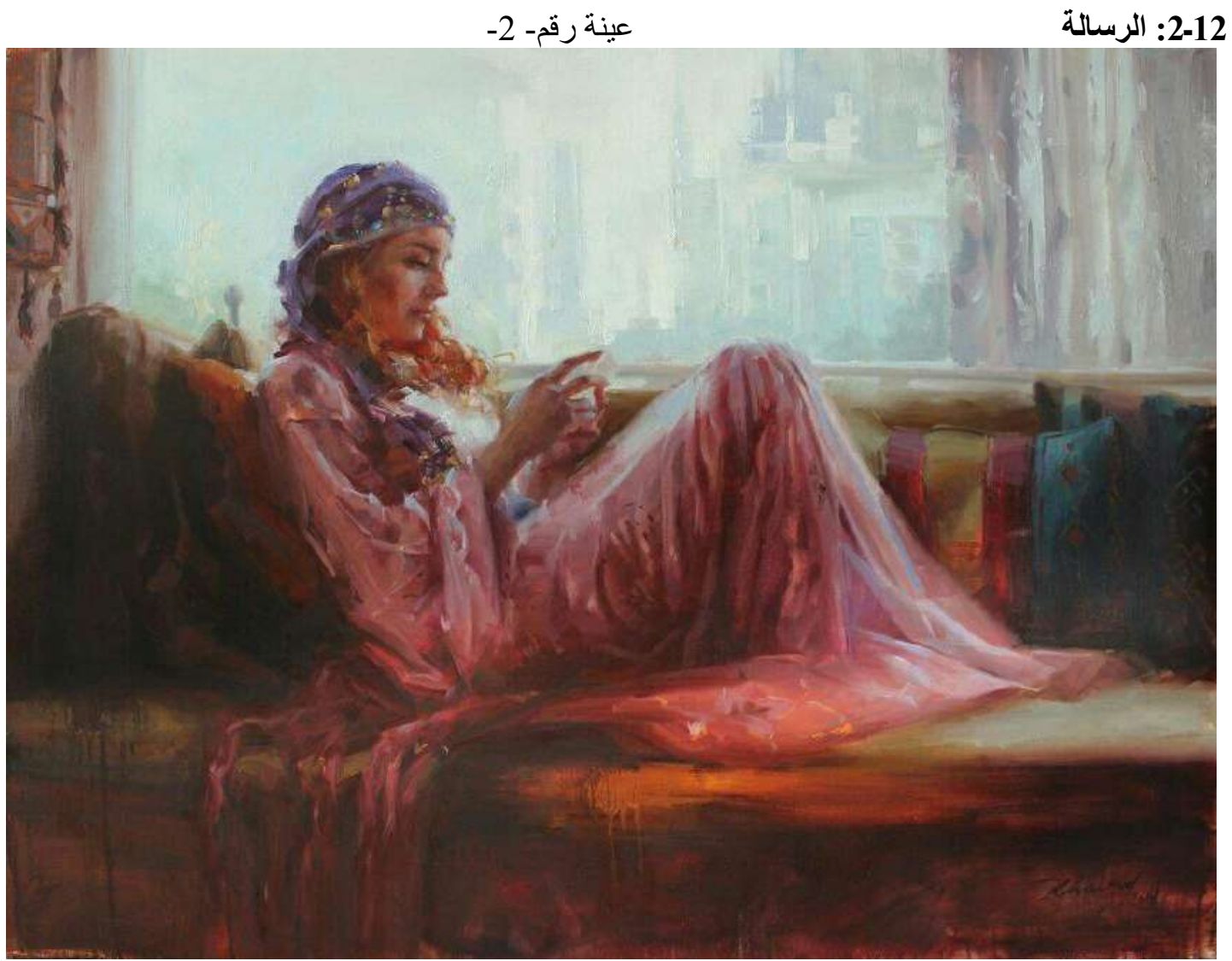

خيري آدم - الرسالة - 32 ننج×44ننج - زيت على جنفاص - 2015 - ارشيف الفنان

على مساحة المستطيلة أفقية الثكل رسم الفنان انطباعاته الوردية الانثوية بعنو ان (الرسالة) المرسوم بمادة زيت

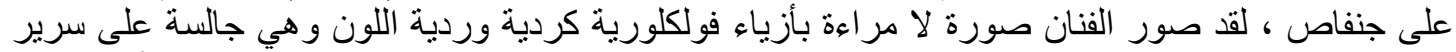

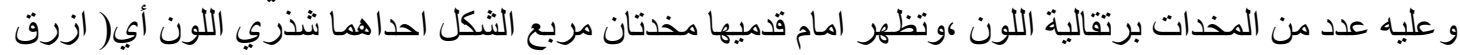

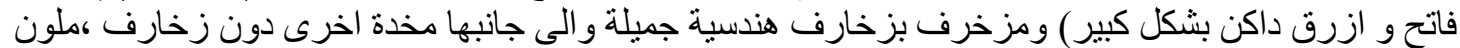

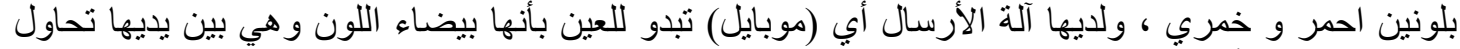

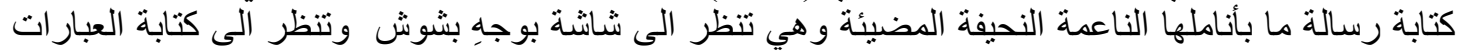




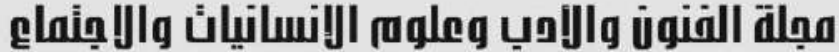 \\ Journal of Arts, Literature, Humanities and Social Sciences www.jalhss.com

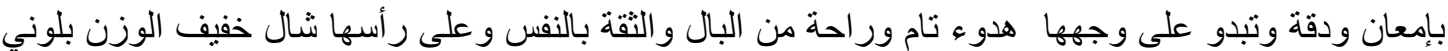

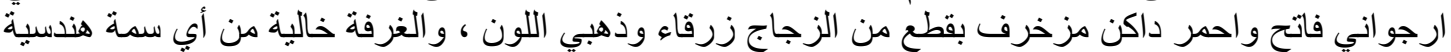

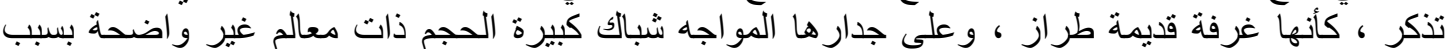

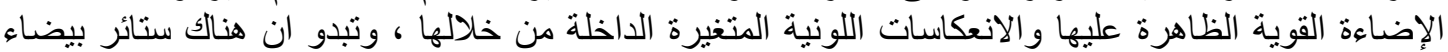

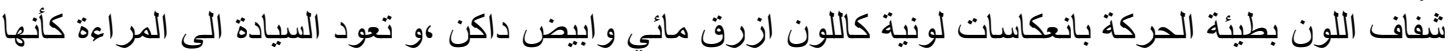

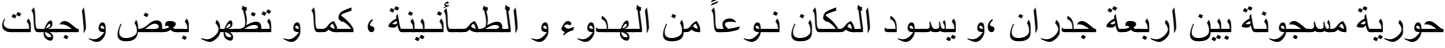

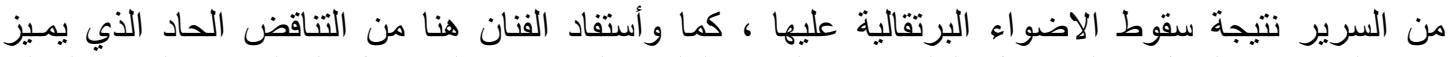

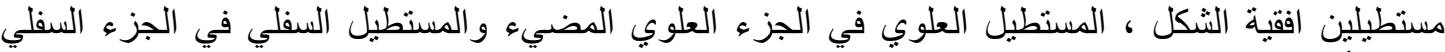

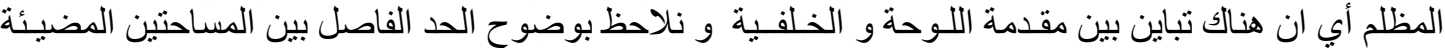

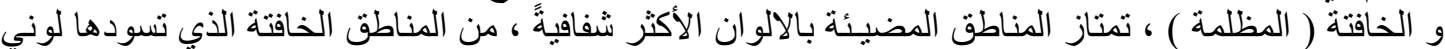

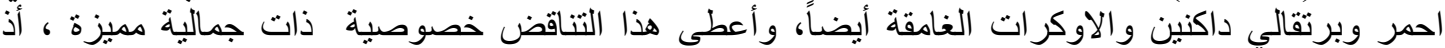

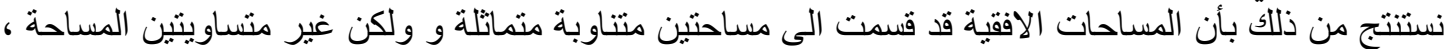

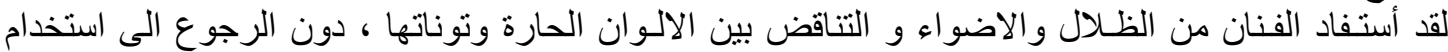

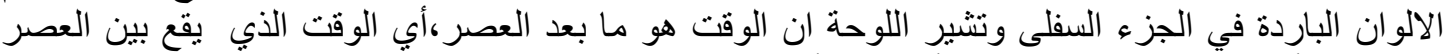

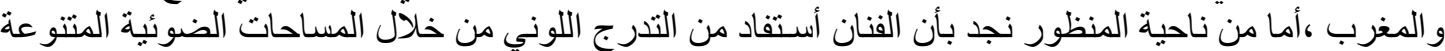

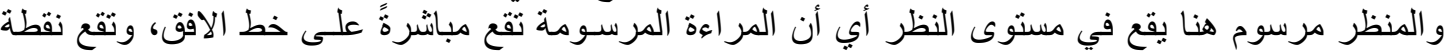

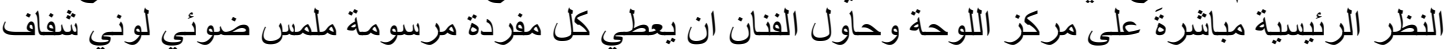

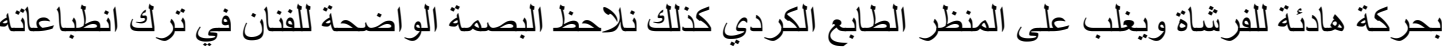

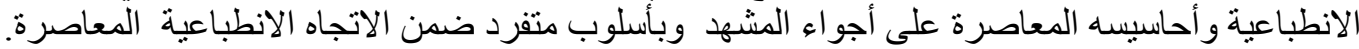

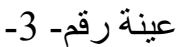

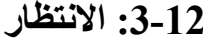

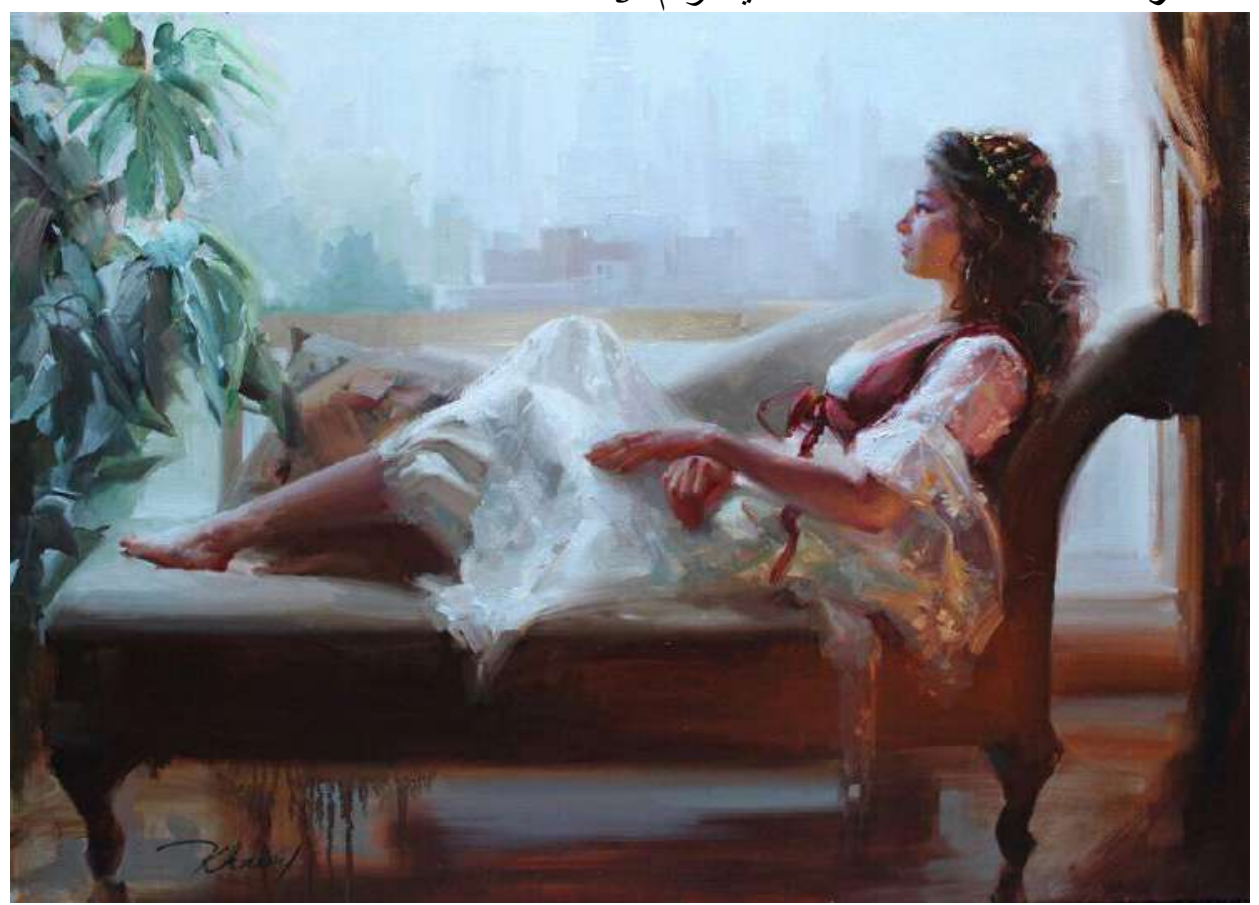

خيري آدم - الانتظار - 32 ئن×44ئنج - زيت على جنفاص - 2014 - ارشيف الفنان

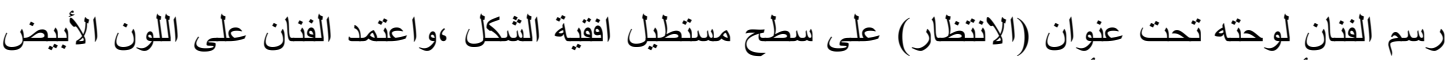

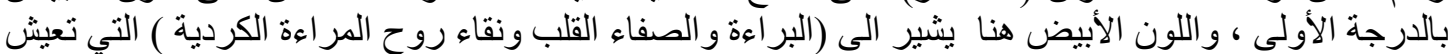

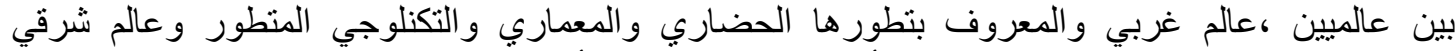

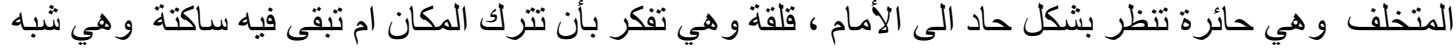




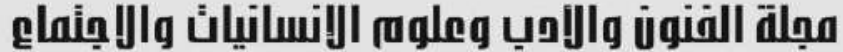 \\ Journal of Arts, Literature, Humanities and Social Sciences www.jalhss.com

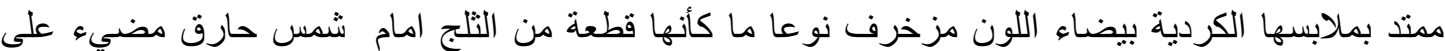

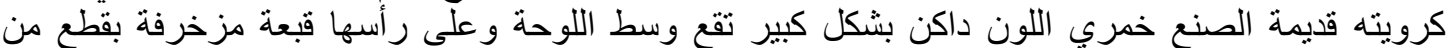

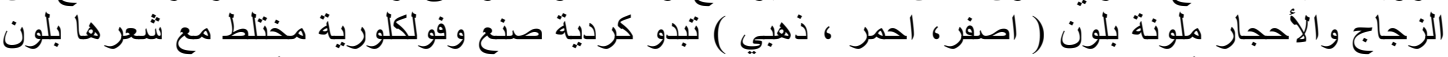

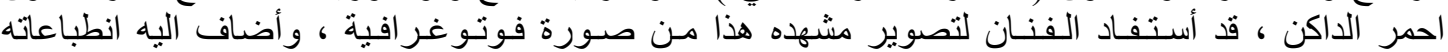

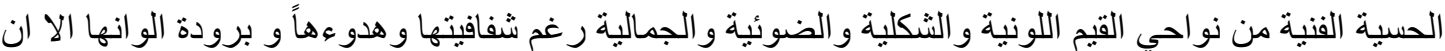

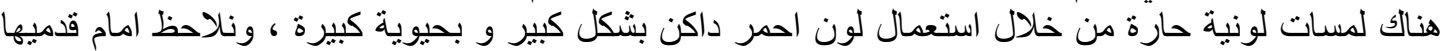

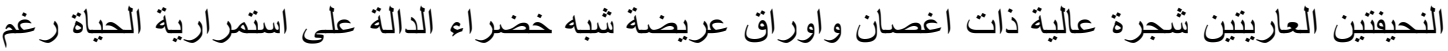

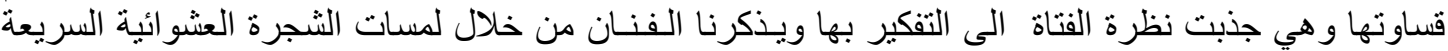

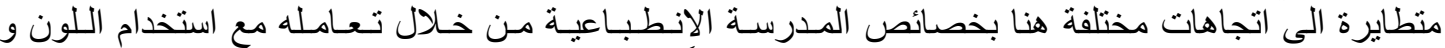

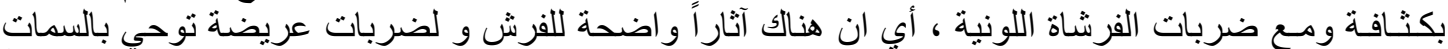

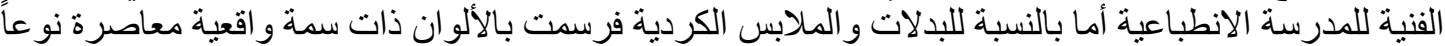

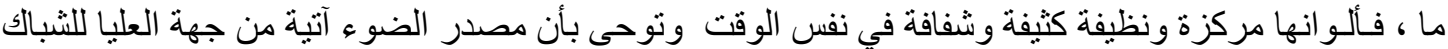

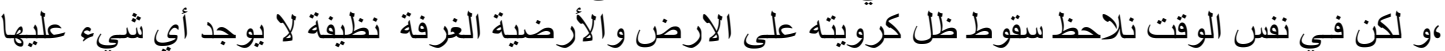

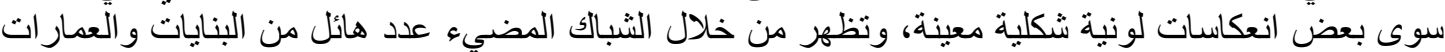

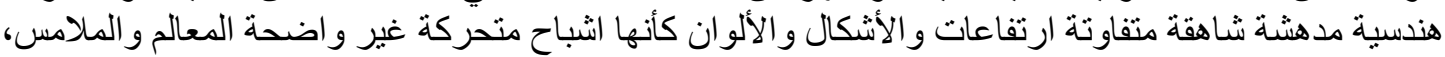

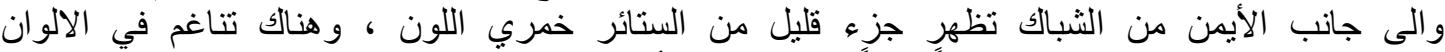

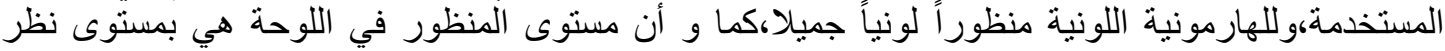

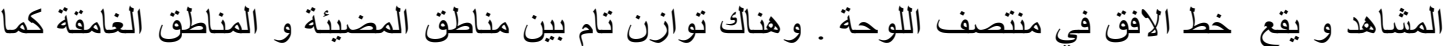

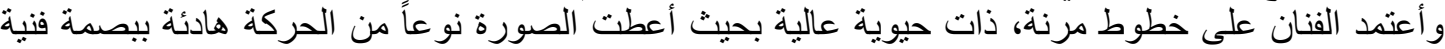

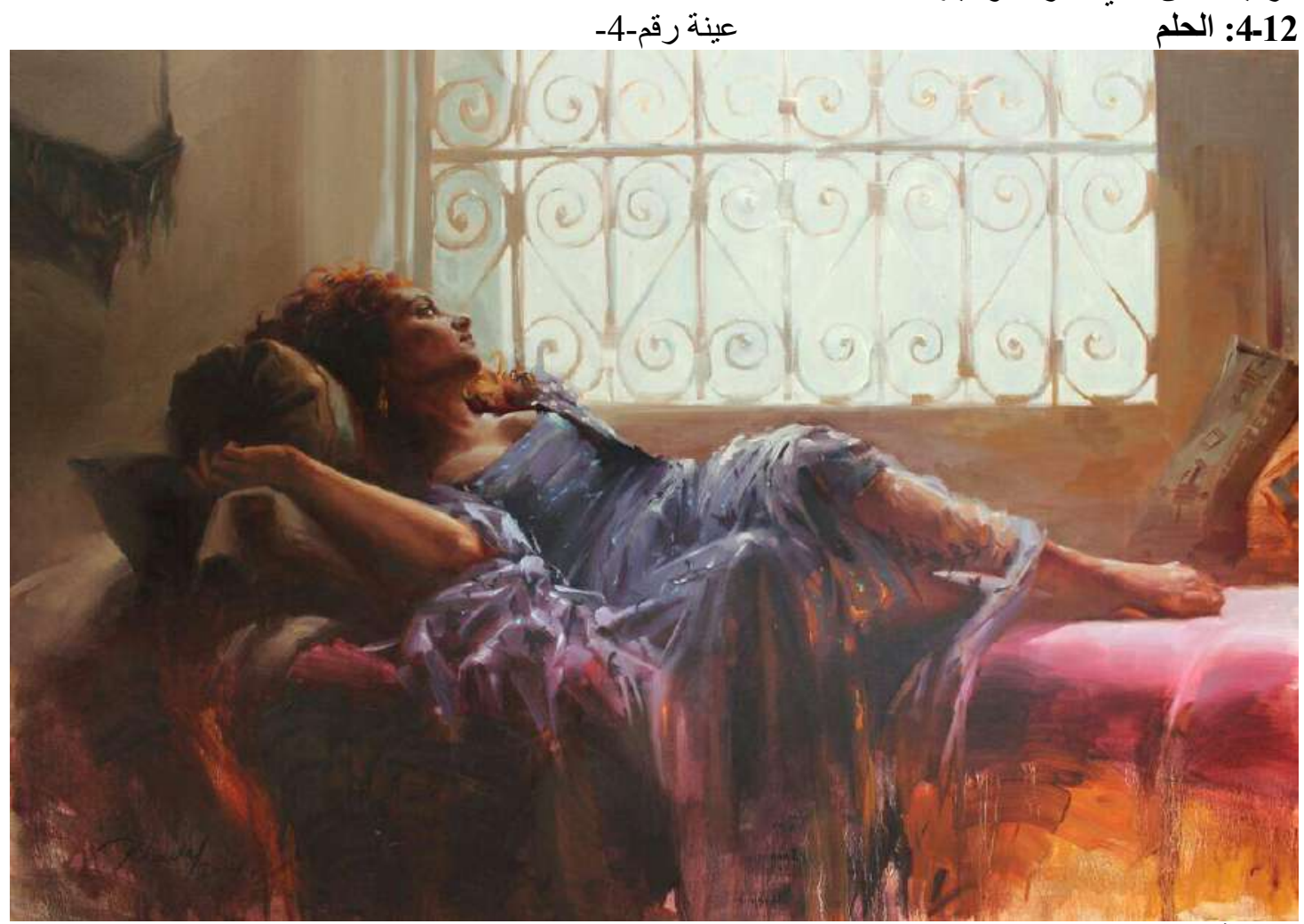

خيري آدم - الحلم - 32 ننج×46ننج - زيت على جنفاص - 2014 - كاليفورنيا 


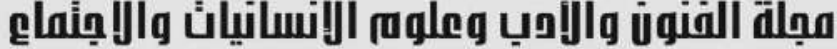 \\ Journal of Arts, Literature, Humanities and Social Sciences www.jalhss.com

على مساحة مستطيلة أفقية الثكل رسم الفنان لوحته التي تحمل عنوان (الحلم)، المرسومة بمادة الزيت على القيل

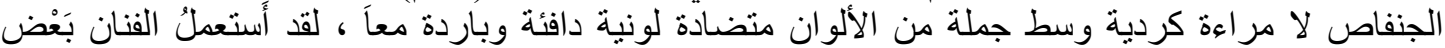

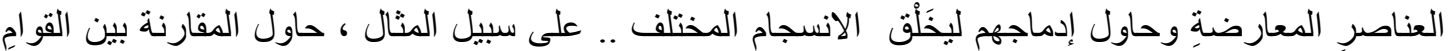

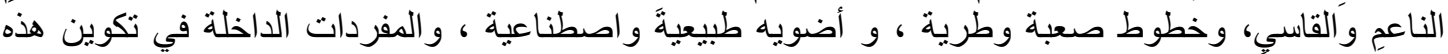

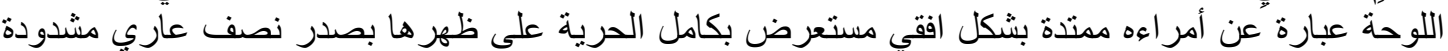

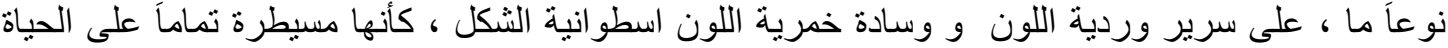

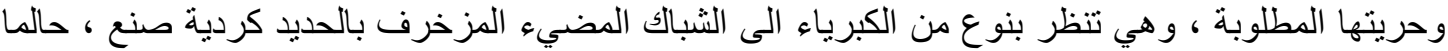

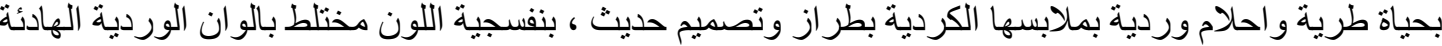

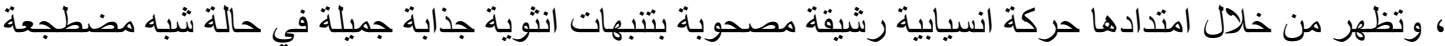

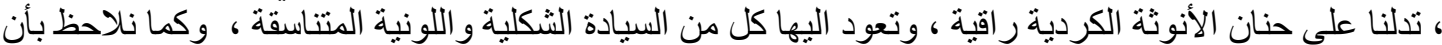

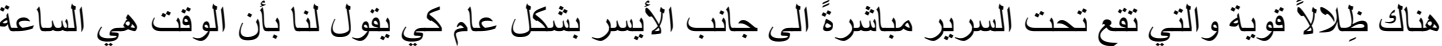

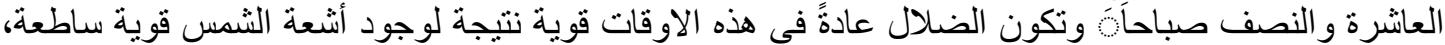

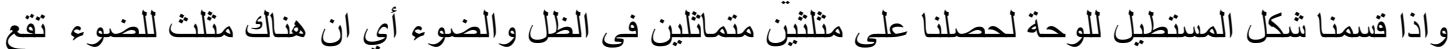

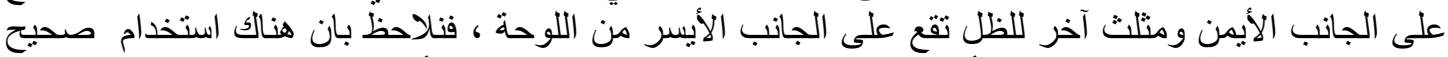

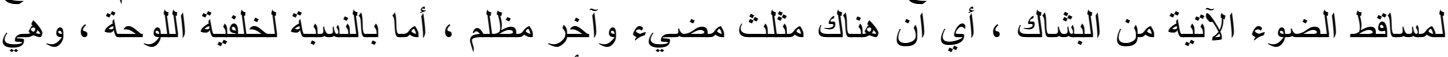

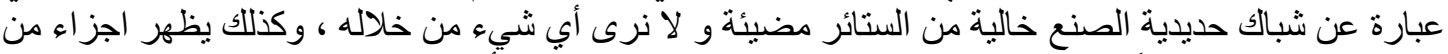

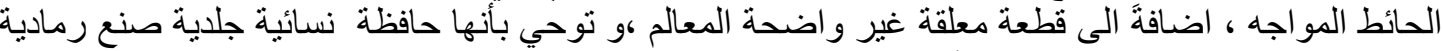

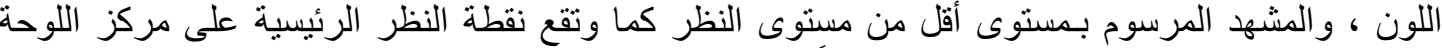

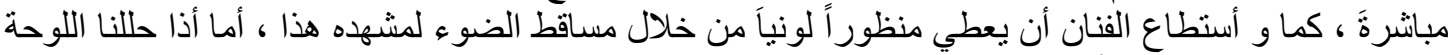

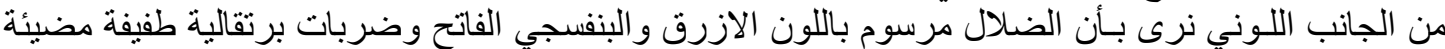

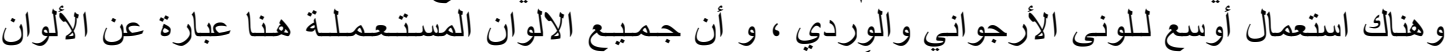

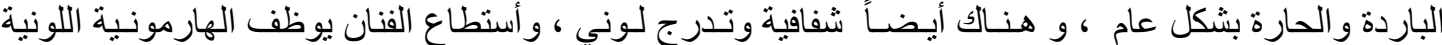

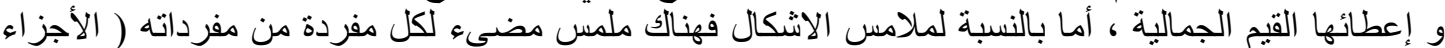

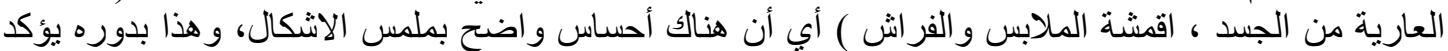

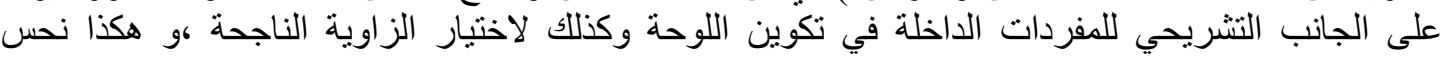

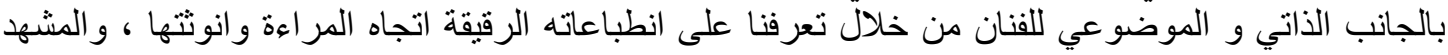

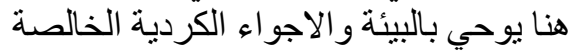

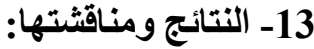

1- كان لخصائص اسلوب الانطباعية ( لمسات عريضة ، بقاء اثار للفرش ، الوان انقان نقية شفافة مضيئة ،

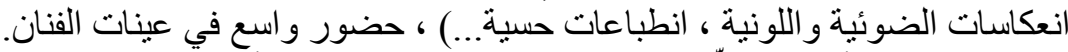

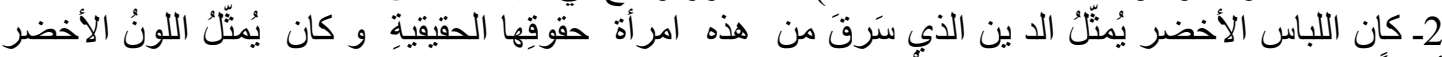

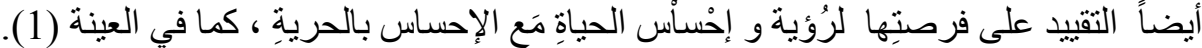

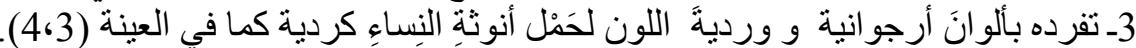

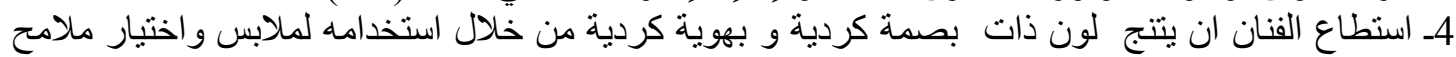

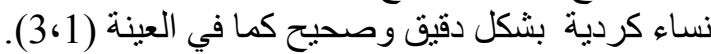

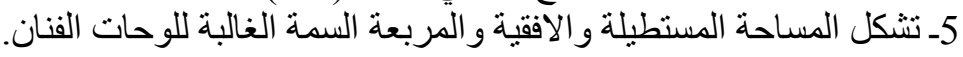

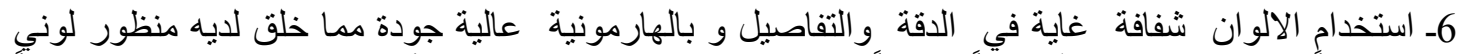

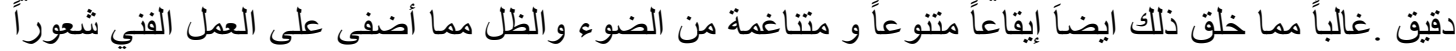

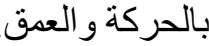
7ـ امتازت الاعمال الفنية بوقعها على مستوى النظر و استخدم خط الأفق كمستوى للنظر بشكل عام في جميع

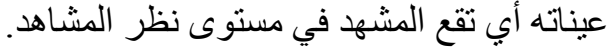

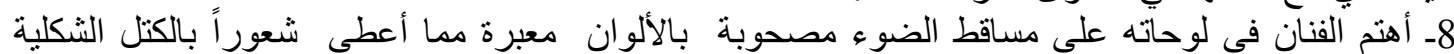

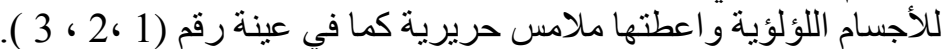
9ـ أمتاز أسلوبه بليونة خطوطه و أنسيابيتها في تحديد الاشكال كما في عينة رقمة (3 ) ، 2 ،4). 


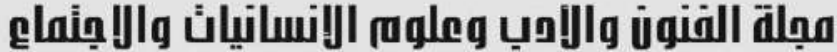 \\ Journal of Arts, Literature, Humanities and Social Sciences www.jalhss.com

10- رسم المراءة الكردستانية بملابس كردية فولكلورية في أغلب لوحاته محافظاً على روحهاو جمالياتها

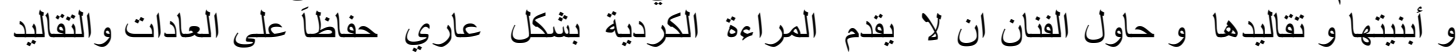

1 - إن لوحات الفنان قد عبرت في أسلوبها على ابراز انوثة اجساد من خلال ملابس المراءة الكرديةو 2- المقأ أسلوب الفنان بقع ضمن أتجاه الانطباعية المعاصرة.

يقترح الباحث القيام بدراسة أساليب الفنانين آخرين من كردستان، مثل الفنان( شيرزاد كنجو و بشدار نوري) وآخرون غير هم كان لهم أهمية في الحركة التشكيلية الكوردية. 16- 16 - 1التوصيات يوصي الباحث طبع هذه الدر اسة لتوثيق الحركة الفنيـة في اقليم كردستان/العر اق.

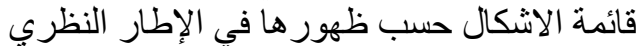

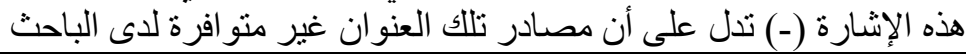

\begin{tabular}{|c|c|c|c|c|c|}
\hline عائديه العمل / سنة الإنجاز & القياسات & 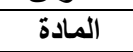 & موضوع اللوحة & اسم الفنان و هويته & $ت$ \\
\hline $\begin{array}{l}\text { ارشيف الباحث } 2017 \\
\end{array}$ & 15×20 15سم & فوتوغراف & اخناتون & فنان مصري غير معروف & 1 \\
\hline ارشيف الباحث & 15×015سم & فوتوغر اف & تتويج الفر عون & فنان مصري غير معروف & 2 \\
\hline ارشيف الباحث & 15×015سم & فونوغراف & فيفرتيتي زوجة & فنان مصري غير معروف & 3 \\
\hline تيت غاليري لندن & 213×269 سم & زيت على زئ & اولمبيا & 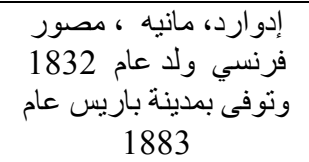 & 4 \\
\hline قان & - & زنفاص على & فينوس نائمة & 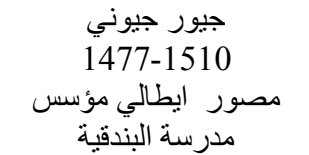 & 5 \\
\hline ارشيف الفنان & - & زنفاص على & $\begin{array}{l}\text { Sensuality } \\
\text { الثهوانية }\end{array}$ & $\begin{array}{c}\text { Pino Daeni } \\
\text { مصور ايطالي ولد عام } 1939 \text { ونوفي } 2010 \text { مالم New Jersey United } \\
\text { stutes }\end{array}$ & 6 \\
\hline ارشيف الفنان & - & زيت على زئ & $\begin{array}{c}\text { Soft-light } \\
\text { ضو } \\
\text { لطو }\end{array}$ & $\begin{array}{l}\text { Pino Daeni } \\
\text { مصور ايطالي }\end{array}$ & 7 \\
\hline $\begin{array}{c}- \\
1878\end{array}$ & - & زيت على زلف & المكسو & فر انسسكو دي غوريا & 8 \\
\hline $\begin{array}{c}- \\
1878\end{array}$ & - & زيت على جنف & العاري & فرانسسكو دي غويا & 9 \\
\hline - & - & زيت على زئ & النوم & $\begin{array}{c}\text { Serge Marshennikor } \\
\text { مصور روسي }\end{array}$ & 10 \\
\hline- & - & زيت على زلفاص & 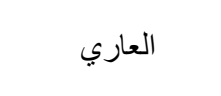 & $\begin{array}{c}\text { Serge } \\
\text { مصور روسي }\end{array}$ & 11 \\
\hline $\begin{array}{c}- \\
1880\end{array}$ & - & زيت على زيص & العارية الزرقاء & $\begin{array}{l}\text { Pierre -Auguste - } \\
\text { ، أو غست رينوار noir }\end{array}$ & 12 \\
\hline
\end{tabular}




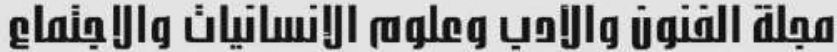

Journal of Arts, Literature, Humanities and Social Sciences www.jalhss.com

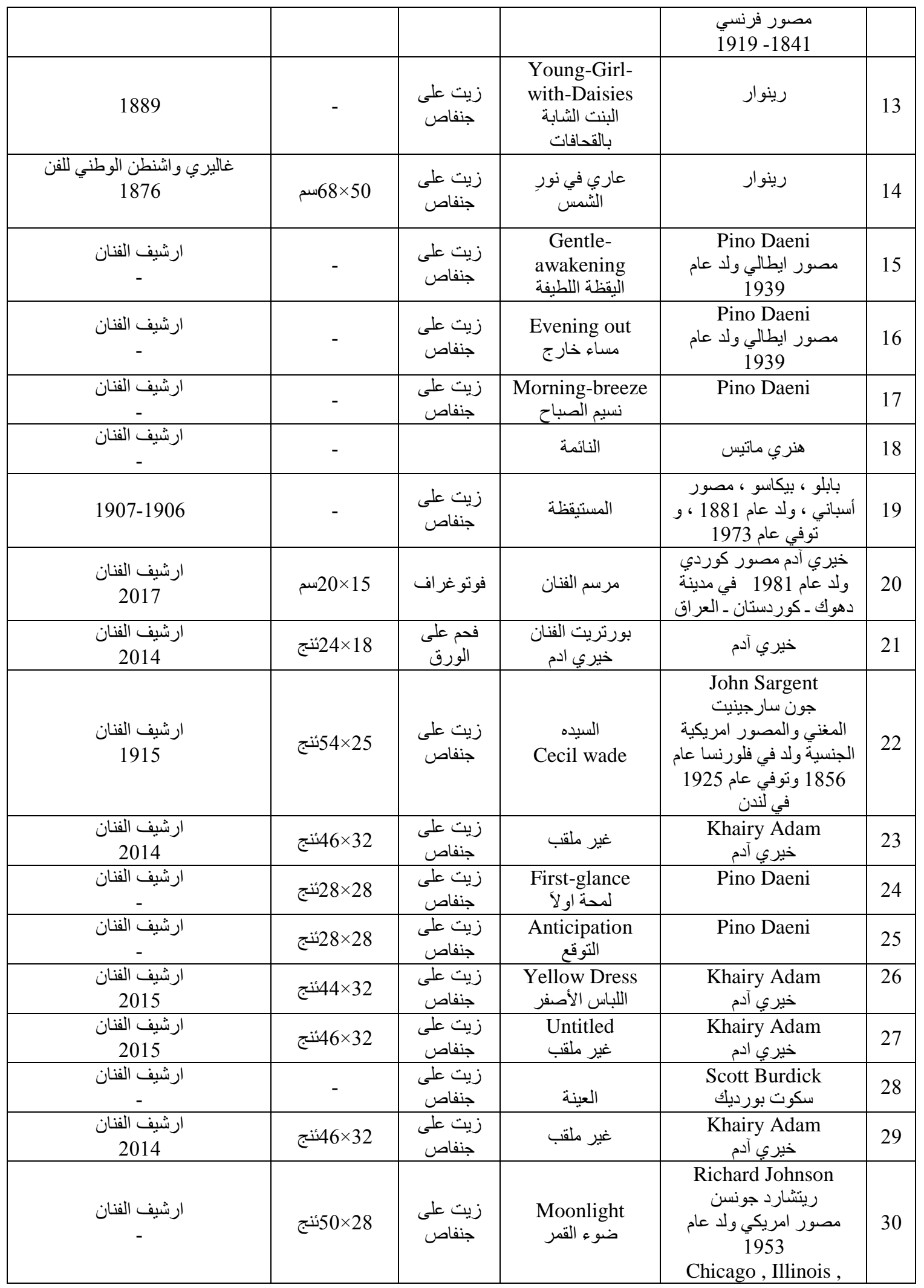




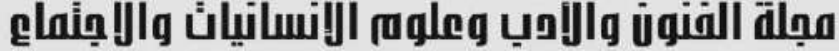

Journal of Arts, Literature, Humanities and Social Sciences www.jalhss.com

\begin{tabular}{|c|c|c|c|c|c|}
\hline & & & & United states & \\
\hline $\begin{array}{c}\text { ارشيف الفنان } \\
\text { - }\end{array}$ & 18×24ئنج & زيت على جنفاص & $\begin{array}{c}\text { Ballet Dreams } \\
\text { احلام باليهِه }\end{array}$ & ريتشارد جونسن & 31 \\
\hline ارشيف الفنان & 24×48ئنج & زيت على جنفاص & $\begin{array}{l}\text { Golden Repose } \\
\text { الراحة الذهبية }\end{array}$ & ريتشارد جونسن & 32 \\
\hline
\end{tabular}

قائمة اشكال العينات حسب ظهور تحليلهم

\begin{tabular}{|c|c|c|c|c|c|}
\hline عائديه العمل / سنة لإنجاز & القياسات & المادة & موضوع اللوحة & اسم الفنان وهويته & $ت$ \\
\hline ارشيف الفنان & ئنج×44ئنج 32 & زيت على جنى & بنت الاحلام & 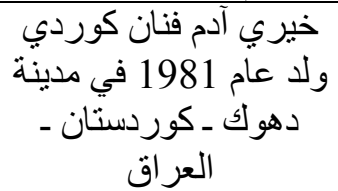 & 1 \\
\hline ارشيف الفنان & ئنج×44 32 نئج & زيت على جناص & الرسالة & نفسـا & 2 \\
\hline ارشيف الفنان & ئنج×44 32 & زيت على جنى & الانتظار & نفسـه & 3 \\
\hline كاليفورنيا & $\begin{array}{c}32 \\
46 \times ن=34\end{array}$ & زيت على جناص & الحلم & نفسـه & 4 \\
\hline
\end{tabular}

\section{المصادر و المراجع ( حسب ما جاء في المتن البحث )}

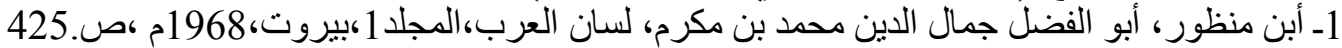
2- صلبيا ،جميل ،المعجم الفلسفي بالالفاظ العربية والفرنسية والانكليزية ،ج1 ،ط1 ،ذوبي القربى ، ب ،ت ،

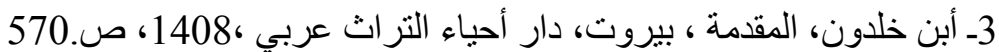

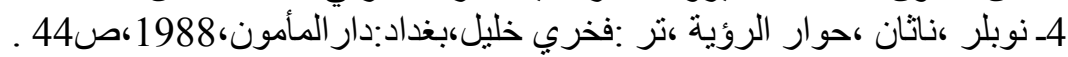
5- باونيس الآن، الفن الأوروبي الحديث كتيثر :فخري خليل ،مر :جبرا أبراهيم جبرا، بغداد : دار الحرية ، 1990

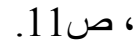
6- ريد ، هربرت، الموجز في تأريخ الرسم الحديث، تر: لمعان بكري ،مر :د. سليمان الواسطي ، بغداد

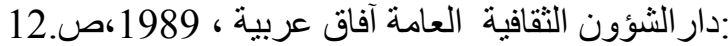

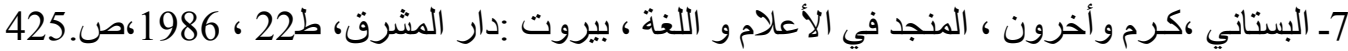

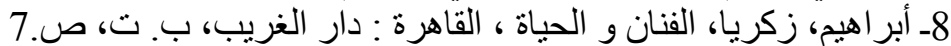
9ـ الأغا، وسماء ، الو اقعية التجريدية في الفن ، ط1، بيروت ، لبنان : المؤسسة العربية للار اسات والنشر،

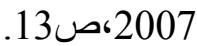
10ـ الكوفحي ، خليل محمد ،مهارات في الفنون التشكيلية ،جامعة اليرموك ، جدارا للكتاب العالمي ، ط1،

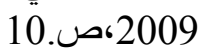

11- فارس، ، شمس الدين ، الخطاط ، سليمان عبسى ، تأريخ الفن القديم ، جامعة بغداد ، ب .ت ، ص.

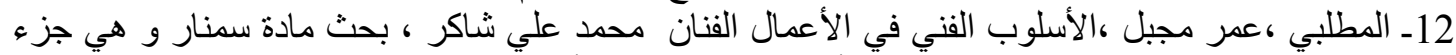

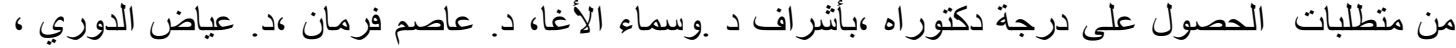

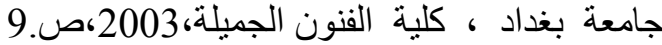
13- فيشر ، أرنست ،ضرورة الفن ، نر :أسعد حليم ، ب . م، الهيئة المصرية العامة للتأليف و النشر ، 206.صنو، 1971 14ـ لويد ، ستين ،فن شرق الادنى القديم ، نر :محمد درويش ، بغداد: دار المأمون،1988،ص.30

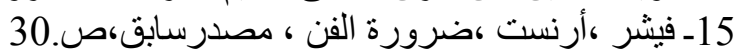




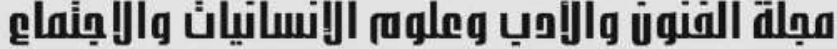

Journal of Arts, Literature, Humanities and Social Sciences www.jalhss.com

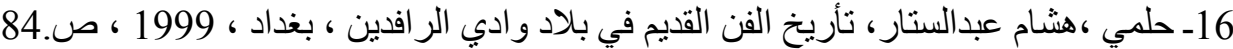

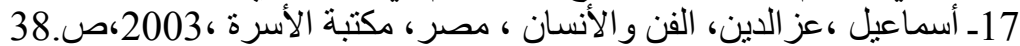

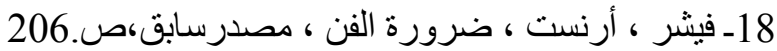

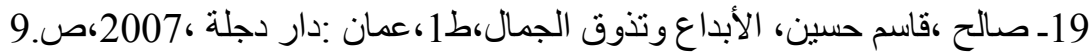

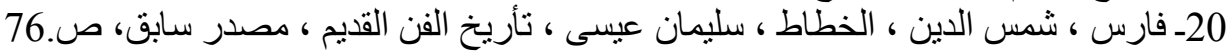

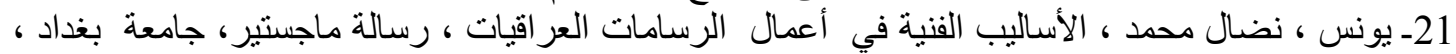
كلية الفنون

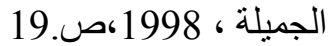

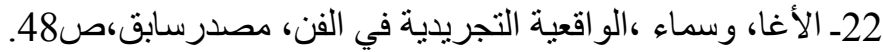

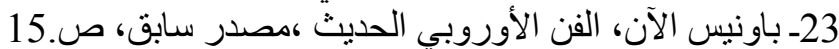

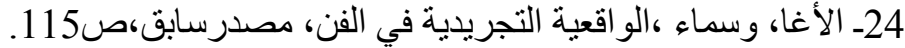

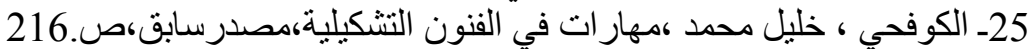

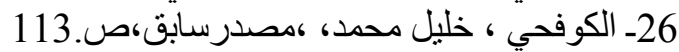

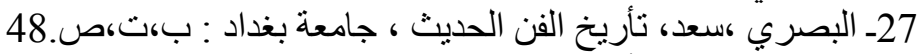

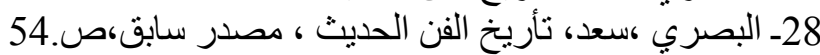

29- جان ، لُّماري ، الانطباعية ، تر : فخري خليل ، مر : جبر البراني الهيم جبر ا، بغداد : دار المأمون ، 1987، ص ص

30--Impressionism , Berenice Moryvan , Printed by Groupe Horizon , France , Paris : $2006, \mathrm{P} 112$.

$$
\begin{aligned}
& \text { 31 الكوفحي ، خليل محمد ،مهار ات في الفنون التشكيلية، مصدر سابق ،ص235. }
\end{aligned}
$$

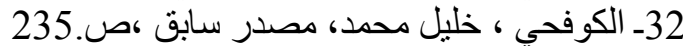

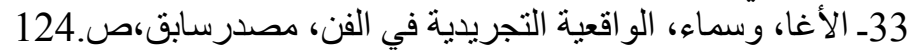

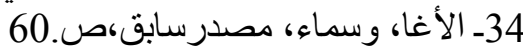

35- مولر، جي ألي ،فرانك ، ايغلر ، مئة عام من الرسم الحديث ، تر : فخري خليل ، مر : جبرا ابر اهيم جبرا ،

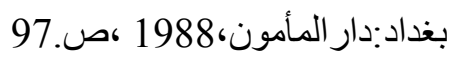

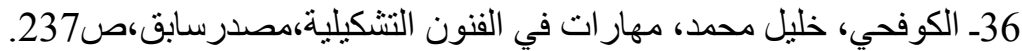

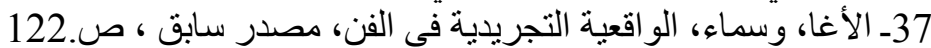

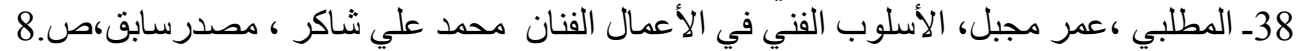

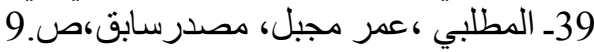

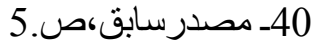

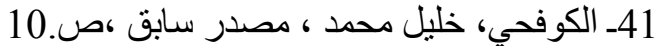

42ـ أحمد ،جنان محمد ،تطور الأسلوب الفني في الأعمال الفنان فائق حسن ،رسالة ماجستير ،كلية الفنون

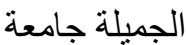

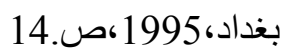

43ـ أحمد، جنان محمد ،تطور الأسلوب الفني في الأعمال الفنان فائق حسن، مصدر سابق،ص.19 الفئ

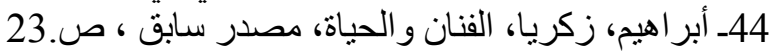

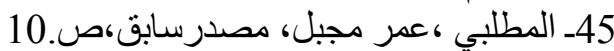

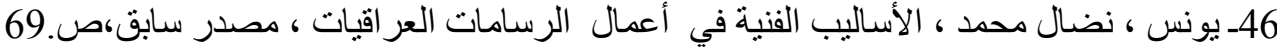

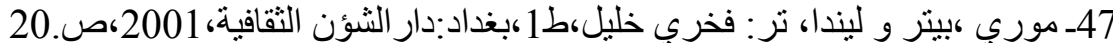

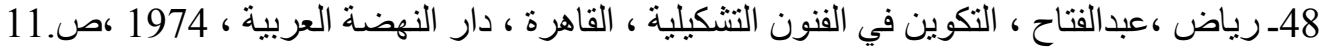

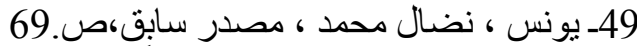

50ـ حيدر، نجم عبد، الأسلوب مفهوماً و بنيه في العملية الإبداعية ،سمنار في مادة وهي جزء من متطلبات 


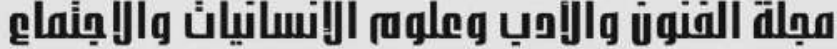

Journal of Arts, Literature, Humanities and Social Sciences www.jalhss.com

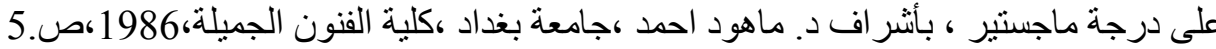

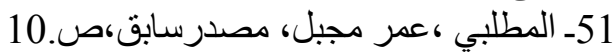

52- يونس ، نضال محمد ، الأساليب الفنية في أعمال الرسامات العر اقيات ، مصدر سابق،ص.12

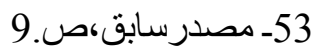

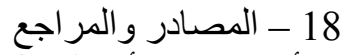

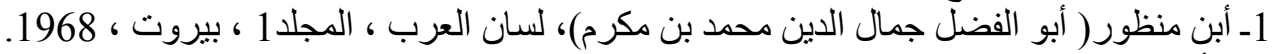

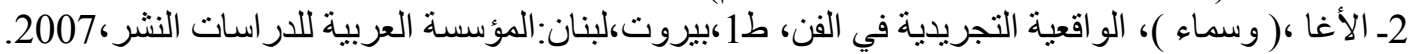

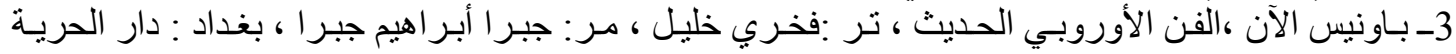

4ـ البستاني ، (كرم) و أخرون ، المنجد في الأعلام و اللغة ، بيروت : دار المشرق ، ط22 ، 1986.

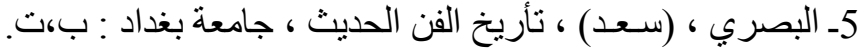

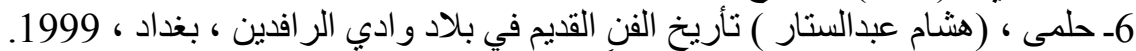

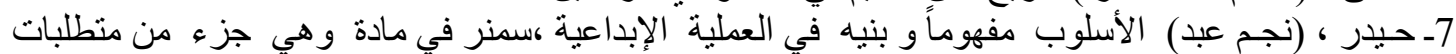
الحصول

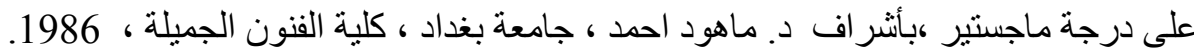

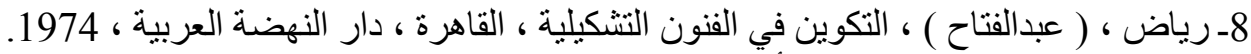

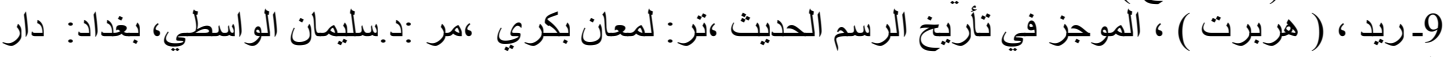
الثـؤون التقافية العامة آفاق عربية ، 1989.

10ـ صالح ، (قاسم حسين ) ، الأبداع وتذوق الجئ الجمال، ط1 ، عمان : دار دجلة ، 2007.

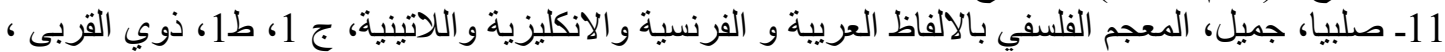

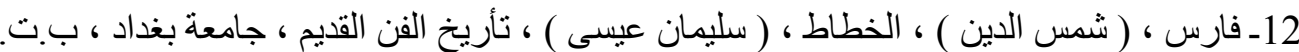

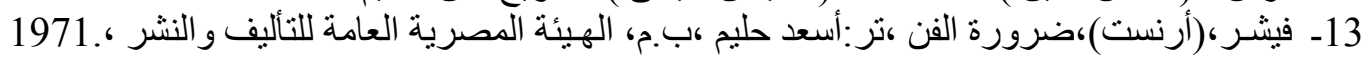

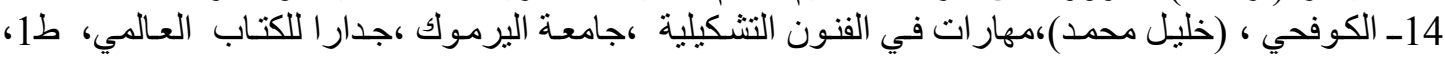

15- لويد ، ( ستين ) ، فن شرق الادنى القديم ، تر : محمد درويش ، بغداد: دار المأمون ،1988.

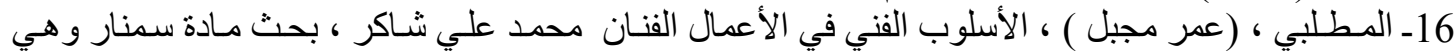

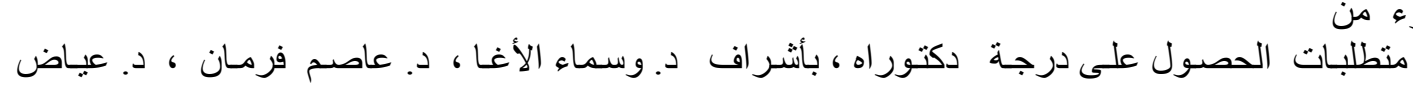

$$
\begin{aligned}
& \text { جأمعة بغداد ، كلية الفنون الجميلة ،2003. }
\end{aligned}
$$

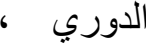

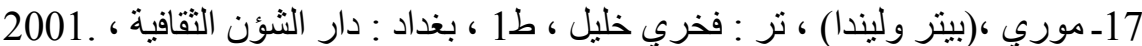

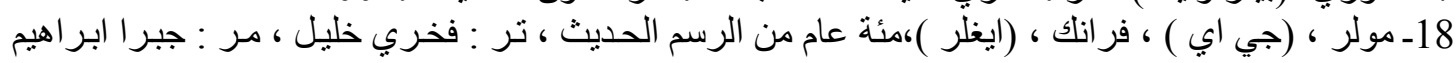

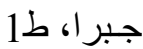

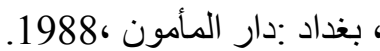

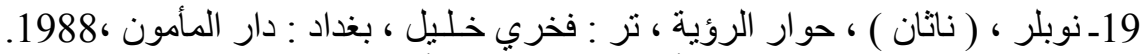

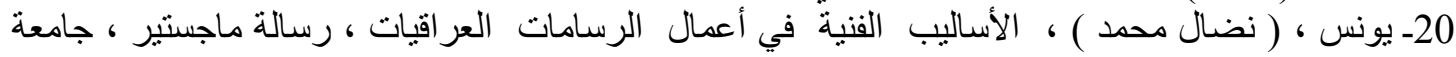

Impressionism , Berenice Moryvan , Printed by Groupe Horizon , France , Paris 21- -:2006. 